\title{
PENALIZING INSIDER TRADING: A CRITICAL ASSESSMENT OF THE INSIDER TRADING SANCTIONS ACT OF 1984
}

\author{
Carole B. Silver*
}

\section{INTRODUCTION}

The Insider Trading Sanctions Act of 1984 (the "ITSA" or the "Act") was adopted by Congress to give the Securities and Exchange Commission (the "SEC" or the "Commission") an additional weapon to use in its battle against insider trading. ${ }^{1}$ The new weapon provided by the ITSA is a treble damages sanction, which the SEC may seek to impose upon anyone found to have tipped or traded while in possession of material nonpublic information in violation of the Securities Exchange Act of 1934 (the "1934 Act"). ${ }^{2}$ The authorization of a civil penalty represents a dramatic change in the approach taken by Congress to the securities laws in general and to insider trading in particular.

Before enacting the ITSA, Congress had taken a neutral stance towards insider trading from the perspective of civil enforcement. Under the law as it existed prior to the adoption of the ITSA, the SEC could sue to enjoin future violations of the insider trading laws, to require disgorgement of any profits made from insider trading, or both. ${ }^{3}$ These enforce-

* Assistant Professor of Law, Illinois Institute of Technology, Chicago-Kent College of Law. J.D., Indiana University - Bloomington, B.A., University of Michigan. I would like to thank Lewis $M$. Collens and Michael Hyatte for their comments on the first draft of this article, and Sheldon $H$. Nahmod for his comments on a later version. I also would like to acknowledge the valuable assistance of Rochelle Miller, John Walden and Kathleen Watts in researching this article, and of Virginia C. Thomas for her aid in obtaining research material.

1. Insider Trading Sanctions Act of 1984, Pub. L. No. 98-376, 98 Stat. 1264 (1984) (the "ITSA" or the "Act"). See infra notes 42-54 and accompanying text for a general description of the Act.

2. The Securities Exchange Act of 1934, 15 U.S.C. $\$ \S 78(a)-78(I l l)$ (Supp. II 1984) [hereinafter cited as "the 1934 Act"]; see SEC to Seek Expansion of Authority to Bring Administrative Proceedings, 16 SEC. REG. \& L. REP. (BNA) 267, 268 (1984) (reporting comment of John Fedders, then Chief of Enforcement at the SEC, on the proposed ITSA: "Using fines has the advantage of making it easier for the public 'to perceive the gravity of the violation,' Fedders said. However, imposing fines would put the SEC in the 'role of a punisher,' abandoning its long-established position as a 'remedial' agency, [Fedders] added.").

3. An injunction may be sought by the Commission pursuant to section 21(d) of the 1934 Act, 15 U.S.C. $\S 78 \mathrm{u}(\mathrm{d})(1982)$.

Disgorgement may be ordered pursuant to the ancillary jurisdiction of a United States district court hearing the SEC's petition for an injunction. See Dent, Ancillary Relief in Federal Securities 
ment options did not impose a penalty for insider trading, but merely returned the defendant to the position he would have occupied had he not engaged in the illegal trade. In addition to SEC enforcement actions, the courts recognized implied private rights of action under sections $10(\mathrm{~b})^{4}$ and $14(\mathrm{e})^{5}$ and the corresponding regulations, Rules $10 \mathrm{~b}-5^{6}$ and $14 \mathrm{e}-3,7$ thereby permitting individuals injured by an illegal trade to sue for compensatory damages. ${ }^{8}$ Finally, the Justice Department could criminally prosecute a willful violation of section $10(\mathrm{~b})$ or any other section of the 1934 Act and seek to imprison the defendant, to fine him, or both.9 Prior to the adoption of the ITSA, there was no statutory authority in the securities laws for penalizing insider trading other than through criminal prosecution. The new Act shifted the focus of civil enforcement from compensation and disgorgement-both representing a relatively

Law: A Study in Federal Remedies, 67 MinN. L. Rev. 865, 930-32 (1983); Farrand, Ancillary Remedies in SEC Civil Enforcement Suits, 89 HARV. L. REv. 1779, 1800-05 (1976); Mathews, Recent Trends in SEC Requested Ancillary Relief in SEC Level Injunctive Actions, 31 Bus. LAw. 1323, 1327 (1976); Program of the Committee on Federal Regulation of Securities, SEC Civil Injunctive Actions, 30 Bus. LAw. 1303, 1305-06 (1975); Comment, Equitable Remedies in SEC Enforcement Actions, 123 U. PA. L. REv. 1188, 1194-96 (1975).

4. 15 U.S.C. § 78j(b) (1982); see Herman \& MacLean v. Huddleston, 459 U.S. 375,380 (1983) (recognizing existence of implied private right of action under section 10(b) and Rule 10b-5).

5. 15 U.S.C. § 78n(e) (1982); see Neuman v. Electronic Specialty Co., [1969-1970 Transfer Binder] FED. SEC. L. REP. (CCH) \ 92,591 (N.D. Ill. Dec. 31, 1969) (recognizing private right of action under section 14(e)).

6. 17 C.F.R. $\$ 240.10 b-5$ (1985); see supra note 4.

7. 17 C.F.R. § 240.14e-3 (1985); see O’Connor \& Assocs. v. Dean Witter Reynolds, Inc., 529 F. Supp. 1179, 1189-93 (S.D.N.Y. 1981) (plaintiff options trader could maintain action under Rule 14e-3 where corporate insiders tipped nonpublic information concerning unannounced tender offer).

8. On the measure of damages relevant in a private action under Rule $10 \mathrm{~b}-5$, see infra note 243.

9. The 1934 Act, $\S 32,15$ U.S.C. § 78ff (1982).

The ITSA increased the monetary criminal penalty under section 32 to a maximum of $\$ 100,000$. ITSA § 3, 15 U.S.C. § 78ff (Supp. II 1984). In addition, section 32 authorizes a maximum prison sentence of five years. Either the fine or imprisonment, or both, may be ordered upon conviction. See id.

In addition to criminal prosecution, the SEC has successfully sought the imposition of other sanctions that could be characterized as "penal," such as suspension or revocation of a brokerdealer's registration, 15 U.S.C. $\S 780$ (b)(5) (1982); see, e.g., Dlugash v. SEC, 373 F.2d 107, 107 (2d Cir. 1967) (revocation); Gilligan, Will \& Co. v. SEC, 267 F.2d 461, 463 (2d Cir.) (suspension), cert. denied, 361 U.S. 896 (1959); or barring a broker from association with a broker-dealer for a period of time, see, e.g., In re Paul, 32 S.E.C. 936 (Feb. 26, 1985), reprinted in [1984-1985 Transfer Binder] FED. SEC. L. REP. (CCH) $\{83,748$ (barring salesman from association with any broker or dealer for two years after he was convicted of filing false federal income tax returns). See generally H. FrIEDMAN, SeCurities AND COMmodities ENForCEMENT 55-63 (1981). Pursuant to authority in the Commission's Rule of Practice Rule 2(e), 17 C.F.R. $\S 201.2(\mathrm{e})$ (1985), the SEC has also barred lawyers and accountants who violate the Securities Act of 1933, 15 U.S.C. $\$ \S 77 a-77 a a(1982)$, or the 1934 Act from practicing before the Commission. See generally Ferrara, Administrative Disciplinary Proceedings Under Rule 2(e), 36 Bus. LAw. 1807 (1981); Marsh, Rule 2(e) Proceedings, 35 Bus. LAw. 987 (1980) (discussing specific applications of Rule 2(e)). 
neutral approach to insider trading-to penalizing the prohibited activity.

Thus, before the ITSA, an inside trader could only be penalized following criminal conviction for violation of the insider trading laws. As with all criminal prosecutions, a prosecution for a violation of the insider trading provisions of the securities laws is attended by all of the constitutional safeguards afforded any criminal defendant. ${ }^{10}$ For example, the defendant has a right to a jury trial, ${ }^{11}$ and guilt must be proven beyond a reasonable doubt. ${ }^{12}$ Moreover, the Justice Department, not the SEC, decides which criminal cases to prosecute and conducts the litigation. ${ }^{13}$ Undoubtedly because of a combination of these factors, criminal prosecutions for insider trading have been rare. ${ }^{14}$

Under the new Act, in contrast, an inside trader can be penalized under civil enforcement procedures. The SEC, not the Department of Justice, is the plaintiff in an action under the ITSA, ${ }^{15}$ and the defendant is entitled only to the procedural protections available in any civil lawsuit. 16

This civil enforcement mechanism, without the full panoply of protections offered a criminal defendant, was exactly what Congress intended in adoptimg the ITSA. ${ }^{17}$ Both Congress ${ }^{18}$ and the Commission ${ }^{19}$

10. Because a violation of section 32 can lead to a term of imprisonment of five years, see supra note 9, it is a felony. See 18 U.S.C. $\$ 1$ (1982) (defining what crimes constitute felonies).

11. U.S. CONST. amend. VII.

12. See In re Winship, 397 U.S. 358, 364 (1970).

13. 15 U.S.C. $\S 78 u(d)(1)$, (2) (Supp. II 1984).

14. See Insider Trading Sanctions and SEC Enforcement Legislation: Hearings on H.R. 559 Before the Subcomm. on Telecommunications, Consumer Protection, and Finance of the House Comm. on Energy and Commerce, 98th Cong., 1st Sess. 67 (1983) [hereinafter cited as 1983 House Hearings] (statement of Rep. Bates) ("Only six people have ever been convicted on criminal charges [of violating section 10(b) and Rule 10b-5], and one conviction was overturned."); see also Insider Trading Sanctions Act of 1983: Hearings on H.R. 559 Before the Subcomm. on Securities of the Senate Comm. on Banking, Housing, and Urban Affairs, 98th Cong., 2d Sess. 43-51 (1984) [hereinafter cited as 1984 Senate Hearings] (letter from John M. Fedders, Director of the Enforcement Division of the SEC) (synopsizing 22 cases in which criminal prosecutions were brought against inside traders as of May 1984).

15. The ITSA provides that "the Commission may bring an action . . . to seek . . . a civil penalty" when it believes that the insider trading prohibitions have been violated. ITSA $\S 3,15$ U.S.C. $\$ 78 u(d)(2)(A)$ (Supp. II 1984) (emphasis added); see infra notes 74-75 and accompanying text.

16. See infra notes 74-77 and accompanying text.

17. Congress and the Commission perceived an increase in insider trading. See discussion infra notes $32-40$ and accompanying text.

18. In introducing the ITSA to the Subcommittee on Telecommunications, Consumer Protection and Finance of the House Committee on Energy and Commerce, the Chairman of the Subcommittee, Representative Wirth, characterized its purpose as to "provide a sufficient deterrent so that people will think twice before they engage in what all of us would call thievery." 1983 House Hearings, supra note 14, at 2 . On the issue of deterrence, see infra notes 56-58 and accompanying text. 
believed that the most effective way to combat insider trading was to authorize the SEC to seek more severe sanctions in its enforcement actions. Obviously, the threat of a treble damages penalty is a more powerful deterrent than the threat of disgorgement, since the potential loss from disgorgement merely returns the violator to his pre-violation financial position. ${ }^{20}$ Accordingly, Congress determined that a penalty in addition to disgorgement was necessary to deter insider trading. Furthermore, the force of a deterrent is strongest when the likelihood of detection and prosecution is greatest. ${ }^{21}$ Congress believed that criminal safeguards and the involvement of the Department of Justice simply impeded enforcement efforts. It chose a civil sanction, instead of simply increasing the criminal penalties, $\mathrm{m}$ order to avoid the necessity of involving the Department of Justice. Moreover, civil procedural protections would permit the SEC to prosecute many more cases successfully than would criminal safeguards. The cost of prosecuting criminal cases is higher than that of civil actions, ${ }^{22}$ and the lower burden of proof applicable in civil cases permits a greater number of successful prosecutions than does the "beyond a reasonable doubt" standard of criminal cases. In enacting the ITSA, Congress provided the SEC with the strongest weapon it could fashion within the constraints of existing case law defining insider trading. ${ }^{23}$

As a civil penalty, however, the ITSA has several significant defects. First, it fails to define the prohibited conduct and instead relies on existing and developing case law to establish the boundaries of legitimate activity. ${ }^{24}$ Because the case law under sections $10(\mathrm{~b})$ and $14(\mathrm{e})$ is far

19. 1984 Senate Hearings, supra note 14, at 17 (statement of SEC Chairman Shad).

20. "Mere removal of economic benefit will usually be insufficient by itself to secure compliance with regulatory standards. It is necessary, at least in theory, to multiply the documented benefit by a factor representing the likelihood of escaping punishment altogether." Diver, The Assessment and Mitigation of Civil Money Penalties by Federal Administrative Agencies, 79 CoLum. L. REv. 1435, 1467 (1979) (footnote omitted); see also Dooley, Enforcement of Insider Trading Restrictions, 66 VA. L. REV. 1, 4 (1980) ("It is assumed that, holding other factors constant, an increase in either the probability of apprehending and punishing violators or in the magnitude of the applicable nominal sanction will result in a decreased number of violations.") (footnotes omitted).

Of course, even when the SEC seeks only disgorgement, more is at stake for the defendant than simply the amount of profit. The defendant will incur costs in defending the suit (such as attorney's fees) and may suffer a loss of reputation or employment or both as a result of the enforcement action. See 1983 House Hearings, supra note 14, at 60 (statement of SEC Chairman Shad).

21. 1983 House Hearings, supra note 14, at 268-69 (statement of Ted J. Filfis) (discussing deterrence value of the penalty).

22. The higher cost of a criminal prosecution results in part from the time required to select a jury. But see infra notes 225-38 (discussing right to jury trial under ITSA).

23. The treble damages penalty might be even more effective as a deterrent if it were made available as a sanction that the SEC could impose administratively. The Commission did not request such authority, however. See 1983 House Hearings, supra note 14, at 31-32.

24. See infra notes 83-96 and accompanying text. 
from clear or uniform, 25 a defendant may lack notice of the illegality of his conduct. This lack of notice raises concerns about due process and the retroactive application of new rules of law. ${ }^{26}$ In addition, Congress stated that the standard of proof in an action under the ITSA should be the civil standard, "a preponderance of the evidence." 27 That standard, however, may not be appropriate in light of the size of the ITSA penalty and the imprecision with which it defines the proscribed conduct. The imposition of a penalty also seems to require guaranteeing to a defendant the right to trial by jury, yet the Act is silent on this issue. Finally, the sanction authorized by the ITSA is not exclusive but may be imposed in addition to other remedies accorded the SEC or private litigants. Congress did not indicate whether there was a maximum sanction that any one defendant should suffer as a result of insider trading. These issues will be discussed in the following sections, which analyze the provisions of the Act.

After elaborating the troublesome features of the ITSA as a civil penalty provision, the article considers whether the ITSA should have been drafted as a criminal provision or could be judicially construed as one. The treatment of the Act as a criminal statute, however, poses additional concerns, especially about the efficacy of regulating economic conduct through the criminal laws. The article concludes with guidelines for courts and the Commission to use in applying the treble damages penalty, aimed at remedying the probleins underlying the ITSA as enacted. These guidelines address when the Commission should invoke the ITSA $^{28}$ and how courts ought to determine the amount of the penalty imposed under the Act; ${ }^{29}$ they also propose certain procedural protections, such as an intermediate standard of proof and the right to trial by jury, ${ }^{30}$ that should be afforded defendants when the SEC seeks treble dainages under the Act.

\section{DESCRIPTION AND ANALYSIS OF THE ITSA}

\section{A. Adoption of the ITSA.}

The SEC initiated consideration of the ITSA ${ }^{31}$ as part of its in-

\footnotetext{
25. See infra notes 97-140 and accompanying text.

26. See infra notes $157-89$ and accompanying text.

27. See infra notes $190-95$ and accompanying text.

28. See infra notes 274-87 and accompanying text.

29. See infra notes $288-94$ and accompanying text.

30. See infra notes $295-97$ and accompanying text.

31. See letter from SEC Chairman Shad to House Speaker Thomas P. O'Neill, Jr. (Sept. 27, 1982), reprinted in H.R. REP. No. 355, 98th Cong., 2d Sess. 19-27 (1983), reprinted in 1984 U.S. CODE CONG. \& AD. NEws 2274, 2292-99 [hereinafter cited as House REPORT]. For a description of the Act, see infra notes $66-80$ and accompanying text; Langevoort, The Insider Trading Sanctions
} 
creased enforcement activity against insider trading. ${ }^{32}$ This increase in enforcement was proinpted by the Cominission's belief that the opportunities for gains from trading on the basis of material nonpublic information have expanded in recent years. ${ }^{33}$ The increased profitability of insider trading arises froin two trends in business and finance.

First, the recent spate of tender offers and other business combinations ${ }^{34}$ has broadened the opportunities for gain from trading on the basis of material nonpublic information. If a person knows of an impending acquisition, he can reap huge profits by trading in the securities of the company about to be acquired before the acquisition is publicly announced. ${ }^{35}$ As acquisitions increase, so do opportunities to gain froin trading on the basis of knowledge of such acquisitions.

The second trend is the growth of the market for financial options on securities. ${ }^{36}$ Options trading may yield significant profits, while the investor risks only the price of the option, usually a small fraction of the price of the underlying securities. ${ }^{37}$ For this reason, trading in options is more attractive than trading in securities for persons who do not want to invest the aggregate price of the securities. ${ }^{38}$ The options market thus

Act of 1984 and Its Effect on Existing Law, 37 VAND. L. REv. 1273, 1276-77 (1984); Note, A Critique of the Insider Trading Sanctions Act of 1984, 71 VA. L. REv. 455 (1985).

32. 1983 House Hearings, supra note 14, at 18 (statement of SEC Chairman Shad) ("In order to curtail and deter insider trading, the Commission has sharply increased the number of enforcement actions against such conduct."); see also id. at 21-22. The ITSA was intended by Congress only to provide a new remedy; it was not intended to affect the substantive law of insider trading. See 1983 House Hearings, supra note 14, at 50.

33. See generally 1983 House Hearings, supra note 14, at 16-27 (prepared statement of SEC Chairman Shad).

34. See 1984 Senate Hearings, supra note 14, at 11-12, 17 (statement of SEC Chairman Shad); 1983 House Hearings, supra note 14, at 19 (statement of SEC Chairman Shad); 130 CONG. REC. H7759 (daily ed. July 25, 1984) (statement of Rep. Wirth); see also Thomas, Insider Trading Revisited: The SEC's New Initiatives, 1982-1983 CORP. PRAC. COMM. 435, 435 ("The current wave of mergers and tender offers provides the green fertilizer that makes [insider trading] thrive.").

35. See, e.g., Bleiberg, Want a Hot Tip? There's No Way to Prevent Trading on Insider Information, 61 BARRONS 7 (1981); Louis, The Unwinnable War on Insider Trading, 104 FORTUNE $72-76$ (1981).

36. See, e.g., 1983 House Hearings, supra note 14, at 17-19 (statement of SEC Chairman Shad) (discussing adverse effects of insider trading in options on market makers and specialists); 130 CoNG. REC. $\mathbf{H} 7759$ (daily ed. July 25, 1984) (statement of Rep. Wirth). See generally CoMmodiTY Futures Trading Commission, a Study of the NatURe, Extent and Effects of Futures Trading by Persons Possessing Material Nonpublic InFormation, summarized in 1984 COMMODitY FUtURES TRADING COMm'N ANN. REP. 60-64 [hereinafter cited as CTFC STUDY]. On April 16, 1985, the SEC agreed in principle to permit the trading of options on securities traded in the over-the-counter market. See SEC Approves Multiple Trading of OTC Options by NASD, Exchanges, 17 SEC. REG. \& L. REP. (BNA) 647 (1985).

37. See generally Gastineau, The Stock Options Manual (2d ed. 1979).

38. However, pursuant to Regulation T, 12 C.F.R. $\$ 220$ (1985), and Regulation U, 12 C.F.R. $\S 221$ (1985), many securities can be traded through use of a margin account, which requires only 
opens up the field to new players. ${ }^{39}$ Moreover, when material nonpublic information is announced, the value of an option contract may increase at a greater rate than the value of the underlying securities. ${ }^{40}$ Thus, trading in options on inside information might yield greater gains more quickly than trading in the underlying securities on the basis of that information.

Two general concerns provided the incentive for the adoption of the ITSA as the remedy for the insider trading problem. First, the SEC believed and persuaded Congress that the available sanctions were inadequate to provide sufficient deterrence against violations of the law prohibiting insider trading. ${ }^{41}$ Prior to the adoption of the Act, the SEC had two remedies available to it. It could seek an injunction against future violations of the relevant statute or regulation, and it could require the defendant to disgorge any profit realized or loss avoided by the illegal trade. ${ }^{42}$ According to the SEC, these sanctions (and any other consequences of a charge of insider trading) merely put the defendant back in the position he would have occupied had he not violated the law in the first place. ${ }^{43}$ Any profits derived from the illegal trade would be paid back, and the defendant would be formally prohibited from violating the law in the future. In the Commission's view, then, one could not lose from insider trading. ${ }^{44}$

$50 \%$ of the current market value of the security to be maintained in the margin account for each security held by such account. 12 C.F.R. $\$ 220.18$ (a) (1985).

39. See CTFC STUDY, supra note 36 , at 61-63 (discussing trading abuses unique to trading in options and futures).

40. 1983 House Hearings, supra note 14, at 20 (statement of SEC Chairman Shad). See generally Note, supra note 31 , at 466 \& n.77.

The greater gain on an option from the announcement of material information might occur as a result of the new information increasing the uncertainty about the potential of the issuer. Increased uncertainty will increase the value of an option because the potential gains are greater.

41. 1984 Senate Hearings, supra note 14, at 20 (statement of SEC Chairman Shad) ("[T]he recent conjunction of tender offers and acquisitions with the availability of trading in standardized options contracts . . . have fundamentally altered the risk-reward equation with respect to insider trading and demonstrate the need for a new enforcement remedy to deter such conduct.").

42. See supra note 3.

43. The SEC has recognized that the consequences of a successful enforcement action may go beyond disgorgement: "[I]t should be noted that defendants may also be subject to criminal prosecution by the Justice Department, imprisonment and criminal fines, civil suits by defrauded parties, disbarment, license revocation, and other proceedings by professional and self-regulatory organizations, the loss of employment, legal fees, and social opprobria." 1983 House Hearings, supra note 14, at 14 (statement of SEC Chairman Shad); see also 1983 House Hearings, supra note 14, at 26-27, 60, 133, 238; Thomas, supra note 34, at 438 ("Indeed, when professionals [lawyers, accountants and securities professionals] are involved, we're going to hit them where it hurtsi their professional standings."). The SEC can also use Rule 2(e) of the Commission's Rules of Practice to prohibit professionals from appearing before the Commission. See supra note 9.

44. See 1983 House Hearings, supra note 14, at 2; see also Diver, supra note 20, at 1463-64 (discussing use of penalties to deter illegal conduct); Goldschmid, An Evaluation of the Present and 
The second major incentive for the adoption of the Act was Congress's and the SEC's dissatisfaction with the substantive law governing insider trading. ${ }^{45}$ In the early 1980's, the Supreme Court issued two significant insider trading decisions. ${ }^{46}$ Both cases narrowly construed the applicability of section 10(b) and Rule 10b-5 to "outsiders"-persons who were not officers, directors, or otherwise traditional insiders with respect to the issuer of the traded securities-who traded on the basis of material nonpublic information or tipped such information to one who then traded in the security. In Chiarella v. United States ${ }^{47}$ and Dirks $v$. $S E C, 48$ the Court emphasized that section 10(b) and Rule 10b-5 prohibit only fraud in connection with the purchase and sale of securities and that violations occur only when there has been a breach of duty amounting to fraud.

Chiarella was an employee of a financial printer that was hired to prepare the acquisition documents for five corporate takeover bids. ${ }^{49}$ Chiarella's employer was hired by the acquiring company in each of the five transactions..$^{50}$ Although the target company name was not disclosed in any of the five documents, Chiarella discovered the identities of the targets from information contained in the bidder's documents and bought stock in the targets before the tender offers were announced.51 When the acquisitions were announced to the public, the price of the target stock rose, and Chiarella profited by selling his shares at the higher market price. ${ }^{52}$ The Justice Department brought a criminal action against Chiarella for violation of section 10(b) and Rule 10b-5.53

The Supreme Court held that Chiarella's actions should be considered fraudulent only if the government could show that he was under a duty not to use the information for his personal gain while it was unavailable to the public. ${ }^{54}$ The Court held that such a duty to refrain from

Potential Use of Civil Money Penalties as a Sanction by Federal Administrative Agencies, in 2 RecomMENDATIONS AND REPORTS OF THE ADMINISTRATIVE CONFERENCE OF THE UNITED STATES 896, 934 (1972) (recommending use of civil monetary penalties in 10b-5 cases to deter defendants); Note, supra note 31 , at $488-91$ (arguing that increased enforcement is also necessary to deter insider trading).

45. See infra note 63 and accompanying text.

46. Dirks v. SEC, 463 U.S. 646 (1983); Chiarella v. United States, 445 U.S. 222 (1980).

47. 445 U.S. 222 (1980).

48. 463 U.S. 646 (1983).

49. Chiarella, 445 U.S. at 224.

50. Id. at 235 .

51. Id. at 224 .

52. Id.

53. Id. at 225.

54. "Section 10(b) is aptly described as a catch-all provision, but what it catches must be fraud. When an allegation of fraud is based upon nondisclosure, there can be no fraud absent a duty to speak." Id. at 234-35. 
trading on the basis of material nonpublic information arises, if at all, as a result of the defendant's relationship to the stockholders of the corporation in whose securities the defendant traded, ${ }^{55}$ and that, generally, only a fiduciary relationship between the defendant and other traders in the same securities creates such a duty. ${ }^{56}$ Therefore, even though Chiarella had used material nonpublic information to his personal benefit, his trading did not violate section 10(b) or Rule 10b-5 because he had no relationship to the stockholders of the target companies in whose securities he had traded, and so owed those investors no duty to refrain from trading on the basis of the material nonpublic information he had discovered.

In Dirks, the Court clarified under what circumstances the communication of material nonpublic information, "tipping," constitutes a fraudulent breach of duty to the stockholders of the corporation in whose securities a trade is made. ${ }^{57}$ It held that an insider who tips information to another person breaches a duty owed to the shareholders only if the purpose of the tip is to gain some personal benefit in exchange for the information communicated. 58 The Court also held that the tippee's duty to refrain from using such information derives from the tipper's breach of duty. ${ }^{59}$ If communication of the information by the tipper is not a breach of duty, then the tippee's use of such information in a trade does not violate the federal securities laws in the absence of a separate, special

55. "Thus, administrative and judicial interpretations have established that silence in connection with the purchase or sale of securities may operate as a fraud actionable under $\S 10(\mathrm{~b}) \ldots$ But such liability is premised upon a duty to disclose arising from a relationship of trust and confdence between the parties to a transaction." Id. at 230 .

56. "[T]he duty to disclose arises when one party has information that the other [party] is entitled to know because of a fiduciary or other similar relation of trust and confidence between them." Id. at 228 (footnote omitted) (quoting RESTATEMENT (SECOND) OF TORTS $\S 551(2)(\mathrm{a})$ (1976)).

57. Dirks was an officer of a broker-dealer firm; he specialized in providing investment analyses of insurance company stocks to institutional investors. Dirks, 463 U.S. at 648 . In that connection, Dirks received material nonpublic information from Secrist, a former employee of Equity Funding of America ("Equity Funding"), an insurance holding company whose stock was traded on the New York Stock Exchange. Id. at 648-49 (citing statement of facts in Dirks v. SEC, 681 F.2d 824, 829-30 (D.C. Cir. 1982)). Secrist told Dirks that the assets of Equity Funding were overstated as a result of the company's fraudulent practices. Id. at 649.

Neither Dirks nor his firm traded in Equity Funding stock. Id. Dirks, however, investigated the allegations and discussed the material nonpublic information he had gathered with clients and investors, some of whom sold their stock in Equity Funding. Id. Nevertheless, the Court held that Dirks was not liable under Rule 10b-5. Id. at 665 . In so holding, the Court limited a tippee's potential for derivative liability to those situations where the tipper violated his duty to the corporation. Secrist, the tipper, did not breach such a duty. In the absence of such a breach, the tippee, Dirks, could not be derivatively liable under Rule 10b-5. Id. at 659-67.

58. Id. at 663-64.

59. Id. at $661-62,664$. 
relationship between the tippee-trader and the corporation. ${ }^{60}$

In Chiarella and Dirks, the Supreme Court narrowly interpreted the scope of activities proscribed by section 10(b) and Rule 10b-5. The decisions leave trading or tipping on the basis of material nonpublic information unregulated when that trading or tipping does not violate a duty owed to an issuer or investor by virtue of a special relationship. ${ }^{61}$ In Chiarella no violation occurred because the defendant-trader owed no duty to the issuer or investors in the securities in which the defendant traded. In Dirks no violation occurred because the defendant-tippee's conduct could not be traced to breach of a duty by the tipper. ${ }^{62}$ Congress and the SEC have expressed dissatisfaction with these holdings, which permit some persons to profit legally by trading on the basis of material nonpublic information. ${ }^{63}$ Although the specific problem of insider trading found in Chiarella is now regulated by Rule $14 \mathrm{e}-3$ of the 1934 Act, ${ }^{64}$ Congress's disenchantment with the substantive law of insider trading added to the impetus for the adoption of the ITSA. ${ }^{65}$

60. Id, at 659-61.

61. But see infra notes 100-26 and accompanying text (discussing misappropriation theory); see also Dirks, 463 U.S. at $654 \mathrm{n} .14$ (discussing "temporary insider" theory, by which a duty to refrain from using material nonpublic information derived from client may be imposed on attorney, accountant or other professional who acts as temporary insider to the issuer).

62. Dirks, 463 U.S. at 665-67.

63. HOUSE REPORT, supra note 31, at 22 (indicating an expansive view of Chiarella); A.B.A. Committee on Federal Regulation of Securities, Section of Corporation, Banking and Business Law, Report of the Task Force on Regulation of Insider Trading, Part I: Regulation Under the Antifraud Provisions of the Securities Exchange Act of 1934, 41 Bus. LAw. 223, 235 (1985) [hereinafter cited as $A B A$ Task Force Report]; see also Thomas, supra note 34, at 442 (discussing SEC's consideration of a substantive amendment of Rule 10b-5 and section 10(b)).

64. 17 C.F.R. § 240.14e-3 (1984); see Loewenstein, Section 14(e) of the Williams Act and the Rule 10b-5 Comparisons, 71 Geo. L.J. 1311, 1352-56 (1983).

65. See infra notes 100-26 and accompanying text (discussing misappropriation theory, an alternative theory for liability under Rule 10b-5 after Chiarella).

In proposing and adopting the ITSA, however, both the SEC and Congress acted without the benefit of a rigorous debate about the basic question whether insider trading should be prohibited at all. The SEC wanted the additional enforcement weapon of treble damages and wanted it quickly. See 1983 House Hearings, supra note 14, at 3, 12, 53, 230. The Commission succeeded in obtaining quick action from Congress by taking what it believed to be the least controversial position on each of the issues raised by commentators and members of Congress. In the end, the Act was almost unopposed in Congress, see 130 CoNG. Rf.c. H7756-60 (daily ed. July 25, 1984); id. at S8911-14 (daily ed. June 29, 1984); 129 Cong. Rec. H7011-13 (daily ed. Sept. 18, 1983); the only signifficant disagreement came from those who wanted the new statute to change existing substantive law to bring nonfraudulent conduct within its reach, see 1983 House Hearings, supra note 14, at 231. Yet there still exists significant controversy not only about how to punish insider trading, but also about whether it should be prohibited at all. See, e.g., authorities cited infra note 267; 1983 House Hearings, supra note 14, at 34-36 (exchange between John Fedders and Rep. Wirth about whether insider trading is a "victimless crime"). 


\section{B. General Description of the ITSA.}

The heart of the new Act is the definition of the activity that creates liability for treble damages. The treble damages provision is triggered whenever "any person has violated any provision [of the 1934 Act] . . . by purchasing or selling a security while in possession of material nonpublic information."66 Thus, the ITSA is tied to the existing antifraud provisions of the 1934 Act that govern insider trading-sections 10(b) and 14(e), and Rules 10b-5 and 14e-3-and relies on a violation of these provisions for its applicability.

The jurisdictional requirements of the ITSA, however, make it slightly narrower in scope than section 10(b) and Rules 10b-5 and 14e-3. It applies only to trades that are executed on a national securities exchange or through a broker or a dealer. ${ }^{67}$ In contrast, section $10(\mathrm{~b})$ requires for jurisdictional purposes only "the use of any means or instrumentality of interstate commerce or of the mails, or of any facility of any national securities exchange."68 The jurisdictional scope of Rules $10 \mathrm{~b}-5$ and $14 \mathrm{e}-3$ is substantially similar to that of section 10(b). ${ }^{69}$ Thus, not every violation of section 10(b) and Rule 10b-5 or Rule 14e-3 allows the SEC to seek treble damages under the ITSA.

Furthermore, the ITSA does not apply to persons who have aided and abetted a violation of the insider trading laws, ${ }^{70}$ nor will the treble

66. ITSA § 2, 15 U.S.C. $\$ 78 u(d)(2)(A)$ (Supp. II 1984). In addition, the provision limits the applicability of the Act to trades that occur on a national securities exchange and are not part of a public offering of securities by an issuer. See infra notes 67-69 (discussing jurisdictional scope of ITSA).

Imposition of the treble damages remedy does not depend upon the court's willingness to enjoin the defendant from future violations of the law. See Stevenson, The Insider Trading Sanctions Act: Some Unfinished Business Ahead, Nat'I L.J., Oct. 15, 1984, at 18, col. 1.

67. The Act applies to insider trading that occurs in a "transaction (i) on or through the facilities of a national securities exchange or from or through a broker or dealer, and (ii) which is not part of a public offering by an issuer of securities other than standardized options." ITSA § 2, 15 U.S.C. $\S 78 u(d)(2)(A)$ (Supp. II 1984). The Act excludes public offerings by an issuer probably because there was little evidence that insider trading occurred in such circumstances.

68. 15 U.S.C. $\& 78 \mathrm{j}(\mathrm{b})(1982)$.

69. The jurisdictional scope of Rule 10b-5 is essentially identical to that of section 10(b). Rule $14 e-3$ is limited by the jurisdictional requirements of section 14(e), pursuant to which the Rule was promulgated. Although section 14(e) does not explicitly state its jurisdictional scope, it is presumed to be limited to conduct that includes use of the mails or interstate commerce. See L. Loss, FUNDAMENTALS OF SECURITIES REgULATION 574-75 \& n.23 (1983).

70. The Supreme Court has left open the issue whether liability under section $10(\mathrm{~b})$ and Rule $10 \mathrm{~b}-5$ can be premised upon a theory of aiding and abetting a violation of the securities laws. Herman \& MacLean v. Huddleston, 459 U.S. 375, 379 n.5 (1983); Ernst \& Ernst v. Hochfelder, 425 U.S. 185, $191 \mathrm{n.7}$ (1976). In the hearings on the ITSA, however, one member of Congress indicated his approval of the aiding and abetting theory of liability. 1983 House Hearings, supra note 14, at 47 (comments of Rep. Rinaldo). Several federal courts of appeals have also endorsed the theory. See. e.g., Cleary v. Perfectune, Inc., 700 F.2d 774, 777 (1st Cir. 1983) (liability for aiding and abetting a violation of section 10 (b) premised upon finding that: (1) section $10(\mathrm{~b})$ was violated by the conduet 
damages penalty be assessed against one who might be held vicariously liable for the violation. ${ }^{71}$ Thus, the Act does not apply to all persons who might be held liable in an SEC enforcement action for violation of the insider trading laws. It is available only against persons directly and intimately involved in wrongdoing: tippers of material nonpublic information, as well as persons who trade on such imformation. ${ }^{72}$ No conduct other than tipping and trading will subject a person to liability under the ITSA. The treble damages sanction is thus saved for those whose conduct directly undermines the integrity of the securities markets. ${ }^{73}$

of the primary party; (2) defendant aider and abetter had "general awareness that his role was part of overall activity that is improper"; and (3) there was "knowing and substantial assistance of the primary violation by the defendant") (citations omitted); Rolf v. Blyth, Eastman Dillon \& Co., 570 F.2d 38, 44 (2d Cir.), cert. denied, 439 U.S. 1039 (1978); Hochfelder v. Midwest Stock Exchange, 503 F.2d 364, 374 (7th Cir.), cert. denied, 419 U.S. 875 (1974). See generally Fischel, Secondary Liability Under Section 10(b) of the Securities Act of 1934, 69 CALIF. L. REV. 80 (1981); Ruder, Multiple Defendants in Securities Law Fraud Cases: Aiding and Abetting, Conspiracy, In Pari Delicto, Indemnification, and Contribution, 120 U. PA. L. REV. 597 (1972).

71. Liability under the common law doctrine of respondeat superior can be imposed on employers for conduct of their employees which violates the federal securities laws so long as such conduct is done within the scope of employment. Several circuits have imposed liability for federal securities laws violations on employers solely on the basis of respondeat superior. See, e.g., Henricksen v. Henricksen, 640 F.2d 880, 887 (7th Cir.), cert. denied, 454 U.S. 1097 (1981); Paul F. Newton \& Co. v. Texas Commerce Bank, 630 F.2d 1111, 1118 (5th Cir. 1980) (endorsing the theory of respondeat superior; case remanded for resolution of certain factual issues); Marbury Management, Inc. v. Kohn, 629 F.2d 705, 712-13 (2d Cir.), cert. denied, 449 U.S. 1011 (1980). On the other hand, some courts have rejected the theory of respondeat superior because of its apparent conflict with section 20(a) of the 1934 Act, which imposes liability upon controlling persons for securities laws violations by persons under their control unless the controlling person shows that he "acted in good faith and did not directly or indirectly induce the act or acts constituting the violation or cause of action." 15 U.S.C. $\$ 78 \mathrm{t}(\mathrm{a})$ (1982). Since liability under the doctrine of respondeat superior is broader than that under section 20(a), which does not extend to good faith conduct, these courts find that section 20(a) supplanted the doctrine of respondeat superior in federal securities laws. See, e.g., Carpenter v. Harris, Upham \& Co., 594 F.2d 388, 394 (4th Cir.), cert. denied, 444 U.S. 868 (1979); Zweig v. Hearst Corp., 521 F.2d 1129, 1132-33 (9th Cir.), cert. denied, 423 U.S. 1025 (1975).

The Supreme Court has not decided whether the doctrine of respondeat superior coexists with section 20(a) of the 1934 Act and a similar provision, section 15, of the Securities Act of 1933, 15 U.S.C. $\$ 77 o$ (1982). In hearings on the ITSA, one member of Congress indicated approval of the use of the respondeat superior theory of liability in securities law cases. See 1983 House Hearings, supra note 14, at 47-48 (comments of Rep. Rinaldo). See generally Ellis, Fairness and Efficiency in the Law of Punitive Damages, 56 S. CAL. L. REV. 1, 63 (1983); Fischel, supra note 70; Fitzpatrick \& Carmen, Respondeat Superior and the Federal Securities Laws: A Round Peg in a Square Hole, 12 HOFSTRA L. REV. 1 (1983).

72. Section 21(d)(2)(B) of the 1934 Act as amended by the ITSA provides: "No person shall be subject to a sanction under subparagraph (A) of this paragraph solely because that person aided and abetted a transaction covered by such subparagraph in a manner other than by communicating material nonpublic information." 15 U.S.C. $\$ 78 u(d)(2)(B)$ (Supp. II 1984) (emphasis added).

73. See 130 CONG. REC. S8911-13 (daily ed. June 29, 1984) (statement of Sen. D'Amato).

The ITSA contains a five-year statute of limitations for actions in which treble damages are sought. ITSA § 2, 15 U.S.C. $\S 78$ u(d)(2)(D) (Supp. II 1984). The five-year limitations period will not apply to SEC actions for injunctive relief or disgorgement, or to private actions under section 10(b) or Rules $10 \mathrm{~b}-5$ or 14e-3. SEC actions for injunctive relief are not subject to any statute of 
The ITSA creates a civil penalty for violation of the insider trading laws. Although Congress did not specifically label the Act a civil statute, there are clear indications that Congress intended the ITSA's treble damages penalty to be a civil rather than a criminal sanction. ${ }^{74}$ First, Congress placed the treble damages provision of the ITSA in an amendment to section 21 of the 1934 Act, which deals exclusively with the Commission's authorized activities and remedies. ${ }^{75}$ The fact that the ITSA was included as an amendment to section 21 indicates that it, like the rest of section 21, relates to the powers and authority of the Commission. Since the SEC is not authorized to prosecute criminal cases, ${ }^{76}$ if Congress had intended the ITSA to create a criminal sanction, placement of the Act in section 21 would have been inappropriate. Furthermore, Congress's purpose of broadening the SEC's enforcement power would not have been served by making the ITSA a criminal statute, because only the Attorney

limitations; the equitable doctrine of laches governs the length of time during which the suit may be brought. For private actions, the limitations period is determined by the law of the state in which the action is brought. See 1983 House Hearings, supra note 14, at 46. See generally L. Loss, supra note 69 , at $1166-67$.

The ITSA accomplished other amendments to the 1934 Act outside the parameters of the treble damages sanction in section 21(d). Congress amended section 32(a), 15 U.S.C. $\$ 78 \mathrm{fI}(\mathrm{a})$, to increase the maximum fine payable upon conviction of a criminal violation of the 1934 Act to $\$ 100,000$. ITSA § 3, Pub. L. No. 98-376, 98 Stat. 1265 (1984). In addition, section 15(c)(4), 15 U.S.C. $\S 78 \mathrm{o}(\mathrm{c})(4)$, was amended to add section 14 to the list of provisions a violation of which may trigger the Commission's action. Id. $\S 4$. Moreover, section 15(c)(4), 15 U.S.C. $\$ 780(\mathrm{c})(4)$, now authorizes the SEC to order compliance of a person who fails to comply with sections $12,13,14$ or subsection (d) of section 15 as well as "any person who was a cause of the failure" to comply with those provisions. Id. Dan Goelzer, General Counsel of the SEC, said that he expects the Commission to use section $15(c)(4)$ as a basis for barring repeat offenders from serving as officers and directors of publicly held corporations, as an ancillary remedy in an SEC enforcement action. Goelzer also indicated that he thought section 15(c)(4) gave the Commission the power to order such disassociation administratively, without resort to a court. See SEC to Step Up Attempts to Bar Persots From Corporate Office, Goelzer Says, 16 SEc. REG. \& L. REP. (BNA) 1825-26 (1984).

Finally, section 20,15 U.S.C. $\S 78 \mathrm{t}(\mathrm{d})$, was amended to reach traders in options on securities, and it specifies that trading in options on securities on the basis of material nonpublic information violates an obligation to investors in the underlying securities to the same extent as if the trading on nonpublic information were in the underlying securities themselves. ITSA $\S 5$, Pub. L. No. 98-376, 98 Stat. 1265 (1984); cf. Laventhall v. General Dynamics Corp., 704 F.2d 407, 413 (8th Cir.) (plailltiff option holder lacked standing under Rule 10b-5 to sue General Dynamics for latter's trading in its common stock on the basis of material nonpublic information), cert. denied, 464 U.S. 846 (1983).

74. See 1983 House Hearings, supra note 14, at 27 (statement of SEC Chairman Shad) (ITSA creates a Commission civil enforcement remedy, like disgorgement and injunctive relief); Thomas, supra note 34, at 443-44. But see Reagan Signs Insider Trading Bill with Treble Damages, No Definitionl, 16 SEC. REG. \& L. REP. (BNA) 1383 (1984).

75. Section 21 of the 1934 Act also authorizes the Commission to conduct investigations of securities laws violations and empowers members of the SEC to subpoena witnesses to obtain evidence as part of such investigations. 15 U.S.C. $\$ 78 \mathrm{u}(\mathrm{a})$, (h) (1982).

76. The 1934 Act, $\S 21$ (d)(1), 15 U.S.C. $\S 78 u$ (d)(1) (Supp. II 1984) (Commission empowered to seek only injunctive relief; may refer violations to Attorney General, who may institute criminal proceedings). 
General can bring criminal prosecutions for securities laws violations. ${ }^{77}$ If the ITSA had been enacted as a criminal statute, it would not have improved the Commission's ability to battle the insider trading problem.

It is also clear that Congress intended the treble damages penalty to be available only to the SEC in enforcement actions, and not to private litigants. First, placement of the Act in section 21 indicates this intent to augment only the Commission's enforcement power. ${ }^{78}$ Second, the ITSA requires penalties assessed to be paid into the United States Treasury; it does not authorize recovery of treble damages by a private litigant. ${ }^{79}$ Thus, even if a private plaintiff could claim treble damages under the ITSA, the plaintiff could not obtain the benefit of the sanction. The right to invoke the provisions of the Act is therefore meaningless for a private litigant unless he is thoroughly altruistic. Finally, the legislative history of the ITSA makes it clear that Congress intended the sanction to supplement the enforcement arsenal already available to the SEC. ${ }^{80}$ The record contains no indication that treble damages are available to the victim of insider trading.

\section{Scope of the ITSA.}

There are two problems with the ITSA's description of the proscribed activity to which the treble damages penalty applies. ${ }^{81}$ First, to the extent the Act describes the prohibited conduct at all, the description is not consistent with judicial enunciations of what constitutes illegal in-

77. Id.

78. See supra note 75 and accompanying text; 1983 House Hearings, supra note 14, at 230-31 (considering question of enforcement by private plaintiffs).

79. Section 2 of the ITSA amends the 1934 Act, $\S 21$ (d)(2)(A), 15 U.S.C. $\S 78 u(d)(2)(A)$ (Supp. II 1984), to provide: "The amount of such penalty . . . shall be payable into the Treasury of the United States." See also Thomas, supra note 34, at 445 (provision requiring penalty to be paid into the Treasury inserted to make the Act noncontroversial and assure speedy passage).

80. See 1984 Senate Hearings, supra note 14, at 11-12; 1983 House Hearings, supra note 14, at 56 (Chairman Shad indicating cumulative nature of ITSA by stating that Commission intended to use all remedies it already had in addition to treble damages sanction). But see Musslewhite, The Measure of the Disgorgement Remedy in SEC Enforcement Actions: SEC v. MacDonald, 12 SEC. REG. L.J. 138, 175 (1984) ("It is possible that because of the existence of the proposed statute [ITSA], a court will decide in a future SEC action for disgorgement that the disgorgement remedy is not necessary to enforce effectively the securities laws. This decision would result from a court's reexamination of whether disgorged profits should be made available to injured investors.").

For legislative history showing that the ITSA remedy was intended exclusively for use by the SEC, and not by private plaintiffs, see 1983 House Hearings, supra note 14, at 47 . In discussing whether a right to jury trial should be granted for cases brought under the ITSA, the SEC argued that such a right need not be granted because actions under the ITSA would be brought by the government, not by a private party. Id.; see also Atlas Roofing Co. v. Occupational Safety \& Health Review Comm'n, 430 U.S. $442,448-49$ n.6 (1977). For a discussion of the possibility of private actions under the ITSA, see 1983 House Hearings, supra note 14, at 230-31, 238, 257-59.

81. ITSA $\S 2,15$ U.S.C. $\S 78 u(d)(2)(A)$, (B) (Supp. II 1984). 
sider trading. This lack of consistency undoubtedly will create confusion and new issues for litigation.

The second problem with the ITSA's formulation of prohibited conduct is more fundamental. The statute fails to define the scope of the conduct subject to the penalty. The Act incorporates the substantive law of Rules $10 \mathrm{~b}-5$ and $14 \mathrm{e}-3$ for a definition of insider trading. The failure of the ITSA to define insider trading is not a serious problem as long as Rules $10 \mathrm{~b}-5$ and $14 \mathrm{e}-3$ make clear what activity is prohibited. ${ }^{82}$ The lines separating legal from illegal activity under Rules $10 \mathrm{~b}-5$ and $14 \mathrm{e}-3$, however, are not clear. The ITSA ignores the unsettled state of insider trading laws and the possibility that traders may act illegally without knowledge or reason to know that their conduct is illegal; the Act merely authorizes imposition of the treble damages penalty on all individuals who violate any of the relevant provisions.

1. Description of the Prohibited Conduct. The ITSA prohibits "purchasing or selling a security while in possession of material nonpublic information." 83 Interpreted literally, the Act extends to anyone who trades while in possession of material nonpublic information whether or not the information motivates the transaction. That is, mere possession of the information at the time of the trade creates a conclusive presumption that the information was a significant factor in the decision to buy or sell the security. While the breadth of this description furnishes the SEC with a powerful enforcement tool, it also requires the Commission to exercise its rulemaking authority carefully to ensure that the ITSA does not punish innocent trading.

The apparently broad embrace of the Act represents a change from existing judicial interpretations, which have construed Rule $10 \mathrm{~b}-5$ to prohibit trading on the basis of material nonpublic information. ${ }^{84}$ The courts

82. 1983 House Hearings, supra note 14 , at 41 (memorandum from SEC Office of General Counsel) ("In the majority of insider trading cases it is clear what the law proscribes."). Especially in cases in which an officer, director or other fiduciary trades on the basis of inside information, the standards of legality generally are well established. See the discussion in Chiarella v. United States, 445 U.S. 222, 229-30 (1980) and cases cited therein.

83. ITSA § 2, 15 U.S.C. § 78u(d)(2)(A) (Supp. II 1984) (emphasis added); see 1983 House Hearings, supra note 14 , at $48-50$.

84. Rule 14e-3, unlike section 10(b) and Rule 10b-5, does use this "in possession of" language. The discussion in the text accompanying notes 84-86 therefore does not encompass Rule 14e-3.

For examples of courts' use of the "on the basis of" language, see Dirks v. SEC, 463 U.S. 646, 653 n.10 (1983) (referring to "[t]he duty that insiders owe to the corporation's shareholders not to trade on inside information") (emphasis added); SEC v. Texas Gulf Sulphur Co., 401 F.2d 833, 839 (2d Cir. 1968) (complaint alleged that defendants purchased stock "on the basis of material inside information") (emphasis added), cert. denied, 404 U.S. 1005 (1971); SEC v. Musella, 578 F. Supp. 425, 438 (S.D.N.Y. 1984) (liability under Rule 10b-5 attaches to those "who trade on the basis of material nonpublic information tainted by the breach of an insider's fiduciary duty") (emphasis ad- 
have required that a causative relationship exist between the possession of information and the trade before finding a violation of Rule 10b-5. The "on the basis of" language used by the courts expresses this necessary causative link; the material nonpublic information must have been a substantial reason-a motivating factor-for the decision to trade in order for the trade to violate Rule $10 \mathrm{~b}-5$.

In many cases the difference in terminology-between "on the basis of" and "in possession of" - will not represent a difference in substance. Generally, if an individual is aware of certain information and such information is material, ${ }^{85}$ any trading done by the individual will be based at least in part on that information. It would be difficult, if not inpossible, to divorce an individual's awareness of an item of material nonpublic information about a security from the amassed knowledge that formed the basis of the individual's decision to trade in that security. Usually, therefore, one may establish the causal link between the information and the trading decision by showing that a defendant was aware of inaterial nonpublic information and traded in a manner consistent with the message conveyed by such information. Such a showing creates a presuinption that the trade was accomplished on the basis of, or because of, the new piece of nonpublic information, and the defendant generally is unable to rebut that presumption.

The difference between "trading while in possession of" information and "trading on the basis of" that information may be very significant, however, in the case of institutional investors and other non-natural per-

ded); cf. In re Cady, Roberts \& Co., 40 S.E.C. 907,911 (1961) ("We, and the courts have consistently held that insiders must disclose material facts which are known to them by virtue of their position but which are not known to persons with whom they deal . . . .") (emphasis added).

In Chiarella v. United States, 445 U.S. 222 (1980), the Court discussed In re Cady, Roberts \& Co., 40 S.E.C. 907 (1961), as a case in which the SEC held that "a broker-dealer and his firm violated that section $[10(\mathrm{~b})]$ by selling securities on the basis of undisclosed information." Chiarella, 445 U.S. at 226 (emphasis added); in his concurring opinion in Chiarella, Justice Brennan agreed with the majority that "a person violates $\S 10$ (b) whenever he improperly obtains or converts to his own benefit nonpublic information which he then uses in connection with the purchase or sale of securities." Id. at 239 (Brennan, J., concurring) (emphasis added); see also id. at 229 ("The federal courts have found violations of $\S 10(b)$ where corporate insiders used undisclosed information for their own benefit.") (emphasis added) (citation omitted).

85. A "fact is material if there is a substantial likelihood that a reasonable shareholder would consider it important in deciding" whether to buy, sell or hold onto his stock. TSC Indus., Inc. v. Northway, Inc., 426 U.S. 438, 449 (1976); cf. Dooley, supra note 20, at 6 (defining information as material "if the market price rose or fell upon its publication and if the previously trading insider thereby made a profit or avoided a loss").

Materiality is also relevant to causation in a Rule 10b-5 case. If an individual is aware of material nonpublic information about the securities in question and trades in a manner that is consistent with such information, because the information is material we can assume it motivated the individual's decision to trade. If the nonpublic information is not material, we cannot assume that it motivated a reasonable investor's, or this individual's, decision to trade. 
sons. ${ }^{86}$ An essential characteristic of an institutional investor or firm is that it has the capacity to act only through individuals. Accordingly, a firm may be in possession of information and act on a matter to which that information relates without the connection between the information and the action necessarily being brought hoine to any single individual within the firm.

Although the ITSA does not define the term "possession" for these purposes, the common law of agency may supply the necessary doctrine. Under the common law, a principal (here, the institution) legally "possesses" information whenever any of its agents or employees are cognizant of the information and the information is related to that agent's or employee's duties for the firm. ${ }^{87}$ Thus, a firm would be in possession of information if one of its researchers discovered the information in the course of his research activities.

Once the firm possesses the information, the ITSA indicates that any trade in the relevant securities executed on behalf of the firm is presumed to have been motivated by such information. It is easy to imagine a situation, however, in which the individual who executes a trade is unaware of the material nonpublic information discovered by the researcher. In this situation, the firm has traded while in possession of material nonpublic information, but there is no causal relationship between the possession of the information and the decision to trade. Under these circumstances, the firm should not be held to have violated the insider trading laws.

Congress anticipated this problem. The legislative history of the Act demonstrates Congress's expectation that the SEC would exercise its

86. See generally 1983 House Hearings, supra note 14 , at $48-49,177,196-97,208,244-46,297$, 315 (discussing "in possession of" language); Stevenson, supra note 66, at 18, 20 (suggesting that "in possession of' language will create issues for litigation due to its conflict with Chiarella and Dirks, both of which held that mere possession of information was not enough to obligate the trader to disclose or abstain).

87. See generally Restatement (SECOND) of AGENCY $\$ \S 272-282$ (1958). Generally, an agent's knowledge will be imputed to the principal whenever such knowledge concerns "a matter as to which . . . [the agent] acts within his power to bind the principal or upon which it is his duty to give the priucipal information." Id. $\S 272$.

Mechem suggests two reasons for this rule. First, "the agent, while keeping within the scope of his authority, is, as to the matters embraced within it, for the time being the principal himself, or, at all events, the alter ego of the principal-the principal's other self. Whatever notice or knowledge, then, reaches the agent under these circumstances, in law reaches the principal." F. MECHEM, A TREATISE ON THE LAW OF AGENCY $\S 719$, at 548 (1889). Second, "it is the duty of the agent to disclose to his principal, all notice or knowledge which he may possess and which is necessary for thc principal's protection or guidance. This duty the law presumes the agent to have performed . . . ." Id. 
rulemaking power to provide protection for firms in this situation. ${ }^{88}$ Congress had in mind a rule patterned after Rule 14e-3(b) that would provide that liability not be imposed on a firm if it showed, first, that the person who traded in the security on the firm's behalf did so without knowledge of the relevant material nonpublic information and, second, that the firm had enacted procedures to ensure that the material nonpublic information would not reach the person who traded on behalf of the firm. ${ }^{89}$ If the trader was unaware of the material nonpublic information and the firm had established procedures sufficient to keep separate its trading activities from its research activities, then the rule presumably will except the firm from liability under the ITSA because the trade would not have violated the insider trading prohibitions.

There are two significant consequences of the approach of the ITSA and the rule contemplated by Congress and the Commission. First, the rule would place the burden of proof on the defendant to show that the trade was not made on the basis of the material nonpublic information, rather than require the SEC to prove the causal nexus between the possession of information and the trade. ${ }^{90}$ That is, mere possession of material nonpublic information coupled with the occurrence of a trade consistent with such information would give rise to a presumption that the firm had violated the law. It would be up to the firm, then, to rebut the presumption. This seems to change the traditional allocation of the burdens of persuasion. It reduces the burden on the SEC and increases the burden on the defendant on the issue whether the person who traded for the firm knew of the material information at issue. ${ }^{91}$ Congress was

88. See HouSE REPORT, supra note 31, at 11; 1983 House Hearings, supra note 14, at 90 (statement of SEC General Counsel Goelzer); see also 130 CoNG. REC. S8913-14 (daily ed. June 29, 1984) (statement of Sen. D'Amato).

89. See Langevoort, supra note 31 , at 1283-84. Rule $14 \mathrm{e}-3$ (b) provides:

A person other than a natural person shall not violate paragraph (a) of this section if such person shows that:

(1)The individual(s) making the investment decision on behalf of such person to purchase or sell any security described in paragraph (a) of this section or to cause any such security to be purchased or sold by or on behalf of others did not know the material, nonpublic information; and

(2)Such person had implemented one or a combination of policies and procedures, reasonable under the circumstances, taking into consideration the nature of the person's business, to ensure that individual(s) making investment decision(s) would not violate paragraph (a) of this section, which policies and procedures may include, but are not limited to, (i) those which restrict any purchase, sale and causing any purchase and sale of any such security or (ii) those which prevent such individual(s) from knowing such information.

17 C.F.R. $\S 240.14 \mathrm{e}-3(\mathrm{~b})$ (1985).

90. See the lead-in to Rule 14e-3(b), supra note 89 , which states that a person will not be held to violate Rule 14e-3(a) if "such person shows that" the requirements of Rule 14e-3(b) are satisfied. 17 C.F.R. $\$ 240.14 \mathrm{e}-3$ (1985) (emphasis added).

91. Traditionally, of course, the plaintiff has the burden of proving each element of a prima facie case. One element in an action under section $10(\mathrm{~b})$ is that the defendant traded because of his knowledge of the material nonpublic information. In re Investors Management Co., 44 S.E.C. 633, 
either unaware of this change or simply failed to articulate its intent to modify the respective burdens of proof of the parties. In either case, this shift in the burden of proof is more efficient than the traditional approach, since the defendant institution usually has better access than the SEC to facts relevant to the trader's knowledge.

Second, the rule contemplated by Congress would condition nonliability on the existence of a Chinese Wall-a communication bar between researchers and traders-or other isolating procedures enacted by the firm. ${ }^{92}$ There may be cases, however, in which a firm has not established effective Chinese Wall or other isolating procedures and yet should not be held liable for a violation of the insider trading provisions. Such cases would arise whenever the person who traded on behalf of the firm can affirmatively prove that when he traded he was unaware of the material nonpublic information obtained by another member of the firm. The trader's affirmative proof of ignorance should rebut the presumption that the trade was motivated by the secret information, even though that ignorance did not result from the isolating procedures. The SEC should include an exception to liability to cover such a case in the rule it adopts pursuant to the Act.

641 (1971) (listing as one element of a case under Rule 10b-5 "that the information be a factor in his decision to effect the transactions") (footnote omitted); see also In re Cady, Roberts \& Co., 40 S.E.C. 907, 916 (1961) (finding that broker willfully violated sections 17(a) and 10(b) and Rule 10b-5; once he had heard the nonpublic information he "hastened to sell" his shares before the information was made public).

The language of the ITSA ought to reflect existing law if it is indeed not the purpose of the Act to alter such law. The use of the "in possession" language, when the legal standard requires a causal relationship between the information and the trade, will only create unnecessary confusion. Inevitably, a private plaintiff will use this language in the ITSA to argue that evidence of possession is sufficient to prove an unlawful use of information, even though circumstances may suggest that use was not prompted by possession.

During a discussion of the appropriate language for the 1TSA, Mr. Fedders, then Director of Enforcement at the SEC, stated that the "in possession of" standard had been used by courts in section 10(b) and Rule 10b-5 cases. 1983 House Hearings, supra note 14, at 49 . But sec cases cited supra note 84.

92. See SEC Securities Act Relcase Nos. 6239, 17,120, 11,336, [1980 Transfer Binder] FED. SEC. L. REP. (CCH) If 82,646 (Sept. 4, 1980) (discussing use of Chinese Wall or other isolating procedure in context of Rule 14e-3); see also Slade v. Shearson, Hammill \& Co., 517 F.2d 398, 403 (2d Cir. 1974) (noting that SEC favors use of Chinese Walls); In re Merrill Lynch, Pierce, Fenner \& Smith, Inc., Securities Exchange Act Release No. 8459, [1967-1969 Transfer Binder] FED. SEC. L. REP. (CCH) I 77,629 (Nov. 25, 1968) (as part of settlement with SEC for a violation of Rule 10b-5, Merrill Lynch adopted a statement of policy to effectuate a Chinese Wall); Herzel \& Colling, The Chinese Wall Revisited, 6 CoRP. L. REv. 116 (1983); Herzel \& Colling, The Chinese Wall and Conflict of Interest in Banks, 34 Bus. LAw. 73 (1978); Huck, The Fatal Lure of the "Impermeable Chinese Wall," 94 Banking L.J. 100 (1977); Lipton \& Mazur, The Chinese Wall Solution to the Confict Problems of Securities Firms, 50 N.Y.U. L. REv. 459 (1975); Varn, The Multi-Service Securities Firm and the Chinese Wall: $A$ New Look in the Light of the Federal Secinities Code, 63 NEB. L. REV. 197 (1984). 
In addition to uncertainty whether a causative link must exist between the information and the trade, another ambiguous aspect of the ITSA - a firm's liability for nonmanagement employees' trading - should be cured by the Commission's exercise of its rulemaking authority. The Act leaves unclear whether any employee, even a very junior employee, can expose the employer-firm to liability for treble damages by trading on the firm's behalf on the basis of material nonpublic information in violation of Rule 10b-5 or Rule 14e-3. All that is clear from the legislative history of the Act is that if the board of directors or senior management of the firm knows of the material nonpublic information and directs the trade, the firm is subject to the treble damages penalty..$^{93}$ Neither the legislative history of the Act nor the administrative record of Rule 14e-3, after which Congress anticipated the new rule would be patterned, addresses firm liability for trading by lower-level employees. ${ }^{94}$ Without an exception, then, it seems that the treble damages penalty could be sought in a case where any employee of the firm traded on the basis of material nonpublic information for the firm.

Liability of a firm for trading by employees below the senior level is inconsistent with the Act's exphicit rejection of liability for the treble damages penalty based on the doctrine of respondeat superior. ${ }^{95}$ If the doctrine applied, the firm could be held liable when an employee generally authorized to trade on the firm's behalf did so on the basis of material nonpublic information. ${ }^{96}$ Because Congress rejected the respondeat superior doctrime in the ITSA, the SEC ought to provide an exclusion from the penalty for firm trading done by low-level employees. The Commission should also specifically define those senior-level employees whose trading will result in a penalty against the firm.

2. Absence of a Definition of Insider Trading. The failure of the ITSA to define insider trading is troublesome. The outer boundaries of liability for insider trading under Rule 10b-5 have been in an almost constant state of flux since In re Cady, Roberts \& Co., the seminal decision that first articulated the duty to refrain from trading on material nonpub-

93. See HouSE REPORT, supra note 31, at 10 ("Thus, if the board of directors of a corporation, while having material nonpublic information, directed an employee to trade for the corporation's account, the corporation itself would be liable for the penalty."); see also 1984 Senate Hearings, supra note 14 , at $26-27$.

94. See Securities Exchange Act Release No. 17,120, [1980 Transfer Binder] FED. SEC. L. REP. (CCH) If 82,646, at 83,463-64 (Sept. 4, 1980).

95. But see Langevoort, supra note 31 , at 1283-84 (asserting that nonmanagerial employee's trading could subject employer to liability under ITSA).

96. See Sharp v. Coopers \& Lybrand, 649 F.2d 175, 180-83 (3d Cir. 1981), cert. denied, 455 U.S. 938 (1982). 
lic information. ${ }^{97}$ The most recent adjustments by the Supreme Court to the scope of duty created by Rule 10b-5 occurred in Chiarella and Dirks. ${ }^{98}$ Most of the uncertainty today centers on the potential liability of persons who do not fit within the traditional categories of "insiders," which include officers, directors, controlling shareholders and other fiduciaries. New theories of liability-the misappropriation theory in particular-have been developed to find "outsiders" liable for trading on the basis of material nonpublic information. The Supreme Court has not yet determined the validity of the misappropriation theory. Nor has it addressed two other issues arising under Rule 10b-5: whether only intentional conduct violates the provision or merely reckless acts suffice; and whether these provisions prohibit "front-running." dimensions of the prohibition against insider trading are unclear. Defendants whose conduct does not clearly violate the underlying provisions of the ITSA-Rule 10b-5 and Rule 14e-3-may use this lack of clarity to argue that they did not have adequate notice that their conduct was illegal and that the imposition of a penalty is therefore unfair.

97. In In re Cady, Roberts \& Co., 40 S.E.C. 907,912 (1961), the SEC announced that a duty to disclose material nonpublic information or refrain from trading until such disclosure is made rests on two factors:

first, the existence of a relationship giving access, directly or indirectly, to information intended to be available only for a corporate purpose and not for the personal benefit of anyone, and second, the inherent unfairness involved where a party takes advantage of such information knowing it is unavailable to those with whom he is dealing.

Id. (footnote omitted). Later, in SEC v. Texas Gulf Sulphur Co., 401 F.2d 833 (2d Cir. 1968), cert. denied, 404 U.S. 1005 (1971), Judge Waterman found that Rule 10b-5 is "based in policy on the justifiable expectation of the securities marketplace that all investors trading on impersonal exchanges have relatively equal access to material information." Id. at 848 (citations omitted). This "parity of information" rule was rejected by the Supreme Court in Chiarella, 445 U.S. at 232-33; see supra notes 47-65 and accompanying text (discussing Chiarella and Dirks); see also Schein v. Chasen, 478 F.2d 817, 828 (2d Cir. 1973) (Kaufman, J., dissenting) ("exact nature and scope" of the federal law governing tippee trading liability "remain in a formative stage"), vacated on other grounds sub nom. Lehman Brothers v. Schein, 416 U.S. 386 (1974).

98. See Dirks, 463 U.S. at 658-61 (trading on material nonpublic information violates Rule 10b. 5 only if trader or tipper had fiduciary relationship with other investors and benefitted personally by the tip); Chiarella, 445 U.S. at 232-35 (in the absence of a fiduciary-type relationship between the inside trader and other investors in the securities, no duty to disclose material nonpublic information arises); Zweig v. Hearst Corp., 594 F.2d 1261, 1269 (9th Cir. 1979) (defendant must have a fiduciary relationship with the plaintiff to be within the scope of Rule 10b-5); SEC v. Texas Gulf Sulphur Co., 401 F.2d 883, 848 (2d Cir. 1968) ("[A]nyone in possession of material inside information must either disclose it to the investing public, or . . . must abstain from trading in or recommending the securities concerned while such inside information remains undisclosed.") (emphasis added), cert. denied, 404 U.S. 1005 (1971); In re Cady, Roberts \& Co., 40 S.E.C. 907,912 (1961) (duty to disclose or abstain from trading arises from "the existence of a relationship giving access, directly or indirectly, to information intended to be available only for a corporate purpose and not for the personal benefit of anyone, and, second, the inherent unfaimess involved where a party takes advantage of such information knowing it is unavailable to those with whom he is dealing") (footnote omitted).

99. Front-running occurs when a person trades on information about other trading in the same securities. See infra notes $134-38$ and accompanying text. 
One example of the current confusion surrounding the scope of Rule $10 \mathrm{~b}-5$ 's application to outsiders revolves around the use of the misappropriation theory. This theory, based upon the concurring opinion of Justice Stevens in Chiarella, ${ }^{100}$ posits that an employee who takes confidential, material nonpublic information from the employer and trades on the basis of it violates a duty under Rule 10b-5.101 The duty arises from the employment relationship; it obligates an employee to refrain from using confidential information gained from the employment for personal benefit. The misappropriation theory is used most often in cases in which a defendant trades in the securities of a company that is the target of a proposed, but as yet unannounced, tender offer. Although the defendant has no relationship to the target company, he learns of the intended tender offer through someone connected with the proposed transaction. As in Chiarella, the defendant in such circumstances has no fiduciary or other relationship to the target or its stockholders. ${ }^{102}$ Under the analysis of Rule 10b-5 articulated in Chiarella, no liability would attach. Thus, the misappropriation theory provides a way to hold a defendant like Chiarella liable under Rule 10b-5 even though the defendant breached no duty owed to the holders of the traded securities.

The Supreme Court has not upheld the misappropriation theory, and there are several reasons to question the theory's viability. ${ }^{103}$ The theory depends on the existence of a duty owed by an employee to his employer to refrain from using employment-related information for personal benefit. ${ }^{104}$ Proponents of the misappropriation theory derive this duty from the common law obligations resulting from the employee's

100. Chiarella, 445 U.S. at 237 (Stevens, J., concurring).

101. Justice Stevens posed the question of liability under the misappropriation theory as "whether the petitioner's breach of his duty of silence-a duty he unquestionably owed to his employer and his employer's customers-could give rise to criminal liability under Rule 10b-5." Id. at 238. See generally Aldave, Misappropriation: A General Theory of Liability for Trading on Nonpublic Information, 13 HofsTrA L. REv. 101 (1984).

A variant on the misappropriation theory was suggested by Chief Justice Burger in his dissent in Chiarella. He argued that section 10(b) imposes on "a person who has misappropriated nonpublic information ... an absolute duty to disclose that information or to refrain from trading." Chiarella, 445 U.S. at 240 (Burger, C.J., dissenting). This obligation does not require that the misappropriation constitute a breach of duty to someone, as does Justice Stevens's version of the theory.

102. See Chiarella, 445 U.S. at 232-33.

103. The Supreme Court recently denied certiorari in SEC v. Materia, 745 F.2d 197 (2d Cir. 1984), cert. denied, 105 S. Ct. 2112 (1985), a case in which liability rested on the misappropriation theory. Only the Second Circuit has upheld the misappropriation theory as of the date of this article. But in Bateman Eichler, Hill Richards, Inc. v. Berner, 105 S. Ct. 2622 (1985), the Supreme Court indicated in dicta its support of the misappropriation theory: "We have also noted that a tippee may be liable if he otherwise "misappropriate[s] or illegally obtain[s] the information." "Id. at 2630 n.22 (Brennan, J.) (quoting Dirks, 463 U.S. at 655).

I04. See Chiarella, 445 U.S. at 238 (Stevens, J., concurring). 
agency relationship with the principal. ${ }^{105}$ An agent has a duty to refrain from profiting personally by using any confidential information acquired during the course of the agent's employment. ${ }^{106}$ This common law duty is not limited to use of the information that causes an injury to the principal. Rather, in order to "avoid difficult factual inquir[ies] and prevent the conflict of interest," it reaches all uses of confidential information by an agent for personal gain. ${ }^{107}$ In short, simply by using confidential information to trade in securities, the agent breaches this obligation to the principal. ${ }^{108}$

Basing a violation of Rule 10b-5 on the defendant-employee's breach of this duty to the employer, however, is inconsistent with judicial constructions of the provision, which predicate liability on injury to persons to whom a duty is owed. ${ }^{109}$ Since the employer is not an investor in the securities traded by the defendant, the employer is not directly injured by the employee-trader's breach of duty. The requirement of a predicate injury underlies the need for plaintiffs in private actions under Rule 10b5 to establish standing to sue by proving that they were purchasers or sellers of the securities in which the defendant traded. ${ }^{10}$ While the purchaser-seller rule has not been applied in enforcement actions brought

105. See Restatement (Second) of Agency $\S 388$ (1958). But the language of section 388 itself does not support the notion of a duty of the employee in these circumstances. It prohibits profit by an agent from "transactions conducted by him on behalf of the principal." Id. Here, the agent profits by trading, not on behalf of the principal, but solely for himself.

106. See Barry, The Economics of Outside Information and Rule 10b-5, 129 U. PA. L. REV. 1307, 1360-74 (1981) (arguing that common law prohibits agent from using information gained from principal for any purpose not intended by principal); see also Block \& Hoff, Life After Dirks: Can Outsider Trading Constitute Fraud?, Nat'1 L.J., Sept. 19, 1983 at 15, 19-20 (questioning whether investment banking firm of acquiring corporation in tender offer owes any duty to target company to refrain from trading on basis of undisclosed information about anticipated tender offer).

While directors do not fit neatly into the category of agents because the corporation-principal cannot act without them, and thus cannot practically direct them, they nonetheless are considered agents for purposes of the fiduciary duties they owe to the corporation and its shareholders. RESTATEMENT (SECOND) OF AGENCY $\$ 388$ comment c (1957).

107. Langevoort, Insider Trading and the Fiduciary Principle: A Post-Chiarella Restatement, 70 CAlif. L. Rev. 1, 19 n.74 (1982); see Restatement (SeCOND) OF AGeNCY $\$ 388$ comment c (1957). The Restatement provides, however, that the principal and agent may alter this rule by agreement. Id.

108. In some cases, as in Chiarella, the tender offeror, who is in the investing market, would be affected. See SEC v. Wyman, Litigation Release No. 9311,22 S.E.C. Docket 391 (S.D.N.Y. Feb. 23, 1981) (consent decree); Langevoort, supra note 107, at 48-49.

109. Chiarella, 445 U.S. at 233; see also Prosser, HANDBOoK OF THE LAW OF TORTS 731 (4th ed. 1971) (injury is element of prima facie case of fraud under common law).

110. Birnbaum v. Newport Steel Corp., 193 F.2d 461, 464 (2d Cir.) (Rule 10b-5 extends protection only to defrauded seller or purchaser), cert. denied, 343 U.S. 956 (1952); see also Blue Chip Stamps v. Manor Drug Stores, 421 U.S. 723, 749-55 (1975) (adopting Birnbaum rule). 
under Rule $10 \mathrm{~b}-5,111$ a lack of investment interest by the principal does bear on the soundness of the misappropriation theory. Rule $10 \mathrm{~b}-5$ prohibits fraud "in connection with the purchase or sale of any security." "112 One must ask, therefore, whether anyone was defrauded and whether the fraud was sufficiently associated with the trading in securities to come within the scope of Rule 10b-5.113

The Supreme Court has interpreted the term "fraud" in Rule 10b-5 to require proof of deception. ${ }^{114}$ " $[\mathrm{R}] \mathrm{ule} 10 \mathrm{~b}-5$ cases have consistently involved a deception connected to the deceived person's purchase or sale of a security, a decision not to purchase or sell, or some other investinent related activity."11s This connection between the deception and an investor does not appear in cases in which the SEC invokes the inisappropriation theory. ${ }^{116}$ Not all breaches of fiduciary duty include deception. ${ }^{117}$ For example, an open and notorious use of confidential information by an employee for purposes of trading in securities may be a breach of fiduciary duty, but it does not deceive the principal. Thus, the necessity of finding deception appears to preclude using the misappropriation theory in many of the situations to which it was designed to apply.

Even assuining that inisappropriation does deceive the principal, if the principal has made no investment decision related to the securities traded by the agent, one must question whether the employee's trading violates section $10(\mathrm{~b})$. The statute is designed primarily to protect investors, ${ }^{118}$ and the "injured" party, the employer, is not among thein. Moreover, an action for fraud at common law required a showing of injury by the party defrauded." 19 "[A] statutory provision that prohibits fraud and deception in connection with a purchase or sale of securities

111. See, e.g., United States v. Newman, 664 F.2d 12, 17 (2d Cir. 1981), cert. denied, 464 U.S. 863 (1983).

112. 17 C.F.R. $§ 240.10 \mathrm{~b}-5$ (1985) (emphasis added).

113. Superintendent of Ins. v. Bankers Life \& Casualty Co., 404 U.S. 6, 12-13 (1971) ("The crux of the present case is that [the plaintiff] suffered an injury as a result of deceptive practices touching its sale of securities as an investor.") (emphasis added).

114. In Santa Fe Indus. v. Green, 430 U.S. 462, 473-74 (1977), the Supreme Court held that deception is a necessary element of a claim under section 10(b) and Rule 10b-5. In that case, a breach of fiduciary duty was alleged, and there was full disclosure made of such breach, id. at 467; the Supreme Court ruled that no cause of action under Rule 10b-5 had been stated. Id. at 474 .

115. Langevoort, supra note 107 , at 46.

116. See id. at 46-47. If the agent had permission to use the information for his personal benefit, such use, of course, would not amount to deception.

117. See supra note 114; see also Brudney, Insiders, Outsiders, and Informational Advantages under the Federal Securities Laws, 93 HARV. L. REv. 322, 350-53 (1979) (distinguishing breaches of fiduciary duty from narrower category of breaches of fiduciary duty involving deception).

118. See, e.g., Ernst \& Ernst v. Hochfelder, 425 U.S. 185, 195 (1976); United States v. Newman, 664 F.2d 12, 20 (2d Cir. 1981) (Dumbald, J., concurring and dissenting), cert. denied, 464 U.S. 863 (1983); Aldave, supra note 101, at 117-21.

119. See supra note 109. 
should require a showing that the person allegedly defrauded was engaged in some investment related activity in order to establish liability." 120 Here, the employer was not involved in any investment decision, yet it is the breach of duty of the defendant to the employer that results in liability. It is difficult to see how such a set of facts satisfies the "in connection with" language of section 10(b), or the notion that fraud requires some showing of injury.

On the other hand, in addition to protecting investors, section 10(b) was intended to protect the integrity of the securities market. ${ }^{121}$ It has been argued that since insider trading undermines the public's confidence in the market, all trading on nonpublic information should be within the scope of a section 10(b) enforcement action. ${ }^{122}$ Under this argument, a defendant's own trading in securities satisfies the necessary link to the purpose of section 10(b) as well as the causation requirement embodied in the "in connection with" language.

This reliance on the defendant's own trading seems to prove too much. If the basis for labelling the trading "bad"- that is, a violation of a fiduciary duty owed by the defendant-has no relationship to any investment activity by the defrauded principal, it is difficult to see how this trading constitutes a fraud that touches another's investment decision. Whatever fraud exists is on one person, while the investment is by others. This disassociation of the fraud from the investors conflicts with the Supreme Court's decision in Chiarella. There the Supreme Court went to great lengths to state that only trading that breaches $a$ duty to someone who is also trading violates section $10(\mathrm{~b}) .^{123}$ The improper use of the information forms the basis of the misappropriation theory, rather than any relationship between that use in trading and another investor as to whom such use of information was improper. The lack of a breach of duty to or deception of anyone who traded in the securities renders the misappropriation theory of doubtful validity. ${ }^{124}$

The SEC has used the misappropriation theory in several of its en-

120. Langevoort, supra note 31, at 1297 (footnote omitted).

121. See United States v. Naftalin, 441 U.S. 768, 775 (1979); United States v. Newman, 664 F.2d 12, 18-19 (2d Cir. 1981), cert. denied, 464 U.S. 863 (1983).

122. See, e.g., HOUSE REPORT, supra note 31 , at $4-5$.

123. See Chiarella v. United States, 445 U.S. 222, 230 (1980) ("Such liability [under Rule 10b-5] is premised upon a duty to disclose arising from a relationship of trust and confidence between parties to a transaction.") (emphasis added); Dirks v. SEC, 463 U.S. 646, 654-55 (1983).

124. In the hearings on the ITSA, the SEC and some members of Congress clearly endorsed the misappropriation theory. See 1984 Senate Hearings, supra note 14, at 34; 1983 House Hearings, supra note 14, at 17 (statement of Chairman Shad); id. at 36 (statement of Rep. Wirth); see also Anderson, Fraud, Fiduciaries, and Insider Trading, 10 HoFstRa L. Rev. 341, 345 n.21 (1982) (discussing deficiencies in Second Circuit's opinion in Newman, and lack of consistency between misappropriation theory and Chiarella). See generally Note, An Outsider Who Misappropriates 
forcement actions ${ }^{125}$ and no doubt will continue to do so, at least until the theory is judged by the Supreme Court. With the advent of the ITSA, the validity of the theory assumes greater significance, since the SEC is likely to invoke it not only in seeking disgorgement but also in seeking treble damages. When a penalty is imposed, purposes of specific deterrence and requirements of fairness are only served when the defendant is able to recognize from previous articulations of the standards of legality that his conduct violates the law. ${ }^{126}$

In addition to the misappropriation theory, another ambiguous aspect of the law prohibiting insider trading is the degree of scienter that a defendant must have before liability can be imposed under section 10(b) and Rule 10b-5. The Supreme Court has held that scienter, that is, intentional conduct, ${ }^{127}$ violates Rule $10 \mathrm{~b}-5$, but has left open the question whether recklessness can support liability. All lower federal courts that have considered the issue, however, have decided that some form of recklessness is sufficient. ${ }^{128}$

Confidential Information May Be Charged With Securities Fraud: United States v. Newman, 31 DePaul. L. Rev. 849 (1982).

In SEC v. Gaspar, [1984-1985 Transfer Binder] FED. SEC. L. REP. (CCH) ๆ 92,004 (S.D.N.Y. Apr. 15, 1985), the misappropriation theory was used to find a tipper and tippee liable under Rules $10 \mathrm{~b}-5$ and $14 \mathrm{e}-3$. The court held that even though the tipper had no fiduciary relationship to the corporation in whose securities the tippee traded and to which the tip related, the tip constituted a breach of duty of the tipper to his employer, and this was sufficient to find liability under $10 \mathrm{~b}-5$. $I d$. at 90,978-79. This seems to be in clear conflict with Dirks.

125. See, e.g., SEC v. Materia, 745 F.2d 197, 201 (2d Cir. 1984), cert. denied, 105 S. Ct. 2112 (1985); SEC v. Gaspar, [1984-1985 Transfer Binder] FED. SEC. L. REP. (CCH) I 92,004 (S.D.N.Y. Apr. 15, 1985); SEC v. Musella, 578 F. Supp. 425, 438 (S.D.N.Y. 1984); SEC v. Brant, [1984 Transfer Binder] FED. SEC. L. REP. (CCH) \91,571 (S.D.N.Y. July 12, 1984).

126. See Hart, The Aims of the Criminal Law, 23 LAw \& Contemp. ProBs. 401, 422 (1958). But see Kadish, Some Observations on the Use of Criminal Sanctions in Enforcing Economic Regulations, 30 U. CH1. L. REV. 423, 441-42 (1963).

127. Ernst \& Ernst v. Hochfelder, 425 U.S. 185, 197 (1976). Scienter "refers to a mental state embracing intent to deceive, manipulate or defraud." Id. at 194 n.12. An insider who actually knows that he has material nonpublic information at the time he trades will be found to have the requisite mental state for liability under section 10(b). SEC v. MacDonald, 699 F.2d 47, 50 (1st Cir. 1983). The Second Circuit expanded that definition in the context of tipping in Elkind v. Liggett \& Myers, 635 F.2d 156 (2d Cir. 1980). For that purpose, an insider who deliberately tips information which he knows is material and nonpublic to an outsider who may use that information to his benefit will satisfy the requirement of scienter. Id. at 167; see also ABA Task Force Report, supra note 63, at 241 (requiring knowledge of or recklessness as to facts which give rise to the duty to disclose or abstain from trading).

128. See, e.g., White v. Sanders, 689 F.2d 1366, 1368-69 (11th Cir. 1982) (judgment n.o.v. improper where there was conflicting evidence about whether insurance agent was "severely reckless" in interpreting the safety of notes); Dirks v. SEC, 681 F.2d 824, 844 (D.C. Cir. 1982) (recklessness sufficient to warrant aider and abettor liability under Rule 10b-5), rev'd on other grounds, 463 U.S. 646 (1983); Hackbart v. Holmes, 675 F.2d 1114, 1117-18 (10th Cir. 1982) (reckless incorporator liable to investor for failing to ensure investor's knowledge of the terms of investment); Sharp $\mathbf{v}$. Coopers \& Lybrand, 649 F.2d 175, 193-94 (3d Cir. 1981) (accounting firm liable under 10b-5 for its employee's reckless issuance of tax opinion letter), cert. denied, 455 U.S. 938 (1982); Broad v. 
Under Rule 14e-3, a violation of which also may give rise to treble damages under the Act, the issue of scienter is clearer. Rule 14e-3 specifies that the defendant must know or have reason to know the source of the material nonpublic information, and must know or have reason to know that the information is nonpublic. ${ }^{129}$ Although the Rule does not define "reason to know," this standard is well developed in the law generally. Moreover, the SEC suggested in its release announcing the adoption of the Rule that the "reason to know" standard implies a duty of inquiry by a person in possession of facts sufficient to raise the suspicion of a reasonable person. ${ }^{130}$

These requirements of scienter under Rules $10 \mathrm{~b}-5$ and $14 \mathrm{e}-3$ do not guarantee that a defendant held liable knew that his conduct violated the law. ${ }^{131}$ On the contrary, the defendant's knowledge of the law is irrelevant for purposes of civil enforcement of the insider trading laws. ${ }^{132}$ Since the law is ambiguous in some respects, however, the traditional scienter requirement-which may be appropriate in traditional civil enforcement actions - may be inadequate to ensure that the defendant de-

Rockwell Int'l Corp., 642 F.2d 929, 961 (5th Cir.) (failure to disclose convertability of debenturcs into options, prior to merger, was not actionable under $10 \mathrm{~b}-5$ in the absence of "severe recklessness"), cert. denied, 454 U.S. 965 (1981); Keirnan v. Homeland, Inc., 611 F.2d 785, 788 (9th Cir. 1980) (real estate investment company liable under $10 \mathrm{~b}-5$ for reckless misstatements in partnership prospectus); Hoffman v. Estabrook \& Co., 587 F.2d 509, 516-17 (1st Cir. 1978) (although recklessness will support a $10 \mathrm{~b}-5$ action, underwriter's false statements in private placement solicitation were not reckless); Berhadl v. SEC, 572 F.2d 643, 647 n.6 (8th Cir. 1978) (indicating, without ruling definitively, that "gross recklessness" will satisfy scienter requirement); Rolf v. Blyth, Eastman Dillon \& Co., 570 F.2d 38, 47-48 (2d Cir.) (broker aided and abetted investment advisor's 10b-5 violation by virtue of reckless assurances of confidence to investor where fiduciary duty existed), cert. denied, 439 U.S. 1039 (1978); Sanders v. John Nuveen \& Co., 554 F.2d 790, 795-97 (7th Cir. 1977) (underwriter not liable for misstatements to commercial paper purchasers where underwriter not reckless).

129. See Securities Exchange Act Rel. Nos. 6239, 17,120, [1980 Transfer Binder] FED. SEc. L. REP. (CCH) \ 82,646, at 83,458 (Sept. 4, 1980). Paragraph (a) of Rule 14e-3 provides:

If any person has taken a substantial step or steps to commence, or has commenced, a tender offer (the "offering person"), it shall constitute a fraudulent, deceptive or manipulative act or practice within the meaning of section 14(e) of the Act for any other person who is in possession of material information relating to such tender offer which information he knows or has reason to know is nonpublic and which he knows or has reason to know has been acquired directly or indirectly from: (1) the offering person, (2) the issuer of the securities sought or to be sought by such tender offer, or (3) any officer, director, partner or employee or any other person acting on behalf of the offering person or such issuer, to purchase or sell or cause to be purchased or sold any of such securities or any securities convertible into or exchangeable for any such securities or any option or right to obtain or to dispose of any of the foregoing securities, unless within a reasonable time prior to any purchase or sale such information and its source are publicly disclosed by press release or otherwise.

17 C.F.R. $\S 240.14 \mathrm{e}-3$ (1985) (emphasis added).

130. Securities Exchange Act Rel. No. 17,120, [1980 Transfer Binder] FEd. SEc. L. REP. (CCH)

$\uparrow 82,646$, at 83,458 n.36.

131. See supra note 129.

132. See supra note 127. 
serves punishment of the sort provided in the ITSA as opposed to the traditional remedies available in a civil action. ${ }^{133}$

A third unsettled area of the law regulating insider trading concerns a practice commonly known as "front-runnimg." Front-running occurs when a person trades on information about other trading in the same securities. ${ }^{134}$ For example, if a broker-dealer learns that a customer has placed an order to sell a large block of stock, ${ }^{135}$ the broker-dealer could profit before the sale is disclosed to the market by selhing his stock in the same company before the market price declines as a result of the block trade. ${ }^{136}$ The congressional hearings on the ITSA demonstrate the desire of the Commission and some members of Congress that Rule 10b-5 prohibit front-running. ${ }^{137}$ So far, Rule $10 \mathrm{~b}-5$ has not been applied to frontrunning, although the exchanges and the NASD have the authority to regulate it. 138

It is doubtful whether Rule $10 \mathrm{~b}-5$ as construed by Dirks and Chiarella reaches front-running, since the broker-dealer owes no duty to the corporation in whose securities he trades. ${ }^{139}$ One could only obviate the requirement that a duty exist between the broker-dealer and other traders in the security by resort to the misappropriation theory. Under that theory, the broker-dealer's use of the information about the block trade might constitute a breach of duty either to his employer, if the broker-dealer traded on his own behalf, or to his employer's customer,

133. See infra notes $278-86$ and accompanying text.

134. See, e.g., S.E.C. Release No. 20,663 (Feb. 17, 1984) (defining front-ruining), reprinted in 29 S.E.C. Docket 1400, 1403 n.32 (1984); S.E.C. Release No. 14,156 (Nov. 9, 1977) (same), reprinted in 13 S.E.C. Docket 661,661 (1977).

135. A block trade is a purchase or sale of a large quantity of shares (usually 10,000 or more shares) in one consolidated transaction.

136. In order to accommodate investors' desires to make block trades, a number of registered broker-dealers maintain block trading departments. Typically, block trades are privately negotiated transactions and are not auctioned on the exchange floor. Results of a privately negotiated block trade are made public after the consummation of the transaction. The terms of the trade-number of securities traded and price per share-are brought to the exchange floor to appear on the tape and to comply with Exchange Rule 394, which prohibits exchange members from engaging in off-board trading in shares listed on the New York Stock Exchange. See generally J. CoHEN, E. ZiNBARG \& A. Zeikel, InVestment ANAlysis AND Portfolio MANAGEMENT 88-95 (4th ed. 1982).

137. See 1983 House Hearings, supra note 14, at 36.

138. See NASD By-Laws, Article XII, Rules of Fair Practice, NASD Manual (CCH) \ 1251 (1985) (conferring on exchange general rulemaking authority); S.E.C. Release No. 20,663, supra note 134, at 1403 \& n.32 (discussing New York Stock Exchange's rules against front-running); S.E.C. Release No. 14,156, supra note 134, at 661-62 (discussing Chicago Board Options Exchange's proposed rule against front-running); see also Paine Webber Fined By Big Board, CBOE For "Front Running, "Wall St. J., June 12, 1985, $\S 1$, at 12, col. 2 (report of censure and fine of Paine Webber, Inc. by New York Stock Exchange and Chicago Board Options Exchange for different kind of activity, also labelled front-running; Paine Webber allegedly bought shares and options for shares in company it was about to recommend to its clients for investment).

139. See supra notes 101-17 and accompanying text. 
the block trader, if the broker-dealer traded on his firm's account. ${ }^{140}$ Thus, the soundness of the misappropriation theory becomes more significant.

In short, the ITSA makes determining the soundness of the misappropriation theory important for two reasons. First, the SEC may employ the theory to assess treble damages for conduct not clearly violative of section 10(b) and Rule 10b-5 as interpreted in Chiarella and Dirks and for which only disgorgement could have been sought prior to the ITSA. Second, the theory appears to provide the only means for effecting Congress's intent that front-running be punishable under these provisions. More generally, the ITSA raises questions of fairness to the extent it permits severe penalties for conduct not clearly proscribed.

In light of these and other areas of ambiguity in the law under section 10(b) and Rule 10b-5, Congress and the SEC did consider including a definition of insider trading in the Act. ${ }^{141}$ Several definitions were proposed. First, the proposed Federal Securities Code of the American Law Institute contains a provision that prohibits traditional insider trading. ${ }^{142}$

\footnotetext{
140. See supra notes 101-17 and accompanying text.

141. See 1984 Senate Hearings, supra note 14, at 34-39; 1983 House Hearings, supra note 14, at
} 50-55.

In addition to the proposed definitions discussed in the text accompanying notes $142-48 \mathrm{infra}$, a definition was suggested by the New York State Bar Association that would have specified that the trader must have known that the "information was obtained directly or indirectly from the issuer, an affiliate of the issuer or a person or affiliate of a person who has commenced or has taken substantial steps to commence a tender offer." 1983 House Hearings, supra note 14, at 308. Moreover, the New York State Bar's draft would require the SEC to prove a violation by clear and convincing evidence in order to recover the penalty. Id. See infra notes 190-224 and accompanying text. In addition to the $A B A$ Task Force Report proposal that is discussed infra text at notes $144-45$ and reproduced infra note 145, the Task Force proposed an alternative definition of insider trading that generally prohibits trading and tipping on the basis of material nonpublic information; it requires proof by a preponderance of evidence that the trader or tipper knew, or was reekless in not knowing, that the information was material and nonpublic and that the information was obtained through a breach of a contractual, fiduciary, or other legal duty. ABA Task Force Report, supra note 63, app. B, at 264.

Several commentators opposed the inclusion of a definition of insider trading in the ITSA. Sec, e.g., 1983 House Hearings, supra note 14, at 238-42 (statement of Ted J. Fiflis, Professor of Law, University of Colorado Law School); id. at 197, $278-82$ (statement of Arnold S. Jacobs); id. at 234-35 (statement of A.A. Sommer, Jr.).

142. Section 1603 of the American Law Institute's proposal, 2 FEDERAL SECurities CODE $\S 1603$ (1978) [hereinafter cited as ALI PROPOSAL] provides:

SEC. 1603. (a) GENERAL.-It is unlawful for an insider to sell or buy a security of the issuer, if he knows a material fact with respect to the issuer or the security that is not generally available, unless-

(1) the insider reasonably believes that the fact is generally available;

(2) the identity of the other party to the transaction (or his agent) is known to the insider and (A) the insider reasonably believes that that party (or his agent) knows the fact, or (B) that party (or his agent) knows the fact from the insider or otherwise; or

(3) the insider proves that the fact is not a fact of special significance, except that this defense is not available in an action or proceeding by the Commission under section 1809, $1810,1811,1812,1815$, or 1819 (a). 
The section defines the category of persons who may be considered insiders. In doing so, it clarifies one serious ambiguity in the present law. That section, however, covers trading only by traditional insiders; other fraudulent trading practices, which would include trading now covered by the misappropriation theory, are dealt with in a broad antifraud provision much like Rule 10b-5. ${ }^{143}$

Second, a task force of members of the Federal Regulation of Securities Committee of the Section of Corporation, Banking and Business Law of the American Bar Association drafted a proposed statute that was directed at traditional insider trading as well as at other undesirable trading practices. The proposal proscribed trading by clearly defined classes of insiders and fiduciaries. It also prohibited trading on the basis of misappropriated information, relying on the version of the misappropriation theory articulated by Chief Justice Burger in Chiarella, ${ }^{144}$ which prohibited the use of any information illegally acquired. ${ }^{145}$ The proposal did

(b) INSIDER.-For purposes of section 1603, "insider" means (1) the issuer, (2) a director or officer of, or a person controlling, controlled by, or under common control with, the issuer, (3) a person who, by virtue of his relationship or former relationship to the issuer, knows a material fact about the issuer or the security in question that is not generally available, or (4) a person who learns such a fact from a person within section 1603(b) (including a person within section 1603(b)(4)) with knowledge that the person from whom he learns the fact is such a person, unless the Commission or a court finds that it would be inequitable, on consideration of the circumstances and the purposes of this Code (including the deterrent effect of liability), to treat the person within section 1603(b)(4) as if he were within section 1603(b)(1), (2), or (3).

143. Section 1602(a) of the ALI Proposal, supra note 142, provides:

SEC. 1602. (a) GENERAL.-It is unlawful for any person to engage in a fraudulent act or to make a misrepresentation in connection with (1) a sale or purchase of a security, an offer to sell or buy a security, or an inducement not to buy or sell a security, (2) a proxy solicitation or other circularization of security holders with respect to a security of a registrant, (3) a tender offer or a recommendation to security holders in favor of or opposition to a tender offer, or (4) any activity or proposed activity by an investment adviser with respect to a client or a prospective client.

Reporters to the Code note in comment $d$ to section 1603 that trading on material nonpublic information by outsiders is left to section 1602 and to "further judicial development." Id. $§ 1603$ comment d, at 663-64.

144. Chiarella, 445 U.S. at 239-40 (Burger, C.J., dissenting); see supra note 101.

145. Section 16A-Alternative A of the $A B A$ Task Force Report, supra note 63, provides: SUBSECTION (a). UNLAWful CONDUCT. It shall be unlawful, by use of any means or instrumentalities of interstate commerce, or of the mails, or any facility of any national securities exchange:

(1) Insiders-For an insider to sell or buy a security if he knows a fact that is material and nonpublic concerning the issuer or the security;

(2) Misappropriators-For any person to sell or buy any security if he knows a fact that is material and nonpublic concerning the issuer or the security, and he misappropriates such fact;

(3) Tippees-For a person to sell or buy a security if he learns a fact that he knows is material and nonpublic concerning the issuer or the security from an insider, fiduciary or a direct or indirect tippee of an insider or fiduciary or a direct or indirect tippee of an insider or fiduciary with the knowledge that the person from whom he learns the fact is an insider, fiduciary or a direct or indirect tippee of an insider or fiduciary;

(4) Tippers-For any insider, fiduciary or tippee of an insider or fiduciary to communicate to any other person a fact that is material and nonpublic concerning the issuer or the 
not define "misappropriation," but otherwise it went some distance toward defining the boundaries of legality.

security, knowing that such communication is likely to result in trading on the basis of material, nonpublic information; provided, however, that this subsection shall not apply to a communication made in good faith: $(A)$ to any person in connection with the performance by such person of his duties or obligations to the issuer; or (B) to any person pursuant to a requirement of any statute or rule or regulation promulgated thereunder.

SubSECTION (b). AFFiRMATIVE DEFEnSES-No person who purchases or sells a security ("trading person") shall be liable for violation of this Section if he sustains the burden that:

(1) Knowledge of the Trading Person or Other Party-(A) The other party to the transaction knew the fact; or (B) such trading person reasonably believed that the fact was public or was not material; or (C) the identity of the other party to the transaction (or his agent) was known to the trading person, and the trading person reasonably believed that the other party (or his agent) knew the fact.

(2) Institutional Traders-Such trading person is other than a natural person, and that (A) the individual making the investment decision on behalf of such trading person to purchase or sell any security, or to cause any such security to bc purchased or sold by or on behalf of others, did not know the material fact; and (B) such trading person had implemented one or a combination of policies and procedures, reasonable under the circumstances, taking into consideration the nature of the person's business, to ensure that an individual making investment decisions would not violate this Section, which policies and procedures may include, but are not limited to, (i) those which restricted any purchase, sale and causing any purchase and sale of any such security or (ii) those which prevent such individuals from knowing such information.

(3) Supervening Cause-The purchase or sale was caused solely by factors other than. the trading person's knowledge of the material fact.

SubSECTION (c). Definitions. For purposes of this Section:

(1) "Insider" means: the issuer; a director or officer of or a person controlling, controlled by, or under common control with, the issuer; a person who by virtue of his relationship or former relationship of trust or confidence to the issuer knows a material fact about the issuer or the security that is not generally available.

(2) "Misappropriate" means (A) to obtain material, nonpublic information by unlawful means, or (B) to appropriate material, nonpublic information to one's own use or benefit, or to the use or benefit of another person where, because of a fiduciary, contractual, employee or other relationship, one is under a duty not so to appropriate it.

(3) A fact is "material" if there is a substantial likelihood that a reasonable person would consider it important under the circumstances in determining his course of action, and (A) it would be likely on being made public to affect the market price of a security to a significant extent, or (B) a reasonable person would consider it especially important under the circumstances in determining his course of action in the light of such factors as degree of its specificity, the extent of its difference from public information, and its nature and reliability.

(4) A fact is "generally available" when such steps have been taken, and such time has elapsed, that it can be reasonably anticipated that the fact is or should be known to inter. ested investors in the relevant markets for the security in question.

(5) A "fact" includes (A) a promise, prediction, estimate, projection, or forecast, or (B) a statement of intention, motive, opinion, or law.

(6) "Knowledge," "knows," "knowing" and "knowingly" include conduct that is either knowing or reckless.

Subsection (d). Controlling Person Liability-(1) A person who controlled a person liable under this Section at the time of any act giving rise to liability is liable to the same extent as the controlled person; provided, however, that a controlling person is not liable under this Section if he proves that he reasonably did not know that the controlled person traded on the basis of or tipped material, nonpublic information; and (2) no person shall be liable for violating this Section solely by reason of employing another person who is so liable, if (A) there have been established procedures, and a system for applying such procedures, which would reasonably be expected to prevent and detect, insofar as practicable, any such violation by such other person, and $(B)$ such person has reasonably discharged the duties and obligations incumbent upon him by reason of such procedures and system without reasonable cause to believe that such procedures and system were nat being complied with. 
Sinnilar in scope to the ABA Task Force proposal were a draft bill submitted by Senator D'Amato and a substantially similar provision drafted by Milton V. Freeman and presented to Congress. ${ }^{146}$ These

SUBSECTION (e). CAUSING OR ASSISTING A VIOLATION-Any person who knowingly causes or gives substantial assistance to conduct by another person liable under this Section ("a principal") with knowledge that the conduct is unlawful or involves trading on the basis of or tipping material or nonpublic information is liable as a principal.

SURSECTION (f). BURDEN OF PROOF-No person shall be liable under this Section unless such liability is sustained by a preponderance of the evidence.

Subsection (g). Private Remedies in Face-to-Face Transactions . . . .

Subsection (h). Private Remedies in Market Transactions . . . .

Subsection (i). MEasure of Damages . . . .

SUBSECTION (j). TIPPERS AND TIPPEES-Any person who tips a fact that is material and not public in violation of Subsection (a)(4) to a tippee within the meaning of Subsection (a)(3) shall be liable under Subsections (g) and (h) to the same extent as the tippee.

SUBSECTION (k). COSTS . . . .

SuBSECTION (l). Penalties-(1) Whenever it shall appear to the Commission that any person has violated this Section in a transaction which is not part of a public offering by an issuer of securities other than standardized options, the Commission may, in addition to the remedies provided in Section 21 of this title, commence an action in a United States District Court to seek, and the court shall have jurisdiction to impose, a civil penalty to be paid by such person.

(2) The amount of such penalty shall be determined by the court in light of the facts and circumstances, but shall not exceed three times the profit gained or loss avoided as a result of such violation and shall be payable into the Treasury of the United States.

(3) If a person upon whom such penalty is imposed shall fail to pay such penalty within the time prescribed in the court's order, the Commission may refer the matter to the Attorney General, who may recover such penalty by action in the appropriate United States District Court. The Commission, by rule or regulation, may exempt from the provisions of this paragraph any class of persons or transactions.

(4) For purposes of this subsection, "profit gained" or "loss avoided" is the difference between the purchase or sale price of the security and the value of that security as measured by the trading price of the security a reasonable period after the fact becomes generally available.

SUBSECTION $(\mathrm{m})$. LiMTTATIONS-No damages may be awarded as provided in Subsections $(\mathrm{g})$ and $(\mathrm{h})$ of this Section, and no penalty may be imposed under Subsection $(l)$ of this Section for violations of this Section engaged in more than five years after the date of such violation.

SUBSECTION (n). EXCLUSIVITY - No action shall be maintained under Section 10(b) of this title for the conduct made unlawful herein, unless the defendant acts with an intent to deceive, manipulate or defraud.

ABA Task Force Report, supra note 63, app. A, at 259-63; see also id. app. B, at 263, reproduced supra note 141 (Task Force's alternative to its definition of unlawful conduct contained in subsection

(a) of Alternative A supra).

146. See 1984 Senate Hearings, supra note 14, at 8, 81 :

Draft of Legislation Proposed by Senator D'Amato

Sec. 1

Section 16(f). To Make Unlawful Unfair Use of Information.

(a) It shall be unlawful for any person who is in possession of material nonpublic information of such a character as may reasonably be expected immediately upon disclosure substantially to affect the price of the securities of such issuer to profit from such information or avoid loss by purchasing or selling such securities or any securities, convertible into or exchangeable for such securities or options or rights to obtain or dispose of such securities, or to aid and abet any such person so to profit or avoid loss, if he employs the information in violation of his own fiduciary or contractual obligations, or if to his knowledge the information is imparted to him in violation of the fiduciary or contractual obligations of the person imparting such information to him.

(b) Notwithstanding anything in paragraph (a) to the contrary, the following transactions shall not be in violations [sic] of paragraph (a) of this section:

(1) Purchases of any security described in paragraph (a) by a broker or by another agent on behalf of an offering person; or 
drafts premised liability on the misappropriation theory developed by the SEC in enforcement actions. ${ }^{147}$

Finally, the Securities Industry Association proposed a restrictive version of the prohibition against insider trading. Its draft limited the scope of unlawful use of inside information by prohibiting only the use of corporate, as opposed to market, information. This proposal did not penalize conduct to which the misappropriation theory applies, and thus would have eliminated some of the concern over the fuzzy edges of the law. ${ }^{148}$

(2) Sales by any person of any security described in paragraph (a) to the offering person.

(c) No person shall be subject to a sanction under subsection (a) of this section solely because that person aided and abetted a transaction covered by it in a manner other than by communicating material nonpublic information. Section 20 of this title shall not apply to actions brought under subsection (a) of this section. No person shall be liable under subsection (a) of this section solely by reason of employing another person who is liable under such subsection.

A person other than a natural person that employs another person who is liable under subsection (a) of this section shall not be liable if such person shows that:

(1) The individual making the investment decision on behalf of such person to purchase or sell any security described in subsection (a) did not know the material nonpublic information; or

(2) Such person had implemented one or a combination of policies and procedures, reasonable under the circumstances, taking into consideration the nature of the person's business, to ensure that individual(s) making investment decision(s) would not violate subsection (a), which policies and procedures may include, but are not limited to, (i) those which restrict any purchase or sale of any such security or (ii) those which prevent such individual(s) from knowing such information.

(d) It shall not be necessary to establish a violation of this Section $16(f)$ that the acts made unlawful be proved to be done with any purpose to deceive, manipulate or defraud investors but only that the use of information was unfair as violating an express or implied obligation.

(e) Any person violating this section shall forfeit the amount of the profit gained or the loss avoided and shall pay an amount determined by the court in light of the facts and circumstances up to three times the amount of the profit gained or the loss avoided into the Treasury of the United States upon order of a United States District Court in an action commenced by the Commission under Section 21(a).

For purposes of this paragraph "profit gained" or "loss avoided" is the difference between the purchase or sale price of the security and the value of that security as measured by the trading price of the security a reasonable period after public dissemination of the nonpublic information.

(f) This section is in addition to any other provision of law and, particularly, shall not be deemed in any way to restrict the scope of sections 10(b) and 14(e) of this Act and the rules promulgated thereunder.

147. See supra note 146.

148. The Securities Industry Association's Federal Regulation Committee's Draft, 1983 House

Hearings, supra note 14, at 220, provides:

2) Whenever it shall appear to the Commission that any person . . . has knowingly purchased or sold . . . or caused to be purchased or sold, a security, based on material nonpublic corporate information in a transaction (i) on or through the facilities of a national securities exchange or from or through a broker or dealer, and (ii) which is not part of a public offering by an issuer of securities other than standardized options, and that such purchase or sale . . . violated Section $78 \mathrm{j}(\mathrm{b})$ or $78 \mathrm{n}(\mathrm{e})$ of this title or the rules or the regulations thereunder, the Commission may bring an action within . . . two years from the date of such purchase or sale in a United States District Court to seek, and the court shall have jurisdiction to impose, upon finding the existence of such a . . . violation, a civil penalty to be paid by such person .... The amount of such penalty and the person or persons 
Each of these proposals had inherent weaknesses. Some were rejected as too broad, others as too narrow. A narrow definition, like that of the Securities Industry Association, would have hindered the SEC's enforcement activities, and so worked against Congress's very purpose in adopting the ITSA. ${ }^{149}$ Moreover, the Commission was concerned that a narrow definition in the ITSA would be applied in cases other than those in which the SEC sought treble damages under the ITSA. ${ }^{150} \mathrm{~A}$ broad definition, such as that proposed by Senator D'Amato, would have had the benefit of not restricting the SEC's enforcement function, but would have done little to add clarity and predictability to the law. ${ }^{151}$ Any definition would introduce new terms that could give rise to ambiguities and, thus, litigation. This potential for injecting additional uncertainty into the law governing insider trading weighed heavily against the merits of any of the proposed definitions. ${ }^{152}$

Still, a definition would have been helpful and elucidative. In the area of what traditionally has been prohibited insider trading-cases in which an insider trades on the basis of material nonpublic informationdefining the prohibited conduct would not have been difficult. ${ }^{153}$ The proposed ALI Federal Securities Code contams such a definition. ${ }^{154}$ In cases outside the sphere of this activity, defining the prohibited conduct would have put to rest the issue of the validity of the misappropriation

against whom the penalty shall be assessed shall be determined by the court in light of the facts and circumstances, but the amount of such penalty imposed ... shall not in the aggregate exceed three times the profit gained or loss avoided by . . . such person as a result of such unlawful purchase or sale, and shall be payable into the Treasury of the United States. If a person upon whom such a penalty is imposed shall fail to pay such penalty within the time prescribed in the court's order, the Commission may refer the matter to the Attorney General who may recover such penalty by action in the appropriate United States District Court. The actions authorized by this paragraph may be brought in addition to any other actions that the Commission or the Attorney General are entitled to bring. . . . For purposes of Section 27 of this title, actions under this paragraph shall be actions to enforce a liability or a duty created by this title. The Commission, by rule or regulation, may exempt from the provisions of this paragraph any class of persons or transactions.

(emphasis added).

See also Karsch, The Insider Trading Sanctions Act: Incorporating A Market Information Definition, 6 J. Comp. Bus. \& CAPiTAl MARKET L. 283, $294-97$ (1984) (discussing Great Britain's attempt to regulate insider trading).

149. See House REPORT, supra note 31 , at 8-9.

150. See 1983 House Hearings, supra note 14, at 54-57 (statement of Rep. Wirth).

151. See id. at 238-42 (statement of Ted J. Fiflis).

152. "[T]here is the legitimate concern that a deflnition with new terms and its legislative history would create new ambiguities, thereby increasing rather than limiting uncertainty. This will mean a decade of vigorous and expensive litigation over the new terms used by Congress." 1984 Senate Hearings, supra note 14, at 36 (statement of John Fedders).

153. See, e.g., 1983 House Hearings, supra note 14, at 51 (comment of SEC Chairman Shad) ("II]n my opinion it would be possible to define who is an insider and what would be involved in both company and market information.")

154. See, e.g., ALI Proposal $\S 1603$, supra note 142. 
theory. Views expressed in the legislative history of the Act suggest that Congress considered unlawful any use of material nonpublic information that was obtained by illegitimate means. ${ }^{155}$ Given that clear expression of intent and the prevailing criticism of the misappropriation theory, it would have been desirable to eliminate questions about the scope of the law by doing more than adopting a new remedy. The definition could have given validity to the misappropriation theory and resolved some of the issues relating to its application. While it is true that any definition included in the ITSA might have lacked the flexibility necessary to encompass a novel theory of liability that the Commission might put forth in an enforcement action, the SEC could have reverted to reliance on section 10(b) and Rule 10b-5 in such a case. Furthermore, using the ITSA to support novel theories of liability may be inappropriate. ${ }^{156}$ Since the ITSA authorizes a penalty for the prohibited conduct, one may cogently argue for a clear definition of what is prohibited, even if the scope of prohibited conduct is slightly narrower than the scope of the judicially interpreted implied cause of action.

Without a definition of insider trading to resolve uncertainties about what uses of material nonpublic information are unlawful, the ITSA's treble damages sanction could be imposed when the defendant did not and could not have known that his conduct violated the federal securities laws. Imposing the penalty under such circumstances raises concerns about fair notice and efficiency of regulation. ${ }^{157}$ There are two aspects to

155. See, e.g., 1984 Senate Hearings, supra note 14, at 2 (statement of Sen. D'Amato); id. at 32 35 (comments of Sen. D'Amato and John Fedders). The Committee intentionally left the judicial development of what constitutes insider trading undisturbed for fear that a statutory definition would either have little effect or would create "gaping holes" through which traders engaged in questionable activities could escape. Concerns over limiting the definition of insider trading, remedying the Court's narrow interpretation of existing law in Dirks, 463 U.S. 646 (1983), and leaving unimpaired "legitimate business transactions" imply that Congress intended to outlaw profitablc use of material nonpublic information gained by any illicit means. See HouSE REPORT, supra note 31, at 13-15, 13 n.20 (supporting misappropriation theory as used in United States v. Newman, 664 F.2d 12 (2d Cir. 1981), cert. denied, 464 U.S. 863 (1983)); see also Newman, 664 F.2d at 22 n.34 (SEC comments).

156. See infra notes $157-89$ and accompanying text.

157. See Chiarella, 445 U.S. at 235 n.20 (Reacting to Justice Blackmun's dissent, the Court said, "[A] judicial holding that certain undefined activities 'generally are prohibited' by $\S 10(\mathrm{~b})$ would raise questions whether either criminal or civil defendants would be given fair notice that they have engaged in illegal activity.") (citation omitted); see also 1983 House Hearings, supra note 14, at 52 (comments of Sen. Rinaldo, SEC Chairman Shad and John Fedders); id. at 289 (statement of Michael R. Klein) (indicating lack of clarity in the law of insider trading); Freeman, Legislative Action Called "Desirable" for Resolution of Insider Trading Problems, 10 S.E.C. "82, reprinted in 1983 House Hearings, supra note 14, at 187, 193-94 ("In any event to use the securities laws to protect the reputation of bankers where no investors appear to have been cheated seems like a sufficiently unusual application of the statute designed to protect investors to raise questions about whether the criminal law is an appropriate weapon to that effect, especially if it be conceded that there must be by statute a 'clear and definite statement of the conduct proscribed.' See [United 
the concern that fair notice of the scope of prohibited conduct be given before a defendant is subjected to a treble damages penalty for insider trading. First, due process requires that a law be sufficiently clear to provide notice to a reasonable person of the standard of illegitimate conduct. ${ }^{158}$ The due process requirement of notice underlies the void-forvagueness doctrine, by which a court must hold void any statute or legal rule that fails adequately to articulate an ascertainable standard of prohibited conduct. A statute or rule may be void on its face if it fails to give adequate notice of what is proscribed. ${ }^{159}$ Alternatively, while not ambiguous on its face, a rule or statute may be found to violate due process as applied to a specific fact situation. ${ }^{160}$

Section $10(\mathrm{~b})$ and Rule 10b-5 have withstood attacks of facial invalidity based on the void-for-vagueness doctrine, ${ }^{161}$ but the doctrine nonetheless might prevent their application to a defendant in a specific case. If liability were based upon an unanticipated and drastic departure from existing law governing the standards of illegal activity, due process considerations would come into play to protect the defendant from liability based on lack of notice of the new legal principle. ${ }^{162}$ Of course, to violate due process the departure from precedent would have to be somethimg other than a logical extension of previous articulations of the law. For example, the void-for-vagueness doctrine would have applied in Chiarella if liability in that case had been premised on the discrepancy between Chiarella's and the investors' access to confidential information, as suggested by Justice Blackmun's dissent. ${ }^{163}$

States v. Persky,] 520 F.2d 283, 288 (2d Cir. 1975)."); Karsch, supra note 148, at 291 (if treble damages penalty of ITSA "[is] to be fairly applied, then traders should have notice of what constitutes a violation").

158. See, e.g., Connally v. General Constr. Co., 269 U.S. 385, 391 (1926).

159. See, e.g., Coates v. City of Cincinnati, 402 U.S. 611,616 (1971) (holding invalid, as vague on its face, ordinance that made it criminal offense for "three or more persons to assemble . . . on any of the sidewalks . . . and there conduct themseives in a manner annoying to persons passing by").

160. See, e.g., Palmer v. City of Euclid, 402 U.S. 544, 546 (1971) (holding "suspicious person" ordinance void as applied).

161. United States v. Persky, 520 F.2d 283, 287 (2d Cir. 1975).

162. See supra notes $159-60$ and accompanying text; see infra note 163 .

163. Justice Blackmun would have held that Chiarella's access to the material nonpublic information gave rise to a duty not to use such information for his personal gain. He stated, "I would hold that persons having access to confidential material information that is not legally available to others generally are prohibited by Rule $10 \mathrm{~b}-5$ from engaging in schemes to exploit their structural informational advantage through trading in affected securities." Chiarella, 445 U.S. at 251 (Blackmun, J., dissenting).

The majority in Chiarella expressed concern that Justice Blackmun's suggested standard of illegal conduct would violate the void-for-vagueness doctrine: "Additionally, a judicial holding that certain undefined activities 'generally are prohibited' by $\S 10(b)$ would raise questions whether either criminal or civil defendants would be given fair notice that they have engaged in illegal activity." $I d$. 
Apart from due process considerations, a court in an individual case may protect a defendant from an abrupt change in the law by refusing to apply the newly created rule retroactively. The nonretroactivity doctrine is not founded on the Constitution, but rests instead on notions of fundamental fairness. ${ }^{164}$ Like the due process requirement of notice, the nonretroactivity doctrine has been applied in civil as well as criminal cases. ${ }^{165}$

In the criminal context, if a case announces a new rule and the rule is "a clear break with the past," 166 the court will consider "the extent of the reliance by law enforcement authorities on the old standards, and . . . the effect on the administration of justice of a retroactive application of the new standards." 167 "Once the Court has found that the new rule was unanticipated, the second and third . . . factors-reliance by law enforcement authorities on the old standards and effect on the administration of justice of a retroactive application of the new rule-have virtually compelled a finding of nonretroactivity."168

In the civil context, courts consider three factors. First, if the decision is to be applied only prospectively, it must establish "a new principle of law."169 Second, the court must determine the purpose of the new rule of law and whether retroactive application "will further or retard its operation."170 Third, the court must assess the hardship resulting from a retroactive application of the new rule. ${ }^{171}$

An example of a criminal case in which the issue of nonretroactivity

at 235 n.20 (citation omitted). See generally Note, Due Process Requirements of Definiteness in Statutes, 62 HARV. L. REv. 77 (1948).

164. United States v. Johnson, 457 U.S. 537, 542 (1982). On the nonretroactivity doctrine, see generally R. MCNamara, Constitutional Limitations on Criminal Procedure $\S 1.04$ (1982); Mishkin, The Supreme Court, 1964 Term Foreword: The High Court, The Great Writ, and the Due Process of Time and Law, 79 HARv. L. REv. 56 (1965); Schwartz, Retroactivity, Reliability, and Due Process: A Reply to Professor Mishkin, 33 U. CHI. L. Rev. 719 (1966); Note, Prospective Overruling and Retroactive Application in the Federal Courts, 71 YALE L.J. 907 (1962).

165. See Chevron Oil Co. v. Huson, 404 U.S. 97, 106 (1971).

166. Desist v. United States, 394 U.S. 244, 248 (1969).

167. Stovall v. Denno, 388 U.S. 293, 297 (1967). The Court in Stovall articulated the initial inquiry as "the purpose to be served by the new standards," $i d$. at 297; in United States v. Johnson, 457 U.S. 537, 551-54 (1982), the Court seemed to reformulate this initial inquiry to consist of an analysis of the degree to which the new rule broke with the past. In Johnson, however, the Court did consider whether the new rule was aimed at furthering the truth-finding aspects of trial, id. at 555, and presumably would have applied the rule retroactively to the case at bar had it answered that question in the affirmative.

168. United States v. Johnson, 457 U.S. 537, 549-50 (1982) (citations omitted).

169. Chevron Oil Co. v. Huson, 404 U.S. 97, 106 (1971). The new principle may arise as a result of "overruling clear past precedent on which litigants may have relied, . . . or by deciding an issue of first impression whose resolution was not clearly foreshadowed." Id. (citations omitted).

170. Id. at 107 (citing Linkletter v. Walker, 381 U.S. 618,629 (1965)).

171. $I d$. 
might have appropriately been raised is United States $v$. Newman. ${ }^{172}$ Newman was one of three co-conspirators convicted for engaging in insider trading on the basis of information gained from an investment banking firm, Morgan Stanley, about proposed mergers and acquisitions. The three co-conspirators purchased stock in companies that were targets of acquisitions proposed by Morgan Stanley's clients, and profited by using the information about the proposed transactions before the acquisitions were publicly announced. Newman's conduct closely resembled Chiarella's: Chiarella used information gained from his employer; Newman, from his co-conspirator's employer; and neither had any relationship to other traders in the securities.

Although Justice Stevens had discussed the misappropriation theory in his concurrence in Chiarella, prior to Newman the theory had never provided a basis for either civil or criminal liability under section 10(b) and Rule 10b-5. Likewise, although long-standing principles of agency law recognized the duty of an employee to his employer not to use confidential information for personal gain, ${ }^{173}$ prior to Newman breach of that duty had never afforded grounds for liability under the securities laws. In fact, the Court in Chiarella-like Newman, a criminal case-emphasized that under section 10(b) one's duty was to those purchasing or selling securities at the same time in the market. ${ }^{174}$ Obviously, Newman owed no duty to purchasers and sellers of the stock in which he traded since he had no relationship to them. ${ }^{175}$ Nonetheless, the court found that the purchaser/seller requirement related merely to the issue of standing, and so did not pertain in a criminal prosecution. ${ }^{176}$ The court had no difficulty switching its focus from a duty owed to other shareholders to one owed to a nonshareholder-employer as the basis for liability under section $10(b)$.

The question of retroactivity apparently was not raised in Newman, ${ }^{177}$ but the case was an appropriate one in which to apply the nonretroactivity doctrine. The court announced a new rule: The basis of a

172. 664 F.2d 12 (2d Cir. 1981), cert. denied, 464 U.S. 863 (1983); cf. Note, supra note 124, at 864-65 (criticizing Newman as a violation of due process notice).

173. See supra note 105 and accompanying text.

174. See supra notes 54-56 and accompanying text (discussing Chiarella).

175. Newman, 664 F.2d at 16 (footnote omitted):

We hold that appellee's conduct . . could be found to constitute a criminal violation of section 10(b) and Rule 10b-5 despite the fact that neither Morgan Stanley, Kuhn Loeb nor their clients was at the time a purchaser or seller of the target company securities in any transaction with any of the defendants."

176. Id. at 17 ("The district court's statement that fraud perpetrated upon purchasers or sellers of securities is a 'requisite element under the securities laws' is, therefore, an overbroad and incorrect summary of the law.").

177. The court implicitly rejected a due process claim of inadequate notice. $I d$. at 19. 
breach of duty under section 10 (b) could be a duty owed to a person whom the defendant's conduct did not deceive in relation to a trading decision. ${ }^{178}$ The reliance concern of retroactivity is inapposite here, because enforcement officials did not rely on the preexisting state of the law in the investigation process. ${ }^{179}$ Finally, the effect of nonretroactivity on the administration of justice would have been negligible in Newman. The rule would have deterred future misconduct equally well if not applied to Newman, although, of course, Newman himself would have been freed. ${ }^{180}$ Balancing an individual's interest in having notice of the law against the government's interest in penalizing illegal behavior, the protection of the individual should prevail in a case like this, in which only a financial wrong has been done and no private claim of injury has been made.

If Newman had been a civil action for treble damages under the ITSA, an argument for nonretroactivity also might have prevailed. In such a case, the civil standard for determining when a decision should not operate retroactively would govern, since the ITSA purports to impose a civil sanction. ${ }^{181}$ The legal principle on which liability was based in Newman created an unprecedented change in the standards of legitimate conduct, and thus the first factor in the analysis is satisfied. The second consideration relevant to the issue of nonretroactivity in a civil action is whether a nonretroactive application of the new principle of law will further or retard the purpose of the new rule. The purpose of the misappropriation theory is to deter a broadened sphere of activity. ${ }^{182}$ Deterrence has two aspects: specific deterrence of an identified individual, and general deterrence of potential violators of the law. ${ }^{183}$ Although

178. The newness of the rule was discussed by the district court in United States v. Courtois, [1981] FED. SEC. L. REP. (CCH) \ 98,024, at 91,296 (S.D.N.Y. June 5, 1981), rev'd sub nom. United States v. Newman, 664 F.2d 12 (2d Cir. 1981), cert. denied, 464 U.S. 863 (1983):

I conclude that there was no 'clear and definite statement' in the federal securities laws which both antedated and proscribed the acts alleged in this indictment. As of the times alleged, neither courts, commentators, nor the SEC in its rule-making or enforcement capacities had stated that Rule $10 \mathrm{~b}-5$ extended to a noninsider's breach of a fiduciary duty owed to the acquiring corporation in a tender offer.

See also Chiarella, 445 U.S. at 235 n.20.

179. Reliance by law enforcement officials might be significant in a case involving an issue of search and seizure under the fourth amendment. See, e.g., United States v. Johnson, 457 U.S. 537, 549-50 (1982).

180. Newman still could have been subject to a civil enforcement action by the Commission pursuant to section 21 of the 1934 Act, 15 U.S.C. $\S 78 \mathrm{u}(\mathrm{a})$ (1982).

181. But see infra notes $248-69$ and accompanying text (discussing possibility that ITSA's sanction is criminal, not civil).

182. That is, the misappropriation theory is used to enlarge the sphere of activity that is prohibited by Rules $10 \mathrm{~b}-5$ and $14 \mathrm{e}-3$.

183. For a description of general and specific deterrence see W. LAFAVE \& A. ScotT, CrimlNAL LAW 22-23 (1972) (discussing "general" and "particular" deterrence). 
a nonretroactive application of the misappropriation theory would not serve the purpose of specific deterrence, it would further the goal of general deterrence. Nonretroactive application would leave Newman unpunished by the treble damages penalty for his conduct, but would place other potential violators on notice of the broader reach of Rule 10b-5. Moreover, the hardship that would result from a retroactive application of the new rule might be significant in financial terms. Finally, defendants whose conduct violates previously unarticulated legal principles do not necessarily act with the degree of culpability sufficient to warrant the deterrence intended by the ITSA. ${ }^{184}$ In contrast, if the SEC seeks and obtains disgorgement rather than a penalty, the defendant suffers less financial hardship. Therefore, a retroactive application of the new theory of liability might be appropriate in actions for disgorgement but inappropriate in actions for assessment of the ITSA's penalty. ${ }^{185}$

As a result of the uncertainty in the law about what constitutes unlarvful insider trading and the absence of a definition of the prohibited conduct in the ITSA, a defendant inay incur liability without fair notice that his conduct was illegal. When a reasonable person in the defendant's position would not have known that his conduct violated the insider trading laws, and when the defendant in fact did not know that his activity was illegal, the imposition of the treble dainages penalty raises the questions whether due process prohibits liability and whether application of the nonretroactivity doctrime would be appropriate. ${ }^{186}$

184. In other words, the defendants did not know the legal boundaries, and therefore did not realize that their conduct was unlawful. See infra text accompanying notes 278-86.

185. Even though the rule of liability would still be unprecedented, the burden resulting from a retroactive application of the new rule would be less significant if only disgorgement was sought. This decrease in the burden might be enough to shift the balance in favor of a retroactive application of the new rule. See Committee on Legislation, New York State Bar Association, Report of Antitrust Section, 54 N.Y. ST. B.J. 395 (1982) (recommending only single, instead of treble, damages for antitrust violations where reasonable person could not have known that defendant's conduct violated law; Committee indicated that " 'foreseeability' may be lacking where the law has changed or where there is substantial disagreement among judicial bodies") [hereinafter cited as N.Y. State Bar Antitrust Report]; 1983 House Hearings, supra note 14, at 52 (statement of Rep. Rinaldo) ("What you are telling us is that under the present scheme of things, absent this legislation [ITSA], no definition is necessary because in effect the only result, when a person is guilty of insider trading, can be disgorgement. There is no punitive penalty."); see also Anderson, supra note 124, at 374-77 (concluding that Chiarella was correctly decided, because the class to which Chiarella belonged, financial printers, does not generally have control over the timing and content of a corporation's disclosure, nor does such class generally deal with investing public in a way that inspires trust). Professor Anderson would limit the class of persons subject to liability for insider trading to corporate insiders and market professionals. Therefore, Newman might be covered by her theory, since he was an employee of an investment banking firm and thus a member of the securities industry. See id.

186. An analogy between the civil liability provisions of the antitrust laws and the 1TSA might be drawn. Section 4 of the Clayton Act, 15 U.S.C. $\$ 15$ (1982), provides that "any person who shall be injured in his business or property by reason of anything forbidden in the antitrust laws may sue therefor . . . and shall recover threefold the damages by him sustained, and the cost of suit, includ- 
Courts should liberally apply these doctrines to protect defendants from the treble damages penalty of the ITSA, because other enforcement mechanisms will still be available against such defendants. For example, if the nonretroactivity doctrine precludes assessment of treble damages in a particular case, the defendant can still be required to disgorge the profits. Furthermore, by announcing the new rule of liability, courts will be serving the general deterrence purpose of the Act. Thus, even though application of these doctrines may permit certain defendants "one free bite," it does not unduly burden the enforcement efforts of the Commission. At the same time, it protects defendants from arbitrary punishment. Moreover, imposition of the penalty based on a novel legal principle fulfills no specific deterrence purpose; defendants cannot alter their behavior as a result of the threat of a treble damages penalty that they cannot foresee.

Predicating liability for treble damages on a novel approach to the law regulating insider trading not only offends fair notice doctrines, it is also an inefficient method of regulation. Although it deters the conduct that the legislature intended to prohibit, it might also deter other conduct considered lawful by the legislature. Persons uncertain of the scope of the prohibited conduct might forego lawful action out of fear that their assessment of the conduct's legality was inaccurate. "[In the absence of] clarity concerning the conduct to which the penalty applies, legitimate activity may be foregone, and heavy compliance expenses incurred, all ultimately as costs borne by the investing public."187 Thus, it is inefficient and costly to punish activity that is not clearly prohibited. Moreover, the lack of a definition of insider trading may discourage a person charged with unlawful activity and faced with the possibility of having to pay treble damages from litigating legitimate factual issues. Instead, the defendant may be overly encouraged to settle the case for an amount less

ing a reasonable attorney's fee." Several significant distinctions between the ITSA and section 4 of the Clayton Act are immediately apparent. First, section 4 authorizes treble damages recovery for a private plaintiff, whereas under the ITSA the penalty is not available to individuals injured by the illegal trade. See supra notes $79-80$ and accompanying text. Second, treble damages are mandatory under section 4, whereas the amount of the penalty is discretionary under the ITSA. Sec infra notes 241-47 and accompanying text. The Supreme Court has recognized that treble damages under the antitrust laws may be inappropriate when new decisions "constitute a sharp break in the line of earlier authority, or an avulsive change which causes the current of the law thereafter to flow between new banks." Hanover Shoe v. United Shoe Mach. Corp., 392 U.S. 481, 499 (1968); see also Easterbrook, Detrebling Antitrust Damages, 28 J.L. \& EcoN. 445 (1985); N.Y. State Bar Antitrust Report, supra note 185, at 385 (recommending that the law "be amended to limit the remedy [under section 4 of the Clayton Act] to single damages where a defendant could not reasonably have known it was violating the law").

187. 1983 House Hearings, supra note 14, at 41 (memorandum to Chairman Shad from the Office of the General Counsel of the SEC). The maximum criminal monetary penalty under section 32, 15 U.S.C. $\$ 78 f$ (Supp. Il 1984), is $\$ 100,000$. 
than three times the amount of the profit gained or loss avoided. ${ }^{188}$ Hasty settlements prompted by the ambiguity of the prohibited sphere of activity ultimately chill legitimate behavior of others and cause payment by those who have not violated the law and who should not be deterred from engaging in similar conduct in the future. ${ }^{189}$

\section{Standard of Proof.}

The ambiguity of the definition of unlawful insider trading is compounded by the minimum standard of proof that Congress prescribed for actions under the ITSA. In the legislative history of the ITSA, Congress stated that the burden of proof in a treble damages action should be "a preponderance of the evidence," the burden normally applicable in civil litigation. ${ }^{190}$

The SEC had proposed this standard during the congressional committee hearings on the Act. Prior to enactment of the ITSA the preponderance of the evidence standard applied in private civil actions for violations of the securities laws as well as in suits by the SEC for injunctive relief. ${ }^{191}$

The Commission urged two reasons why this standard was appropriate in cases brought under the ITSA. First, the preponderance of the evidence standard is consistent with the purpose of increasing deterrence. A higher standard of proof makes it more difficult for the Commission to succeed in an enforcement action. ${ }^{192}$ Congress found this argument compelling and cited it as its reason for deeming the preponderance standard

188. See Proceedings of the SEC Major Issues Conference 42 (June 28-29, 1984) (teport of comments of Professor Homer Kripke on the ITSA):

Professor Kripke expressed concern, however, regarding the treble damage proposal. The mere prospect of a treble damage proceeding will chill a prospective defendant's willingness to litigate legitimate factual issues, such as whether information was material or nonpublic, or legitimate legal issues. Without a definition of insider trading, both the staff and the respondent know that the risks to the respondent of litigating will be much greater than negotiating a consent decree.

189. The defendant whose conduct was not unlawful should not be discouraged. See 1983 House Hearings, supra note 14, at 29 (statement of SEC Chairman Shad) ("In order to avoid the imposition of unintended compliance expenses, which are ultimately borne by the investing public, the Commission recognizes the need for legislation to be clear, unambiguous and predictable in its interpretation and application.")

190. HouSE REPORT, supra note 31, at 15 (1983) (footnote omitted):

Some commentators expressed the view that, in light of the potential for a large penalty, the appropriate burden of proof . . . should be more than the "preponderance of the evidence" standard applicable to Commission injunctive actions. The Committee rejects this notion because a higher proof standard could hamper Commission penalty actions.

191. See Herman \& MacLean v. Huddleston, 459 U.S. 375, 387 (1983).

192. See 1983 House Hearings, supra note 14, at 46 (memorandum from the Office of the General Counsel of the SEC to Chairman Shad):

A higher burden of proof, such as a clear and convincing standard, would make it more difficult for the Commission to prove its case, particularly in insider trading cases where 
applicable. ${ }^{193}$ Second, the Commission expressed concern that a trial could become confusing if two standards applied in a single factual situation: preponderance of the evidence to requests for injunctive and disgorgement relief, and a higher standard to the request for the treble damages penalty. ${ }^{194}$ Such a dual standard in a single case could indeed cause confusion by requiring inconsistent judgments whenever the SEC proves its case by a preponderance of the evidence but no more. Only a district court judge, however, not a jury, would need to apply both standards, for there is no right to a jury trial on the disgorgement and injunction claims. ${ }^{195}$ Because a judge would be intimately familiar with the difference in the two standards of proof, the concern about confusion is negligible.

There are, in contrast, significant reasons why a preponderance of the evidence may be too low a standard for imposing a treble damages penalty. The burden of proof constitutionally required in a civil or criminal proceeding is determined by reference to due process considerations: 196

The function of a standard of proof, as that concept is embodied in the Due Process Clause and in the realm of factfinding, is to "instruct the factfinder concerning the degree of confidence our society thinks he should have in the correctness of factual conclusions for a particular type of adjudication." The standard serves to allocate the risk of error between the litigants and to indicate the relative importance attached to the ultimate decision. ${ }^{197}$

Thus, the preponderance of the evidence standard, the burden generally imposed in actions for monetary damages between private litigants, refiects society's minimal concern about the outcome of such suits. ${ }^{198}$ It

most cases are built on circumstancial [sic] evidence. A higher standard of proof would therefore substantially reduce the deterrent impact of the proposed sanction.

See also id. at 62-64 (comments of Rep. Dingell and John Fedders); id. at 95-96 (letter from SEC Chairman Shad to Rep. Wirth).

193. See supra note 192.

194. See 1983 House Hearings, supra note 14, at 97 (letter from Chairman Shad to Rep. Wirth).

195. See infra notes $225-38$ and accompanying text.

196. U.S. CONST. amend. V. On the issue of the standard of proof, see generally Kadish, Meth. odology and Criteria in Due Process Adjudication-A Survey and Criticism, 66 Y ALE L.J. 319 (1957); McBaine, Burdens of Proof: Degrees of Belief, 32 CAL1F. L. Rev. 242, 251-58 (1944).

197. Addington v. Texas, 441 U.S. 418, 423 (1979) (quoting In re Winship, 397 U.S. 358, 370 (1970) (Harlan, J., concurring) (citation omitted)).

198. Addington, 441 U.S. at 423. For common law fraud, which is similar to an action under Rule 10b-5, the appropriate burden is proof by clear and convincing evidence. See, e.g., Fox v. Kane-Miller Corp., 542 F.2d 915, 918 (4th Cir. 1976) (jury to find proof of fraud only upon clear and convincing evidence); C. MCCORMICK, HANDBOOK OF THE LAW OF EvIDENCE $\$ 340$, at 796. 97 (E. Cleary 3d ed. 1984). But see Household Fin. Corp. v. Altenberg, 5 Ohio St. 2d 190, 193, 214 N.E.2d 667, 669 (1966) (in civil case where money damages are sought, proof of fraud by preponderance of the evidence will suffice). Cases brought under the False Claims Act, 31 U.S.C. $\$ \S 3729$. 3731 (1982), also must be proven by clear and convincing evidence. United States v. Ekelman \& 
allocates the risk of an erroneous judgment almost equally between plaintiff and defendant. In contrast, the highest burden of proof, "beyond a reasonable doubt," applies in criminal actions, reflecting society's great concern that judgments involving possible loss of liberty or life be accurate. ${ }^{199}$

An intermediate standard of proof, requiring that the defendant's guilt be proven by clear and convincing evidence, has been required in cases in which the interests at stake are deemed to be "more substantial than mere loss of money."200 For example, due process may require this intermediate burden when an adverse judgement would injure the defendant's reputation. ${ }^{201}$

In Santosky v. Kramer, ${ }^{202}$ the Supreme Court articulated three factors to be assessed in determining the appropriate burden of proof: "the private interests affected by the proceeding; the risk of error created by the . . . chosen procedure; and the countervailing governmental interest supporting use of the challenged procedure."203 If these three factors are applied to a hypothetical case in which treble damages are sought pursuant to the ITSA, they indicate that the clear and convincing evidence standard, rather than the preponderance standard, should be used.

The first consideration focuses on the private interest at stake in the proceeding. In an action under the ITSA, the most obvious potential deprivation at stake is the "damage to the defendant's pocketbook."204 The Act authorizes courts to assess a potentially devastating sum, up to three times the amount of profit gained or loss avoided on the illegal trade. Indeed, in many cases this amount could exceed the inaximum criminal fine allowed for the same conduct. ${ }^{205}$ Even when the court exercises its discretion under the Act to assess a penalty less than the maximum ainount, ${ }^{206}$ the impact of the penalty will almost certainly be

Assocs., 532 F.2d 545, 548 (6th Cir. 1975); Hageny v. United States, 570 F.2d 924, 933 (Ct. Cl. 1978).

199. Addington v. Texas, 441 U.S. $418,423-24$ (1979).

200. Id. at 424 (articulating middle standard of proof as "clear," "cogent," "unequivocal," and "convincing").

201. Id.

202. 455 U.S. 745 (1982). Santosky decided what standard of proof was required when the state (there, New York) sought to terminate parental rights upon a finding of neglect. Id. at 752-70.

203. Id. at 754 (citing Lassiter v. Department of Social Servs., 452 U.S. 18, 27-31 (1981)).

204. Wheeler, The Constitutional Case for Reforming Punitive Damages Procedures, 69 VA. L. REV. 269, 278 (1983).

205. The maximum criminal monetary penalty under the 1934 Act as amended by the Insider Trading Sanctions Act of 1984, 15 U.S.C. $\$ 78 f($ a) (Supp. II 1984), is $\$ 100,000$; see also Coffee, Regulating the Market for Corporate Control: A Critical Assessment of the Tender Offer's Role in Corporate Governance, 84 CoLum. L. REv. 1145, 1158 (1984) ("[T] he goal of policy planning should be to optimize the level of deterrence, not maximize it.").

206. 15 U.S.C. \& $78 f f(a)$ (Supp. II 1984). 
significant.

In addition to the potential financial loss in an action under the ITSA, damage to the defendant's reputation is also likely to result from an adverse judgment. It has been argued that any defendant in a private civil action who is judged to owe punitive as well as compensatory damages will suffer stigma as a result of the judgment. ${ }^{207}$ Punitive damages are awarded in private tort actions only upon a finding of scienter or recklessness, which evidences the culpability of the defendant. ${ }^{208}$ The very name of the award implies the intent to punish and suggests that a defendant found liable for punitive damages deserves punishment. ${ }^{209}$

A similar loss of reputation is at stake when the Commission seeks the treble damages penalty under the ITSA. Like liability for punitive damages, liability for the ITSA's penalty represents a finding that the defendant deserves punishment. ${ }^{210}$ Both depend on proof of scienter or recklessness. ${ }^{211}$ Moreover, the SEC and Congress dubbed inside traders "thieves," 212 an epithet certainly more characteristic of criminal than of civil defendants. And that the plaintiff in an ITSA action is a governmental agency rather than a private citizen makes the case that stigmatization results from liability even stronger. The SEC has vowed to devote increased attention and resources to enforcement of the insider trading laws, and the consequences of its enforcement efforts have been increasingly publicized. ${ }^{213}$ These additional factors prove that the concern for

207. Wheeler, supra note 204 , at 280 ("The defendant has more to lose in a punitive damages proceeding, however, than the monetary penalty he may be ordered to pay. An adverse judgment will also stigmatize him.").

208. Id. at $282 \&$ nn.66-73.

209. Id. at 282 ("Thus, a punitive damages award, unlike a compensatory award, seems always to constitute a 'badge of disgrace' and to jeopardize the defendant's good name, reputation, honor, and integrity.").

210. See House RePORT, supra note 31, at 8 (1983) ("The Committee believes the new penalty provided by the legislation will serve as a powerful deterrent to insider trading abuses.").

211. See supra notes $\mathbf{1 2 7 - 2 8}$ and accompanying text.

212. "We must provide a sufficient deterrent so that people will think twice before they engage in what all of us would call thievery." (emphasis added) 1983 House Hearings, supra note 14, at 2 (statement of Rep. Wirth); see also id. at 61. The term originates from Chief Justice Burger's dissent in Chiarella, where he stated, "In sum, the evidence shows beyond all doubt that Chiarella, working literally in the shadows of the warning signs [of his employer] in the printshop misappropriatedstole to put it bluntly-valuable nonpublic information entrusted to him in the utmost confidence." Chiarella, 445 U.S. at 245 (Burger, C.J., dissenting) (emphasis added).

213. See 1983 House Hearings, supra note 14, at 18 (statement of SEC Chairman Shad) ("In order to curtail and deter insider trading, the Commission has sharply increased the number of enforcement actions against such conduct."); Wayne, Inside Trading by Outsiders, N.Y. Times, May 27, 1984, \& F, at 1, 21 (commenting on Commission's willingness to "seek cases that have high publicity value."); Note, supra note 31, at 467 (commenting on the Commission's practice of prosecuting "high visibility cases to maximize the publicity and the resulting deterrence from eaeh case") (footnote omitted). 
the defendant's reputation is significant in an action under the ITSAindeed, more significant than in a private lawsuit in which punitive damages are imposed.

The second factor to be considered in determining the proper standard of proof is the risk of error created by the traditional procedurethat is, the risk of error created by the preponderance of the evidence standard-and the likelihood that a higher burden of proof would reduce that risk. ${ }^{214}$ According to the Court in Santosky, this inquiry focuses on whether the preponderance of the evidence standard "fairly allocates the risk of an erroneous factfinding between these two parties." 215

Several considerations are relevant to an analysis of this factor. First, the SEC and the typical defendant differ significantly in their ability to pursue the litigation. The SEC's litigation resources are not predetermined, while those of an individual defendant may well be. ${ }^{216}$

Second, while the Act directs judges to exercise discretion in establishing the actual amount of the penalty, it does not provide any guidelines for deciding when an amount less than the maximum penalty is appropriate. Because the SEC currently intends to seek the maximum penalty in most cases, ${ }^{217}$ there is a risk that the penalty imposed could be greater than the amount necessary for deterrence. ${ }^{218}$ Further, the Commission may use the threat of a treble damages penalty to induce the defendant to settle for an amount less than the maximum penalty; the lack of gnidelines for determining the penalty will make it more difficult for a defendant accurately to assess the risk that the maximum penalty will be imposed if the case proceeds to trial. ${ }^{219}$

Finally, the relative interests of the SEC and the defendant in avoiding an erroneous decision are not equal. The SEC's interest is limited to the enforcement of the securities laws in the particular case before the court. It does not gain financially from the penalty, nor is it entitled to

Santosky also considered significant the permanence of the loss. Of course, the ITSA's treble damages penalty entails a permanent loss of money. The stigma resulting from a judgment under the Act, however, may lessen over time. See Santosky, 455 U.S. at 753-54.

214. Santosky, 455 U.S. at 761-62.

215. Id. at 761.

216. The Santosky Court found relevant a discrepancy in parties' litigation resources. See id. at 763-64.

217. See HousE REPORT, supra note 31 , at $25 \mathrm{n} .48$ (memorandum accompanying letter of SEC Chairman Shad to Rep. Thomas P. O'Neill).

218. See Coffee, supra note 205, at 1158; Diver, supra note 20, at 1458. Diver argues that if the sanction is too low, illegitimate conduct will not be discouraged; if the sanction is too high, legitimate and beneficial conduct will be discouraged. "Only by reference to a set of standards can one determine whether a particular penalty is too low or too high." Id.

219. See infra notes 291-94 and accompanying text. 
the penalty. ${ }^{220}$ The defendant, in contrast, has an interest in avoiding payment of the penalty and avoiding the stigma that would result from the imposition of the penalty. Because the SEC has no corresponding interest in gaining the treble damages, the defendant's interests in avoiding an erroneous judgment outweigh those of the Commission. ${ }^{221}$

The final factor cited by Santosky as relevant to the burden of proof analysis adds only one element to those already considered. The court must weigh the government's interest in maintaining the preponderance of the evidence standard in cases under the ITSA. The SEC has argued that because in most of its cases against insider trading it must rely on circumstantial evidence for proof, a higher standard of proof would be an undue hardship. 222 This argument cannot pass muster. The nature of the evidence cannot dictate the standard of proof. In many cases in which the highest standard of proof applies, a criminal conviction rests solely upon circumstantial evidence. There is no evidence that the SEC's enforcement program would be impaired by a requirement that cases under the ITSA be proven by clear and convincing evidence.

The analysis above shows that courts should require an intermediate burden of proof before imposing the ITSA's treble damages penalty. ${ }^{223}$

220. The SEC might be considered to receive an indirect benefit if imposition of penalties in general deters future violations.

221. See Wheeler, supra note 204, at 292; see also Grass, The Penal Dimensions of Punitive Damages, 12 HAST. CONST. L.Q. 241, 263 (1985). The SEC can always fulfill its enforcement function by an action for injunctive relief and disgorgement, in which case the burden of proof will be a preponderance of the evidence. Thus, it has no legitimate interest in the penalty itself. Further, while the defendant does not have a more significant interest than does the SEC in the outcome of cases in which injunctive relief and disgorgement are sought, imposition of the penalty alters their relative positions.

222. See 1984 Senate Hearings, supra note 14, at $45-46$ (memorandum from office of the General Counsel to SEC Chairman Shad).

223. See Sales \& Cole, Punitive Damages: A Relic That Has Outlived Its Origins, 37 VAND. L. REv. 1117, 1166-67 (1984) (courts should require at least proof of "clear and convincing evidence" before assessing punitive damages). But see Herman \& MacLean v. Huddleston, 459 U.S. 375, 39091 (1983), in which the Supreme Court rejected the argument that in a private cause of action under section $10(b)$ the plaintiff must prove his case by a more than a preponderance of evidence, and United States v. Regan, 232 U.S. 37, 47-48 (1914), in which the Court held that even when the United States seeks to recover a penalty, only the preponderance of the evidence standard is applicable. Neither case, however, directly governs actions under the ITSA. The issue in Huddleston was the burden of proof that a private plaintiff must meet under section 10(b); and, generally, punitive damages have not been available under section $10(b)$ in actions brought by either a private plaintiff or the Commission. In Regan, the Court did not consider the possibility of an intermediate burden of proof, but chose only between the preponderance and the beyond a reasonable doubt standards. See Regan, 232 U.S. at 40.

There is some indication, however, that the Supreme Court considers a preponderance of the evidence to be the appropriate standard of proof in any case in which only money is at stake. See Huddleston, 459 U.S. at 387. But see Steadman v. SEC, 450 U.S. 91, 104-06 (1981) (Powell, J., dissenting) (asserting that securities industry professionals should be protected by intermediate burden of proof when the SEC imposes personal sanctions.) 
Such a standard would more appropriately allocate the risk of erroneous judgments between the SEC and the defendant, and it would reflect society's greater concern with imposition of a penalty than with remedies that merely put the parties near the positions they occupied before they violated the law. Thus, even though the preponderance of the evidence standard should apply when the Commission seeks only disgorgement, the imposition of a penalty changes the balance of the Santosky factors in favor of a higher standard. Moreover, the higher standard of proof would mitigate the problem of ambiguity in the law regulating insider trading by requiring clear evidence that the defendant's conduct encompassed each element of a Rule 10b-5 or 14e-3 violation. Finally, the clear and convincing standard would more certamly indicate the defendant's guilt of the alleged fraudulent conduct than would the preponderance standard, and this in turn would help guarantee that the penalty was reserved for those who were truly culpable and for whom the deterrent aspect of the ITSA would be appropriate. ${ }^{224}$

\section{E. Right to Jury Trial.}

Since the ITSA authorizes a penalty for violation of the insider trading laws, procedural protections should be afforded a defendant in addition to those granted in cases in which only disgorgement is sought. Additional procedures are necessary to ensure the guilt of the defendant before the penalty is assessed because of the defendant's right to avoid payment of the penalty and the stigma resulting from liability if his conduct was not intentionally unlawful. In addition to requiring the higher burden of proof, the Act should guarantee to the defendant the right to a trial by jury on the issue of liability for the treble damages penalty.

Congress did not specifically provide in the ITSA that a defendant has a right to demand a jury trial when the SEC seeks the treble damages penalty. ${ }^{225}$ The SEC argued against affording the right to a jury trial during the congressional hearings on the Act. It emphasized that juries would complicate and lengthen proceedings. ${ }^{226}$ These arguments are un-

224. See 1983 House Hearings, supra note 14, at 65 (comment of Rep. Wirth) ("[T]he preponderance of the evidence standard allows both parties to share the risk in roughly equal fashion. Any other standard expresses a preference for one side's interests."). In the context of imposition of a penalty, a preference should be expressed for the defendant. See infra notes 278-86 and accompanying text (discussing standard of culpability in an action under ITSA).

225. See 1983 House Hearings, supra note 14, at 46-47, 97-98, 153, 234, 248-49, 316-17 (discussing whether constitutional right to jury trial exists under ITSA); HouSE REPORT, supra note 31, at 16.

226. 1983 House Hearings, supra note 14, at 97 (letter from SEC Chairman Shad to Rep. Wirth) (“A statutory right to a jury trial could burden and prolong Commission actions for a penalty and complicate settlement negotiations. Moreover, the right to a jury trial in penalty actions may interfere with the successful prosecution of Commission injunctive proceedings."). 
persuasive. The presence of a jury in an action under the ITSA imposes no greater burden on the SEC than its presence under other statutory schemes imposes on other enforcing agencies. No court has cited this sort of burden as a ground for rejecting the defendant's claim to a jury trial. In fact, the seventh amendment and cases construing it suggest that the defendant should be entitled to demand a trial by jury in treble damages actions under the ITSA. ${ }^{227}$

Without an express guarantee in the Act of the right to a jury trial, the availability of a jury trial is determined by the seventh amendment. That amendment provides that "[i]n Suits at common law, where the value in controversy shall exceed twenty dollars, the right of trial by jury shall be preserved." 228 The key questions in applying the seventh amendment guarantee to an action by the SEC under the ITSA are, first, whether the action under the ITSA and the substantive provisions of the 1934 Act fall within the meaning of "Suits at common law," and, second, whether it makes any difference on the issue of the right to a jury trial that the plaintiff is the government.

The second question is more easily answered. In Atlas Roofing Co. v. Occupational Safety \& Health Review Commission, ${ }^{229}$ the Supreme Court specifically left open the issue whether the seventh amendment applies to government litigation. Nonetheless, many lower court cases have held that the seventh amendment guarantee applies when the government is the plaintiff and seeks to recover a fine or penalty. ${ }^{230}$ There is no

227. The amount of the penalty need not be determined by the jury. See United States v. J.B. Williams Co., 498 F.2d 414, 438 n.28 (2d Cir. 1974).

In cases that present difficult and complex issues of fact and law, as insider trading cases sometimes do, the use of a jury trial has been criticized. See, e.g., Devitt, Federal Civil Jury Trials Should Be Abolished, 60 A.B.A. J. 570 (1974); Landis, Jury Trials and the Delay of Justice, 56 A.B.A. J. 950 (1970); Redish, Seventh Amendment Right to Jury Trial: A Study in the Irrationality of Rational Decision Making, 70 Nw. U.L. REv. 486 (1975).

228. U.S. CONST. amend. VII. In criminal trials the sixth amendment governs the right to a jury trial. "In all criminal prosecutions, the accused shall enjoy the right to a speedy and public trial, by an impartial jury . . . ." U.S. CONST. amend. VI. See generally Higginbotham, Continuing the Dialogue: Civil Juries and the Allocation of Judicial Power, 56 TEx. L. REV. 47 (1977); James, Right to a Jury Trial in Civil Actions, 72 YALE L.J. 655 (1963); Shapiro \& Coquillette, The Fetish of Jury Trials in Civil Cases: A Comment on Rachel v. Hill, 85 HARv. L. Rev. 442 (1971); Note, An Examination of Due Process and Complex Exceptions to the Seventh Amendment: A Constitutional Ap. proach to the Right to Jury Trial in Complex Civil Litigation, 7 DEL. J. CORP. L. 134 (1982).

229. 430 U.S. 442,449 n.6 (1977).

230. See, e.g., United States v. Fred A. Arnold, Inc., 573 F.2d 605, 606 (9th Cir. 1978) (per curiam) (defendant entitled to trial by jury in suit by U.S. to collect withholding and F.I.C.A. taxes under Internal Revenue Code); United States v. J.B. Williams Co., 498 F.2d 414, 430 (2d Cir. 1974) (right to jury trial exists in government suit to collect civil penalties under Federal Trade Commission Act); United States v. ACB Sales \& Serv., Inc., 590 F. Supp. 561,569 (D. Ariz. 1984) (action for civil penalties under Federal Trade Commission Act includes right to trial by jury); Nuclear Regulatory Comm'n v. Radiation Technology, Inc., 519 F. Supp. 1266, 1278, 1286 (D.N.J. 1981) 
apparent reason for denying the seventh amendment guarantee simply because of the identity of the plaintiff. Therefore, until the Supreme Court decides otherwise, it must be assumed that the mere presence of the government as the plaintiff should not itself preclude application of the seventh amendment.

The harder question is whether an action for a penalty based on a violation of Rule $10 \mathrm{~b}-5$ or $14 \mathrm{e}-3$ is subject to the seventh amendment right to a jury trial as a "Suit at common law":

The phrase 'common law,' found in this clause, is used in contradistinction to equity, and admiralty, and maritime jurisprudence. . . . By common law, [the Framers of the Amendment] meant . . not merely suits, which the common law recognized among its old and settled proceedings, but suits in which legal rights were to be ascertained and determined, in contradistimction to those where equitable remedies were administered. ${ }^{231}$

An action for treble damages under the ITSA may also include requests for injunctive relief or disgorgement, remedies that traditionally have been administered by courts sitting in equity. ${ }^{232}$ But the action under the Act for a penalty resulting from a violation of the law more closely resembles an action to collect a debt, which is clearly legal in nature, than it does an action in equity. ${ }^{233}$

The Supreme Court has held that actions to enforce statutory rights generally are subject to the seventh amendment "if the statute creates legal rights and remedies, enforceable in an action for damages in the ordinary courts of law."234 Of course, Congress can choose to authorize the admimistrative agency, here, the SEC, to impose the penalty itself; in

(right to trial by jury in action to collect penalties for violation of Atomic Energy Act of 1954); United States v. Open Bulk Carriers, Ltd., 465 F. Supp. 159, 166 (S.D. Ga. 1979) (in government's suit for civil penalties under Shipping Act, defendants entitled to jury trial on material factual issues, including amount of penalty), aff'd, 727 F.2d 1061, 1062 (11th Cir. 1984); Mosley v. National Fin. Co., 440 F. Supp. 621, 622 (M.D.N.C. 1977) (private suit for civil penalty under Truth in Lending Act analogous to suits brought by U.S. to enforce same provision; therefore, right to jury trial exists).

231. Curtis v. Loether, 415 U.S. 189, 193 (1974) (emphasis in original) (quoting Parsons v. Bedford, 28 U.S. (3 Pet.) 433, 446 (1830)).

In arguing that an action to collect civil money penalties must be brought in a U.S. District Court, Professor Diver writes: "Such an action includes, of course, an opportunity for jury trial of contested factual issues not foreclosed by a previous binding judgment." Diver, supra note 20, at 1439 (footnote omitted).

232. See Porter v. Warner Co., 328 U.S. 395, 398-99 (1946) (holding that action for injunction and restitution, which is similar to disgorgement, is within court's equity jurisdiction).

233. See generally United States v. J.B. Williams Co., 498 F.2d 414, 422-24 (2d Cir. 1974) (statutory penalties have been held to trigger right to jury trial although statute is silent on the issue; statute can create action that is essentially legal).

234. Curtis v. Loether, 415 U.S. 189, 194 (1974) (action under section 812 of 1968 Civil Rights Act, 42 U.S.C. $\S 3612(1982)$ ). 
that case the administrative adjudication of guilt is not subject to a jury trial guarantee. ${ }^{235}$ But in the ITSA, Congress selected the district court rather than the SEC to impose the penalty. ${ }^{236}$

When the district court rather than the agency is assigned the adjudicative responsibility, however, and there is "obviously no functional justification for denying the jury trial right, a jury trial must be available if the action involves rights and remedies of the sort typically enforced in an action at law."237

The distinction between an action brought pursuant to the ITSA and any other case based on statutory rights is that the trial of an action under the ITSA may require the court to exercise its jurisdiction both in equity and at law. Consistent with principles of res judicata and collateral estoppel, a court's deternnination of the availability of equitable remedies-injunction and disgorgement-must follow trial to the jury of the action at law for penalties under the ITSA. ${ }^{238}$ But this requirement will not unduly complicate the case, and thus presents no justification for refusing to apply the seventh amendment. 239

\section{F. Unlimited Payments by the Defendant.}

In adopting the ITSA, Congress and the SEC sought to provide an additional deterrent against violations of the insider trading laws by rais-

235. See Atlas Roofing Co. v. Occupationál Safety \& Health Review Comm'n, 430 U.S. 442,450 (1977) (Congress may assign factfinding function and initial adjudication to administrative forum when "public rights" of statutory origin are litigated). But see Kirst, Administrative Penalties and the Civil Jury: The Supreme Court's Assault on the Seventh Amendment, 126 U. PA. L. Rev. 1281 (1978) (criticizing Atlas).

236. See ITSA $\S 2,15$ U.S.C. $\S 78 \mathrm{u}(\mathrm{d})(2)(A)$ (Supp. II 1984).

237. United States v. J.B. Williams Co., 498 F.2d 414, 424 (2d Cir. 1974) (quoting Curtis v. Loether, 415 U.S. 189, 195 (1974)).

238. See Beacon Theatres v. Westover, 359 U.S. 500, 508 (1959) (when actions of equity and law are joined in the same trial, parties are entitled to jury determination of all legal issues); see also Dairy Queen, Inc. v. Wood, 369 U.S. 469, 473 (1962) (legal issues, no matter how incidental to equitable issues in the same case, must be presented to the jury if properly demanded).

239. See Beacon Theatres v. Westover, 359 U.S. 500, 510-11 (1959) ("[O]nly under the most imperative circumstances . . . can the [seventh amendment] right to a jury trial of legal issues be lost through prior determination of equitable claims."). More generally, the Court has frequently construed the Constitution to compel additional procedural safeguards that protect individual rights, even though these safeguards also increase administrative burdens and complicate existing procedures. See, e.g., Baldwin v. State of New York, 399 U.S. 66, 73-74 (1970) (when possible penalty exceeds sixth months' imprisonment, right of criminal defendant to trial by jury is constitutionally guaranteed despite administrative inconvenience); Duncan v. Louisiana, 391 U.S. 145, 156-58 (1968) (same); see also Duren v. Missouri, 439 U.S. 357, $369-70$ (1964) (administrative convenience insufficient to justify automatic exclusion of women from juries); Schnieder v. Rusk, 377 U.S. 163, 167 (1964) (administrative convenience insufficient to justify statute's automatic deprivation of citizenship for those continuously residing abroad for three or more years). But cf. Little v. Streater, 452 U.S. 1,6 (1981) (determination of what procedures are sufficient to satisfy due process depends in part on fiscal and administrative burdens that additional procedural safeguards entail). 
ing the stakes for would-be lawbreakers, and the ITSA penalty clearly will help to accomplish this goal. But an inside trader, like anyone who violates the law, should be punished only for his "crime," and the punishment should appropriately reflect the harm done by the illegal act. In adding an element of deterrence to the existing sanctions for insider trading, Congress gave no guidance for determining how severe the total penalty imposed on an inside trader should be. Without such guidance, an inside trader could be penalized too severely, by being subjected to a variety of actions based on the same wrongful conduct. 240

The ITSA's treble damages penalty is not exclusive. ${ }^{241}$ Thus, in an enforcement action, the SEC could seek an injunction against future violations of the law, disgorgement, and the ITSA treble damages penalty, in effect forcing a defendant to pay out the profit gained or loss avoided four times. In addition, for the same conduct the Department of Justice could prosecute the defendant in a criminal action and obtam on conviction a maximum fine of $\$ 100,000 .{ }^{242}$ Furthermore, if the defendant's trading violated an obligation owed to private individuals, they could sue the defendant for compensatory damages under Rule $10 \mathrm{~b}-5$ or $14 \mathrm{e}-3 .{ }^{243}$ Thus, a person who violated the insider trading prohibitions might pay

240. See Easterbrook \& Fischel, Optimal Damages in Securities Cases, 52 U. CHI. L. REv. 611, 612 (1985).

241. See 1983 House Hearings, supra note 14, at 27-28, 56, 113 n.6, 151-52; supra note 80.

242. The 1934 Act, $\S 32,15$ U.S.C. $\S 78 f f$ (Supp. II 1984).

243. The amount of damages recoverable by private plaintiffs suing under Rule $10 \mathrm{~b}-5$ may be limited in one of two ways: first, by restricting the class of persons entitled to sue, Fridrich v. Bradford, 542 F.2d 307, 318 (6th Cir. 1976) (where defendant's trading did not affect the market price of the securities and thereby induce the plaintiff to buy, only persons who bought or sold the shares traded by the insider have standing under Rule 10b-5), cert. denied, 429 U.S. 1053 (1977); Wilson v. Comtech Telecommunications Corp., 648 F.2d 88, 94 (2d Cir. 1981) (duty to disclose or abstain from trading is owed only to those who trade contemporaneously with defendant-inside trader); or, second, by restricting the maximum recovery to the defendant's profits from the illegal trading, Elkind v. Liggett \& Myers, 635 F.2d 156, 173 (2d Cir. 1980); State Teachers Retirement Bd. v. Fluor Corp., 589 F. Supp. 1268, 1271 (S.D.N.Y. 1984). See generally Block \& Barton, Insider Trading-The Need For Legislation, 10 SEc. REg. L.J. 350, 357-62 (1983). In the event that the plaintiffs' damages exceed the defendant's profits, the plaintiffs would receive pro rata shares of the recovery. Elkind, 635 F.2d at 172. See Thompson, The Measure of Recovery Under Rule 10b-5: A Restitution Alternative to Tort Damages, 37 VAND. L. REV. 349, 396 (1984) (criticizing the disgorgement measure of damages as lacking deterrence); Note, Damages to Uninformed Traders for Insider Trading on Impersonal Exchanges, 74 CoLum. L. REv. 299, 314 (1974) (discussing problems of applying the proration rule). The disgorgement measure of damages used in Elkind may be greater than what is recovered in an enforcement action by the Commission. See SEC v. MacDonald, 699 F.2d 47, $52-54$ (1st Cir. 1983) (en banc).

Punitive damages generally have not been awarded under Rule 10b-5. Globus v. Law Research Serv., 418 F.2d 1276, 1283 (2d Cir. 1969), cert. denied, 397 U.S. 913 (1970); Green v. Wolf Corp., 406 F.2d 291, 303 (2d Cir. 1968), cert. denied, 395 U.S. 977 (1969). When the act that violates the federal securities laws also violates state law, courts have awarded punitive damages on the state law claim. Coffee v. Permian Corp., 474 F.2d 1040, 1044 (5th Cir.), cert. denied, 412 U.S. 920 (1973). 
out a sum that exceeds five times the profit made or loss avoided on the illegal trade. ${ }^{244}$

For several reasons, there should be a limit on the aggregate amount that a person who violates the insider trading prohibitions has to pay as a result of the same trading activity. First, fairness justifies some limit on a defendant's potential liability. The aggregate amount of the penalty imposed on a defendant under the ITSA and as a result of criminal prosecution should fit the crime. ${ }^{245}$ Second, the assessment of unreasonably large aggregate liability, once publicized, might discourage legitimate but novel conduct. Finally, unreasonably large aggregate liability unnecessarily emphasizes insider trading as a harmful activity over and above other equally pernicious conduct. ${ }^{246}$

One way to limit the aggregate sum for which a defendant is liable as a result of illegal trading or tipping is to condition imposition of the ITSA treble damages penalty on a consideration of the judgments resulting from other actions premised on the same conduct. ${ }^{247}$ This would encourage the SEC to consider the existence of other litigation against the defendant for the same conduct before it instituted an action under the ITSA. This, in turn, might lead to a more efficient allocation by the SEC of litigation and enforcement resources among all potential defendants.

\section{Is the ITSA a Criminal Statute IN Disguise?}

Because the ITSA permits the assessment of a money penalty that may exceed the criminal fine available in a particular criminal conviction for violation of the 1934 Act's insider trading prohibitions, the use of

244. An inside trader may pay out five times his profit gained or loss avoided through a combination of disgorgement (equal to profit or loss), the ITSA penalty (up to three times profit or loss), damages to private plaintiffs (up to profit or loss), and a criminal penalty of up to $\$ 100,000$ (likely to equal or exceed profit or loss). Damages to private litigants, however, are sometimes satisfied out of a fund created by disgorgement. See, e.g., SEC v. Golcanda Mining Co., 327 F. Supp. 257, 260 (S.D.N.Y. 1971).

245. Cf. Coffee, supra note 205 , at 1158 (discussing the problem of excess deterrence). It is anomalous that penalties for a civil violation of the 1934 Act can easily exceed the $\$ 100,000$ maximum criminal penalty for such violations. See 15 U.S.C. $\$ 78 \mathrm{ff}$ (Supp. II 1984) (maximum criminal penalty); see also Helvering v. Mitchell, 303 U.S. 391, 399-400 (1938) (penalty imposed under civil penalty statute was over thirty times maximum criminal fine applicable to same conduct).

246. Problems involving corporate financial disclosure and tender offers may be as serious as insider trading. See Klein, Outsider Proposes Changes in Insider Trading Bill, Legal Times of Washington, Dec. 12, 1983 ("[1]t is quite questionable whether, as the . . . [1TSA] implies, insider trading really can be said to be the most heinous securities law violation.").

247. Some civil penalty statutes impose "an upper limit on the amount of penalty per violation .. . [or] establish an upper limit on the total civil penalty liability that may be imposed for a related series of offenses." Diver, supra note 20, at 1441. This could have been done for the ITSA by placing a ceiling on the entire amount payable by a defendant as a result of his offense. 
civil procedures in cases assessing the treble damages remedy seems anomalous. ${ }^{248}$ Is the treble damages penalty really a criminal statute in disguise, requiring all of the constitutional guarantees afforded in any criminal proceeding? In light of the issues that the ITSA raises as a civil sanction, such as the definition of the prohibited activity and the requisite burden of proof, an interpretation of the statute as imposing a criminal sanction might lead to more acceptable results.

The traditional analysis of whether a penalty is criminal or civil begins with a great degree of deference to the label chosen by Congress. ${ }^{249}$ Courts afford substantial deference to Congress's choice of the civil or criminal label for a statute in the behef that Congress categorized the statute as it did after conscious, reasoned consideration of the nature of the penalty being imposed.

In enacting the ITSA, Congress did not address whether it should designate the treble damages penalty as a civil rather than a criminal sanction. It simply presumed the Act was an appropriate civil provision without analyzimg the issue. Congress's oversight is understandable considering that the ITSA was proposed, debated, and passed for the purpose of providing the SEC with a new weapon in its battle against insider trading. The SEC could use the sanction provided by the ITSA only if it was a civil sanction, since criminal prosecutions under the 1934 Act are not within the jurisdiction of the Commission. ${ }^{250}$ As a criminal provision, the ITSA would not assist the SEC's attempts to curb insider trading without also involving an increased effort on the part of the Justice Department. Since Congress made no focused inquiry into the character of the sanction before attaching a civil label to the ITSA, the civil label should not carry much weight in the consideration of the character of the statute.

In the absence of a clear enunciation by Congress, the courts have had difficulty in arriving at a logical analysis of the distinction between

248. But see Helvering v. Mitchell, 303 U.S. 391, 405 (1938), in which the Court held that a statute providing for a $50 \%$ penalty for fraudulent tax evasion was not a criminal statute. There, the penalty imposed under the civil penalty statute was $\$ 364,354.92$; for a willful violation of the tax laws, the maximum criminal fine that could be imposed was $\$ 10,000$. Id. at 395-96. In contrast, in One 1958 Plymouth Sedan v. Pennsylvania, 380 U.S. 693, 700-01 (1965), the Court considered it significant that forfeiture, the penalty under the civil statute at issue, could result in a greater burden on the defendant than that which would result from a criminal conviction based on the same conduct. See generally Levin, OSHA and the Sixth Amendment: When Is a "Civil" Penalty Criminal in Effect?, 5 Hastings CoNST. L.Q. 1013, 1046-54 (1978).

249. United States v. Ward, 448 U.S. 242, 248 (1980) ("First, we have set out to determine whether Congress, in establishing the penalizing mechanism, indicated either expressly or impliedly a preference for one label or the other.") (citation omitted).

250. The Department of Justice prosecutes criminal violations of the securities laws. 15 U.S.C. $\S 78 \mathrm{u}(\mathrm{d})(\mathrm{l}),(2)(1982)$. 
criminal and civil provisions. In part, the analysis and the answer to the question of appropriate classification depend on the purpose for which the question is asked. When the issue is the application of the double jeopardy clause of the fifth amendment or the procedural safeguards of the sixth amendment, the class of statutes that are labeled criminal and thus subject to those constitutional guarantees is narrower than when the issue is the applicability of the fifth amendment privilege against selfincrimination. ${ }^{251}$ Even beyond the confusion arising from classification based on purpose, however, the articulation of the distinguishing characteristics of a criminal sanction has been less than clear.

Case law suggests that the treble damages penalty of the ITSA does not render the Act a criminal provision for purposes of the double jeopardy clause or the sixth amendment trial protections. When defendants invoke these constitutional provisions, courts will ignore the legislature's labeling of a statute as civil only when sanctions under the statute involve imprisonment or some other substantial loss of liberty. Courts have not found the risk of loss of money, even with the attendant injury to reputation, sufficiently serious to reject Congress's choice of a civil enforcement mechanism for these purposes. ${ }^{252}$

Still, the ITSA might be considered a "quasi-criminal" statute, in which case defendants in actions brought by the SEC under the Act would be entitled to certain limited constitutional protections. ${ }^{253}$ Courts find a statute labeled civil by the legislature to be quasi-criminal if it im-

251. See generally Clark, Civil and Criminal Penalties and Forfeitures: A Framework for Constitutional Analysis, 60 MiNN. L. REv. 379, 382 (1976). Compare United States v. One Assortment of 89 Firearms, 465 U.S. 354, 366 (1984) (double jeopardy clause does not bar in rem forfeiture proceeding against firearms after gun owner has been acquitted on criminal charges involving the same firearms) and One Lot Emerald Cut Stones v. United States, 409 U.S. 232, 235-37 (1972) (per curiam) (acquittal of owner of jewels on criminal charges of willfully and knowingly smuggling articles into U.S. does not bar later forfeiture proceeding against jewels) with Kennedy v. MendozaMartinez, 372 U.S. 144, 184-86 (1963) (statutory revocation of citizenship held to be a criminal sanction).

252. See Clark, supra note 251, at 383 (Supreme Court will find statutes with severe sanctions to be criminal, regardless of legislative label; less severe sanctions, such as loss of money, do not justify ignoring statutory label). But see Chamey, The Need for Constitutional Protections for Defendants in Civil Penalty Cases, 59 CoRnell L. Rev. 478, 501-05 (1971) (discussing whether forfeitures arc criminal penalties for purposes of fourth and fifth amendments).

253. Among the constitutional protections that attach as a result of the "quasi-criminal" label are the fifth amendment privilege against self-incrimination, see, e.g., United States v. United States Coin \& Currency, 401 U.S. 715, 721-22 (1971), and the eighth amendment prohibition against cruel and unusual punishment, see, e.g., IVelsch v. Likins, 373 F. Supp. 487, 502-03 (D. Minn. 1974), affd, 525 F.2d 987 (8th Cir. 1975); Martarella v. Kelly, 349 F. Supp. 575, 585 (S.D.N.Y. 1972); sec also Clark, supra note 251, at 414-21; Sales \& Cole, supra note 223, at 1118 (labelling punitive damages "quasi-criminal fines"); Developments in the Law-Civil Commitment of the Mentally Ill, 87 HARV. L. REV. 1190, 1259-60 (1974). 
poses a punitive sanction. ${ }^{254}$ To determine whether the sanction is punitive or remedial, the courts generally analyze the legislature's purpose in adopting the statute and the effect of the sanction. If a defendant can show by "the clearest proof" that the purpose or effect of the statute is punitive, the court will reject the legislatively selected "civil" label.255

Congress clearly expressed its purpose in adopting the ITSA in the legislative history of the Act and in the statute itself. The legislative history demonstrates that Congress enacted the ITSA to increase deterrence of insider trading. ${ }^{256}$ During hearings held on the Act, commentators and members of Congress and of the SEC frequently stressed that the treble damages penalty was necessary to increase the burdens imposed for violating the insider trading laws. They believed that the penalty was necessary to deter would-be violators and punish the defendant. ${ }^{257}$ Moreover, the Act itself serves no purpose but to penalize a defendant for violating the law. Any amount received as a penalty must be paid into the Treasury; such amounts cannot be used to compensate victims of the defendant's conduct or to reimburse the SEC for the costs of the enforcement action. Therefore, the statute serves no compensatory purpose. The effect of the sanction is also clearly punitive. Courts may impose it even after the defendant has repaid the ill-gotten gains. ${ }^{258}$ The sanction serves only to punish a violator of the insider trading laws.

Another factor that courts sometimes consider in distinguishing civil non-punitive sanctions from quasi-criminal punitive ones is whether a finding of liability stigmatizes the defendant. ${ }^{259}$ Although the stigma

254. See United States v. United States Coin \& Currency, 401 U.S. 715, 718 (1971) (forfeiture is punitive in nature and therefore subject to fifth amendment protection against self-incrimination); United States v. Constantine, 296 U.S. 287, 294-96 (1935) (finding that special excise tax on retail liquor dealers was in fact a penalty, and on that basis holding tax unenforceable under tenth amendment after repeal of eighteenth amendment); Boyd v. United States, 116 U.S. 616, 634 (1886) (same as United Statcs Coin \& Currency); see also Clark, supra note 251, at 381.

255. United States v. One Assortment of 89 Firearms, 465 U.S. 354, 365 (1984) (quoting United States v. Ward, 448 U.S. 242, 249 (1980)); see Ball \& Friedman, The Usc of Criminal Sanctions in the Enforcement of Economic Legislation: A Sociological View, 17 STAN. L. REV. 197, 200, 211-12 (1965) (suggesting that one important characteristic of a criminal law is state's involvement in bringing action against wrongdoer; authors exclude from their definition of "crime" those statutes that impose only monetary fines.).

256. The 1TSA has as its purpose both general and specific deterrence. General deterrence is aimed at discouraging would-be violators; specific deterrence is concerned with the defendant in a particular case. On the purpose of the 1TSA generally, see 1983 House Hearings, supra note 14, at 23 (opening statement of Rep. Wirth).

257. See id. at 27 (statement of SEC Chairman Shad); id. at 12 (statement of Rep. Rinaldo); id. at 233-34 (statement of A.A. Sommer, Jr., former SEC Chairman).

258. See supra note 196 (citing cases discussing cumulative effects of criminal and civil actions based on the same conduct).

259. This consideration of stigma, suggested by Clark, supra note 251 , at $406-10$, is not very helpful as a distinguishing characteristic. It seems to put the cart before the horse. 
from payment of a monetary fine seems to be less than that which would result from imprisonment, any penalty indicates fault. Moreover, successful enforcement actions against inside traders have been increasingly publicized. Increased publicity adds to the reputational damage of a defendant found liable for insider trading under the ITSA. ${ }^{260}$

From these considerations, a court could conclude that the ITSA is a quasi-criminal penalty. ${ }^{261}$ This finding entitles the defendant to certain protections, such as the protection against self-incrimination of the fifth

No analysis of the nature of a statutory sanction would be complete without consideration of the factors enumerated by the Supreme Court for resolution of this issue in Kennedy v. MendozaMartinez, 372 U.S. 144 (1963). There, the Court reviewed a statute which authorized revocation of citizenship for draft evasion. Id. at $146-48,146 \mathrm{n} .1$. The Court hcld that the statute was criminal in nature, and, therefore, revocation of citizenship could not be accomplished without affording the defendant all of the constitutional protections normally available in criminal prosecutions. Id. at 165-67. In reaching its decision, the Court enumerated seven factors, which, it later declared, are "neither exhaustive nor dispositive," United States v. Ward, 448 U.S. 242, 249 (1980), to help in an analysis of the civil or criminal nature of a statute:

Whether the sanction involves an affirmative disability or restraint, whether it has historically been regarded as a punishment, whether it comes into play only on a finding of scienter, whether its operation will promote the traditional aims of punishment-retribution and deterrence, whether the behavior to which it applies is already a crime, whether an alternative purpose to which it may rationally be connected is assignable for it, and whether it appears excessive in relation to the alternative purpose assigned are all relevant to the inquiry, and may often point in differing directions.

Kennedy, 372 U.S. at $168-69$ (footnotes omitted).

Of these factors, several are relevant to the analysis of the ITSA's penalty of treble damages, but none is determinative. First, the treble damages penalty does impose an "affirmative disability or restraint" on persons who have violated the insider trading laws. The ITSA punishes persons found to have engaged in insider trading because of their illegal conduct. See Grass, supra note 221, at 248 . 55 (analyzing what this factor means). The third Kennedy factor, requiring a finding of scienter, is also relevant to the penal character of the ITSA. The underlying violation of the insider trading laws is conditioned upon a finding of scienter. See supra note 127. Further, while the statute instructs the judge in his discretion to set the amount of the penalty by considering all relevant circumstances, it does not enumerate any circumstances, such as good faith, as meriting particular attention. This factor, too, indicates that the ITSA imposes a criminal sanction. See Grass, supra notc 221, at 274 75. In addition, operation of the ITSA will further one of the traditional aims of punishment; the sole purpose for its adoption was to promote deterrence. See supra notes 256-57 and accompanying text. Further, the behavior to which that statute applies is already a crime under section 32 of the 1934 Act, but such conduct also subjects the defendant to civil liability in many instances. Thus, this factor seems to carry no significant weight either way. See Grass, supra note 221, at 289-96. The "alternative purpose" issue is not relevant here, because there is no purpose for the treble damages penalty aside from deterrence. The only conceivable purpose for the ITSA aside from deterrence would be to compensate the SEC for its expenses in investigating the violation and conducting the litigation. See Grass, supra note 221, at 300-05. Congress did not, however, indicate that it intended the ITSA to serve such a compensatory purpose, and if such a goal had been intended, the penalties recoverable under the ITSA should have been payable to the Commission rather than to the Treasury. See generally Grass, supra note 221 (analyzing each of the Kennedy factors with respect to the penal nature of punitive damages).

260. See supra notes 207-13 and accompanying text.

261. Cf. Sedima, S.P.R.L. v. Imrex Co., 105 S. Ct. 3275, 3282-84 (1985) (discussing possibility that an action under the Racketeer Influenced and Corrupt Organizations Act, 18 U.S.C. $\$ 1$ 1964(c), is quasi-criminal). 
amendment. 262 The quasi-criminal label, however, does not require application of the trial procedures embodied in the sixth amendment, nor does it prevent duplicate prosecutions based on the same conduct, as prohibited by the double jeopardy clause. ${ }^{263}$ Thus, the conclusion that the treble damages penalty is punitive has limited practical significance for a defendant in an action brought pursuant to the ITSA. It does not require a standard of proof higher than the preponderance of the evidence standard, nor does it guarantee a right to jury trial or a more definite statement of the boundaries of illegality. ${ }^{264}$

Even if the ITSA were construed as a criminal statute, doubts exist whether criminal enforcement is the most effective way to change economic behavior, and insider trading in particular. First, criminal sanctions for insider trading clearly provide an ancillary enforcement mechanism. "[I]mplicit in the legislative scheme [of economic regulations employing criminal sanctions] is the conception of the criminal sanction as a last resort to be used selectively and discriminatingly when other sanctions fail."265 In addition to the legislative scheme, the fact that criminal prosecutions are carried out by the Department of Justice rather than the SEC reinforces their ancillary role. Any increase in enforcement efforts by the SEC will not necessarily affect the use of criminal laws in enforcement.266 Thus, unless the means of invoking the criminal process change, use of a criminal sanction will not achieve the deterrent purpose of the new Act.

Second, there seems to be less public outrage against insider trading than against other, more traditional forms of criminal conduct. This lack of public condemnation is due in part to disagreement among lawyers

262. See, e.g., Boyd v. United States, 116 U.S. 616, 637-38 (1886).

263. See, e.g., United States v. One Assortment of 89 Firearms, 465 U.S. 354, 366 (1984) (double jeopardy clause does not apply to forfeiture proceedings brought after acquittal on criminal charges of dealing in firearms without a license); McKeiver v. Pennsylvania, 403 U.S. 528, 545-51 (1971) (jury trial not required in juvenile delinquency proceedings, even though punitive in nature); Helvering v. Mitchell, 303 U.S. 391, 399 (1938) (double jeopardy clause does not bar action to recover penalty for fraudulent avoidance of income tax, brought after defendant was acquitted of criminal charges of tax evasion); Compton v. United States, 377 F.2d 408, 411 (8th Cir. 1967) (standard of proof in forfeiture proceeding is preponderance of the evidence). See generally Comment, The Concept of Punitive Legislation and the Sixth Amendment: A New Look at Kennedy v. Mendoza-Martinez, 32 U. CHI. L. REV. 290 (1965).

264. The right to a jury trial in criminal cases is governed by the sixth amendment, and the right does not attach to prosecutions for petty offenses. See Baldwin v. New York, 399 U.S. 66, 68 (1970); W. LaFave \& J. IsRael, Criminal Procedure § 21.1(b), at 826-28 (1984).

265. Kadish, supra note 126 , at 424,426 (general discussion of the use of criminal sanctions as part of "a considered economic policy").

266. See supra notes 75-77 and accompanying text; 1983 House Hearings, supra note 14, at 70-71 (statement of John Fedders) (predicting that criminal prosecutions may decrease as use of treble damages penalty increases). 
and business persons over the basic soundness of laws prohibiting insider trading. ${ }^{267}$ Especially when the insider trading does not injure any identifiable person, as is true in most misappropriation cases, the courts are often reluctant to promote aggressive enforcement of the law through criminal sanctions. When the proscribed conduct does not incite the public's moral outrage, one should question whether criminal sanctions are appropriate. ${ }^{268}$ Regulation through civil enforcement mechanisms may provide the better answer. ${ }^{269}$

\section{Recommended Guidelines for Civil Penalties}

The conclusion that the criminal law is not necessarily the appropriate or most efficient method for regulating insider trading brings us back to the concerns about the ITSA's effect as a civil sanction. ${ }^{270}$ These concerns-about the definition of the prohibited conduct, the appropriate burden of proof, the right to a jury trial, and the total penalty imposed on a defendant-arise because the treble damages penalty is a dramatic departure from the traditional approach to enforcing the securities laws. When a penalty is imposed, the interests at stake between the enforcer and the defendant differ from those at stake when the remedy merely restores the pre-violation status. The Commission has no right to the penalty; in fact, the penalty will not directly benefit the SEC. On the other hand, the defendant has a legitimate, significant interest in avoiding payment of the penalty if it would not serve the deterrent purpose of the ITSA. Moreover, the defendant has a right to protect his reputation from undeserved injury and himself from the additional liability of a

267. See, e.g., H. MANne, Insider Trading ANd the Stock Market 1-15, 182 (1966) (insider trading causes no significant injury to corporate investors and is the most appropriate device for compensating entrepreneurs in large corporations); Carlton \& Fischel, The Regulation of Insider Trading, 35 STAN. L. REv. 857, 866-72 (1983) (allowing insider trading may benefit firms by inducing managers to behave in less risk-averse manner); Dooley, supra note 20, at 3, 47-55 (insider trading regulation only justified if investors are primary beneficiaries of the regulation); Manne, Eeonomic Aspects of Required Disclosure Under Federal Securities Laws, in WaLL STREeT IN TRANSition: The Emerging System and its Impact on the Economy 21 (N.Y.U. C. Bus. \& Pub. Admin. 1974); Manne, Insider Trading and the Law Professors, 23 VAND. L. REv. 547, 588-89 (1970) (arguing against prohibition of insider trading); $c f$. Heller, Chiarella, SEC Rule l4e-3 and Dirks: "Fairness" versus Economic Theory, 37 Bus. LAw. 517, 556-58 (1982) (arguing that it is economically sound to prohibit use of nonpublic "market" information by investors, but that prohibition on use of inside information should be maintained on basis of moral obligation of fiduciaries to deal fairly with their beneficiaries).

268. See generally Kadish, supra note 126, at 435-37, who argues that since society tends to trcat "business crimes" lightly, lack of notice that insider trading sanctions were to be strictly applied would result in unfairness initially. Professor Kadish excludes from his discussion, however, conduct that amounts to fraud, which is in fact the basis of an action under Rule 10b-5. See supra notes 100-21 and accompanying text (regarding fraud and the misappropriation theory).

269. Sec Goldschmid, supra note 44 , at 917-18.

270. See supra notes 83-195 and accompanying text. 
treble damages award. It is because of the penalty authorized by the ITSA, and the resulting interests of the defendant, that greater protections are warranted.

To ensure that the sanction is used only when appropriate and with the necessary protections, I propose the following guidelines for application of the Act. These guidelines would give notice to the public of when, why, and to what end the SEC will seek the treble damages penalty, and could be adopted either by Congress as a supplement to the ITSA or by the Commission pursuant to its rulemaking authority. The adoption and publication of these guidelines would serve several functions. First, standards governing when the Commission could invoke the Act and how large a penalty it could seek would teduce the transaction costs of negotiating a settlement of the case. By considering these guidelines, the defendant could more easily evaluate the risks of settlement and trial. 271 Second, the SEC would have greater influence over a trial court's exercise of discretion in fixing the amount of the penalty if the SEC based the sanction it proposed on a published set of criteria. Without a published set of guidelines governing the amount of the penalty, the court could not easily determine whether the SEC's proposal was based on rational considerations and was consistent with its treatment of other defendants in similar cases.272 Furthermore, some of the suggested guidelines would help traders determine in advance whether their conduct violated the ITSA. Although the guidelines do not specifically define insider trading, they do propose a new standard of scienter. Finally, the establishment of standards for invoking the ITSA and fixing the penalty would facilitate the necessary oversight of the Commission's use of the sanction by Congress, the courts, and the public. ${ }^{273}$

271. When an agency attempts to compromise a penalty claim-regardless of the source of its authority - it should not permit itself to ignore underlying regulatory objectives; a mitigation requested or a compromise offered should be acceptable to the agency only because payment of that particular sum furthers statutory goais, not simply because the violator is willing to pay it. Without having first articulated those goals and translated them into operative standards, the agency can never make that judgment.

Diver, supra note 20, at 1459; see also Note, supra note 31 , at $488-89$.

272. [B]y establishing standards for assessing or compromising penalties recoverable in a civil action, the agency may well be able to influence the courts in the exercise of their penalty-setting discretion. A penalty structure developed and articulated by the agency responsible for the initiation of enforcement action can make a legitimate claim to at least some deference by a judge.

Diver, supra note 20, at 1459 (footnote omitted).

273. Id. at 1460 ("Finally, the establishment of standards is necessary to facilitate oversight of the penalty negotiation process by agency management, the executive, Congress, and the general public.") (footnote omitted). 


\section{A. When to Invoke the ITSA.}

Guidelines should clarify when the SEC would invoke the ITSA in an enforcement proceeding. ${ }^{274}$ Such guidelines might include a list of factors that the Commission would consider in deciding whether to seek the civil penalty. The Commission could consider, for example, whether the defendant's conduct seriously injured the investing public or, where the misappropriation theory was invoked, whether the defendant's conduct had a significant impact on the market. The existence of an injury would be one factor weighing in favor of the application of the ITSA.275 The Commission should also consider whether the defendant previously violated the insider trading or other securities laws. Multiple violations by a defendant indicate a need for greater deterrence in his case, and the treble damages penalty would work toward that end.

Another factor the Commission should weigh in deciding whether to seek the ITSA penalty is the defendant's degree of culpability. Although liability under the ITSA depends on an underlying violation of Rule $10 \mathrm{~b}-5$ or $14 \mathrm{e}-3$, which require a showing of scienter or recklessness, ${ }^{276}$ this showing may not demonstrate culpability warranting the treble damages penalty. It establishes only that the defendant knew the nonpublic nature of the information and intended to trade on the basis of it.277 Such proof would not itself constitute sufficient culpability if the defendant reasonably believed that he was not an insider, did not acquire the information from an insider, or had no relationship to other investors sufficient to give rise to the duty to disclose the information or abstain from trading.

Considering the impact on the defendant of treble damages liability under the ITSA, perhaps some standard of culpability higher than scienter or recklessness ought to be required before a defendant is penalized for violating the law. In part, this would help insure against any unfairness that may result from a change in the legal theory underlying insider trading liability. In addition, it would recognize the quasi-criminal nature of the penalty, in contrast to the civil remedies of disgorgement and

274. The fact that many agencies retain a broad range of charging discretion not subject to judicial interference does not mean that the agency should not make some effort to structure that discretion. The choice of which offenses to prosecute can have significant impact on the fairness and the effectiveness of the regulatory program. For the same reasons that agencies should set and publicize standards for determining penalty amounts, agencies should attempt to formulate standards governing the decision to prosecute.

Id. at 1480 (footnote omitted); see also Diver, The Optimal Precision of Administrative Rules, 93 YALE L.J. 65 (1983) (discussing benefits and disadvantages of specificity in rulemaking).

275. But cf. infra note 292 and accompanying text (discussing effect that recovery by private litigants should have on amount of penalty).

276. See supra notes $127-33$ and accompanying text.

277. See supra notes 131,133 and accompanying text. 
compensatory damages. ${ }^{278}$

One might look to the standard of culpability required in a criminal prosecution for insider trading for guidance here, since the penalty of the ITSA resembles a criminal fine in some respects. ${ }^{279}$ Under section 32 of the 1934 Act, a criminal conviction for violation of section $10(\mathrm{~b})$ requires proof that the defendant "willfully" violated the statute. ${ }^{280}$ The term "willfully" suggests that something above the traditional scienter requirement in civil actions has to be shown to satisfy the statute. Interestingly, however, courts have interpreted the term "willfully," as used in section 32 , to mean that only ordinary scienter is necessary to support a criminal conviction. ${ }^{281}$ In part because section 32 was drafted before section $10(\mathrm{~b})$ was interpreted to require a showing of scienter, the courts have not considered the possible anomaly that the same degree of culpability applies in both criminal actions under section 32 and civil actions. ${ }^{282}$

278. See supra notes $253-64$ and accompanying text.

279. See supra notes $248-69$ and accompanying text.

280. Section 32(a) of the 1934 Act provides:

Any person who willfully violates any provision of this chapter . . . shall upon conviction be fined not more than $\$ 100,000$, or imprisoned not more than five years, or both; . . . but no person shall be subject to imprisonment under this section for the violation of any rule or regulation if he proves that he had no knowledge of such rule or regulation.

15 U.S.C. $\S 78 f$ (a) (Supp. II 1984) (emphasis added).

281. Although it appears that no courts interpreting section 32(a) have addressed the meaning of the term "willfully" in that provision, the meaning of the term has been addressed in similar contexts. See, e.g., Hinkle Northwest, Inc. v. SEC, 641 F.2d 1304, 1307-08 (9th Cir. 1981) (action to review SEC order suspending petitioners from association with any broker-dealer for willfully violating record-keeping requirement of section 17(a) of the 1934 Act). The court in Hinkle Northwest inferred willfulness from petitioners' inaction coupled with their expertise in the securities industry. Id. at 1308; see also Decker v. SEC, 631 F.2d 1380, 1386-87 (10th Cir. 1980) (appeal from SEC order censuring petitioner for aiding and abetting violation of section 17(e) of Investment Company Act of $1940,15$ U.S.C. $\$ 80 \mathrm{a}-17(\mathrm{e})(1)(1982))$. The censure in Decker was imposed pursuant to section 203(e)(5) of the Investment Advisers Act, 15 U.S.C. $\S 80 \mathrm{~b}-3(\mathrm{e})(5)(1982)$, which requires a finding that the person acted willfully before a sanction may be imposed. Id. "The term 'willfully' has been held in similar contexts to mean merely intentionally committing the act which constitutes the violation. There is no requirement that the actor also be aware that he is violating one of the Rules or Acts.' Tager v. SEC, 344 F.2d 5, 8 (2d Cir. 1965)." Decker, 631 F.2d at 1386. Nees v. SEC, 414 F.2d 211, 221 (9th Cir. 1969), reviewed an appeal from an SEC order barring petitioners from association with broker-dealers for willfully violating section 17(a) of the Securities Act of 1933 and section 15(c)(1) of the 1934 Act. The Court said that a willful violation meant "only that the act was a conscious, intentional action." Nees, 414 F.2d at 221. Further support for the conclusion that willfulness does not require cognizance that the act violates the law is found in section 32(a) itself, which provides that "no person shall be subject to imprisonment under this section for the violation of any rule or regulation if he proves that he had no knowledge of such rule or regulation." IS U.S.C. $\S 78 \mathrm{ff}($ a) (Supp. II 1984) (emphasis added).

282. The legislative history of section 32 supports the courts' interpretations that the "willful" standard means no more than scienter-i.e., an intent to deceive. See Hearing of the Comm. on Interstate and Foreign Commerce of the House of Representatives on H.R. 7852, 73rd Cong., 2d Sess. 113 (1934), reprinted in 8 I. Ellenberger \& E. MAHAR, LEGISLATIVE HISTORY OF THE SECURI- 
Of course, the ITSA could be interpreted to require something in addition to scienter, for example, a showing that the defendant not only knew the nonpublic nature of the information and intended to trade on the basis of it - the traditional scienter requirements ${ }^{283}$ - but also believed that his conduct was illegal. This requirement would be particularly helpful in cases involving conduct the illegality of which was unsettled. ${ }^{284}$ Where the boundaries of the prohibited conduct are unclear, the law should be careful to penalize, by civil or criminal sanctions, only on a showing that the defendant's conduct has been clearly established by the courts to be illegal and that the defendant believed the conduct was illegal. ${ }^{285}$ Otherwise, imposition of the penalty does not further the specific deterrence goal, since the threat of a penalty cannot deter those who do not and should nat be expected to know that their conduct violates the law. ${ }^{286}$ Thus, to trigger application of the ITSA, the guidelines should require an element of culpability in addition to those that underlie violations of the substantive provisions of the 1934 Act.

Finally, the guidelines should provide that the SEC would not invoke the ITSA when relying on a novel theory of liability. Unforeseeable developments $i m$ the conceptual underpinnings of the law regulating insider trading should not be used to penalize conduct which previously was not clearly proscribed. ${ }^{287}$

TIES ACT OF 1933 AND SÉCURITIES EXCHANGE ACT OF 1934, at 113 (1973); FRIEDMAN, supra note 9, at 83-92 (discussing state-of-mind requirements for criminal prosecutions in securities cases); Herlands, Criminal Law Aspects of the Securities Exchange Act of 1934, 21 VA. L. REV. 139, 146.49 (1934) (contrasting willfulness with "willful and knowing" requirement in section 32(a) governing false filings; author concludes that willfulness means only that defendant realized he was acting in wrongful manner, and not that defendant was aware of statute or rule that was violated by his conduct); Mathews, Criminal Prosecutions Under the Federal Securities Laws and Related Statutes: The Nature and Development of SEC Criminal Cases, 39 GEO. WASH. L. REV. 901, 956-58, 958 n.339 (1971) (same).

283. See supra notes $127-30$ and áccompanying text.

284. See Kadish, supra note 126, at 428-29 (allowing defense that the defendant "could not reasonably" have known that his acts fell within scope of the law would remedy problem of vague. ness in the substantive prohibition).

285. See United States v. Wịnston, 558 F.2d 105, 108 (2d Cir. 1977). Winston reviewed a criminal action for violation of section 2 of the Railway Labor Act, 45 U.S.C. $§ 152$ (1982), which prohibits willfully infiuencing or coercing employees in relation to unionization. In reversing for prejudicial error in the jury instruction on what satisfies the element of "willfulness," the court said that willfulness means "the defendant's conduct must constitute a 'voluntary, intentional violation of a known legal duty.' [Umited States v. Pomponio, 429 U.S. 10, 12 (1976)]." Winston, 558 F.2d at 108. The court rejected a jury instruction providing that "the defendants were not required to know that their conduct violated the Railway Labor Act or any other law." Id. at 107; see also Sales \& Cole, supra note 223, at $1130 \mathrm{n} .78$ (awards of punitive damages are generally conditioned upon finding of conscious wrongdoing).

286. See supra notes $157-89$ and accompanying text.

287. In the first case in which the ITSA was invoked, the SEC brought an enforcement action against Federico Ablan, Cesar Duque, and two corporations controlled by Ablan. SEC v. Ablan, 


\section{B. Amount of the Penalty.}

Congress left the exact amount of the penalty imposed under the ITSA to the discretion of the district court. ${ }^{288}$ The SEC proposes an amount (generally, the maximum), ${ }^{289}$ and the judge must determine whether that or another sum is appropriate. In exercising this discretion, the trial judge should consider a number of factors, including, but not limited to, those discussed below, ${ }^{290}$ which might also properly be considered by the Commission in deciding how large a penalty to seek. ${ }^{291}$

No. 84-8532 (S.D.N.Y. July 23, 1985), reported in part in [1984-1985 Transfer Binder] FED. SEC. L. REP.(CCH) 1] 91,847 (reporting filing of action Nov. 27, 1984); [1984-1985 Transfer Binder] FED. SEC. L. REP. (CCH) I 92,209 (reporting entry of judgment July 23, 1985); see also 16 SEC. REG. \& L. REP. (BNA) 1915 (Dec. 7, 1984) (summarizing factual background of case). The Commission claimed that Ablan and Duque violated Rule 10b-5 by purchasing shares in Monchik-Weber Corp. based on nonpublic information that Monchik-Weber was going to be acquired by McGraw-Hill. See 16 SEc. REg. \& L. REP. (BNA) at 1915. The information about the acquisition was revealed to Ablan and Duque by Leonardo Siguion-Reyna, who was introduced to management of MonchikWeber by Ablan and who ultimately became a shareholder and director of Monchik-Weber. See id. at 1916. Ablan and Duque acted as agents for Siguion-Reyna in his discussions with MonchikWeber about a Philippine joint venture. See id. Through these discussions and others between Ablan and Duque and Siguion-Reyna after the latter became a director of Monchik-Weber, Ablan and Duque were informed of the proposed acquisition by McGraw-Hill. See id.

The SEC based its case against Ablan and Duque on the "temporary insider" theory espoused in Dirks v. SEC, 463 U.S. 646, 655 n.14 (1983). See 16 SEC. REg. \& L. REP. (BNA) at 1915-16. It argued that Ablan and Duque became temporary insiders when they received word of the proposed acquisition from Monchik-Weber's chief executive officer, who told them of it to explain its effect on the proposed Philippine joint venture. See id.

A consent decree was entered in Ablan on July 23, 1985, which ordered Ablan to disgorge $\$ 138,889$ and pay a penalty pursuant to the ITSA of $\$ 69,737$. The penalty equals the profit made by Ablan on trades executed after the effective date of the ITSA. SEC v. Ablan, [1984-1985 Transfer Binder] FED. SEC. L. REP. (CCH) I 92,209 (S.D.N.Y. July 23, 1985).

The allegations against Ablan and Duque did not present a new or unique theory of liability under Rule 10b-5. See 16 SEC. REG. \& L. REP. (BNA) at 1915-16; see also SEC v. Gaffney, [19841985 Transfer Binder] FED. SEC. L. REP. (CCH) \ 92,002 (S.D.N.Y. Apr. 18, 1985). In Gaffiney the court entered a consent decree in which penalties were imposed under the ITSA for tipping and trading on the basis of material nonpublic information about an impending merger. [1984-1985 Transfer Binder] FED. SEC. L. REP. (CCH) at 90,962. The tipper-insider was required to pay a penalty even though he did not trade; a penalty was also assessed against the tippee-traders. Id. The penalty imposed on the tippee-traders amounted to less than the amounts disgorged. Id. The penalty imposed on Gaffney, the tipper-insider, was less than that assessed against either of the tippeetraders. Id.

288. ITSA § 2, 15 U.S.C. $\S 78 u$ (d)(2)(A) (Supp. II 1984).

289. See 1983 House Hearings, supra note 14, at 44; see also Langevoort, supra note 31 , at 1278 79 (suggesting that when defendant is a "sophisticated trader," maximum penalty is appropriate).

290. Cf. Diver, supra note 20 , at 1501 ("To some extent, high penalty amounts necessarily imply a greater need to individualize since the higher the potential penalty, the greater the range of potential motivational impact."). Diver suggests that the following factors should be considered in setting the amount of the penalty for an individual defendant: ability to pay (i.e., chance of collection), culpability, and the harm to the public resulting from the defendant's activity. See id. at 1461-72. See generally Goldschmid, supra note 44, at 946-47.

291. In some cases, it might be most efficient if the SEC sought the maximum penalty under the ITSA, in order to get the defendant to take the case seriously and answer quickly. Requesting the 
First, and perhaps most important, the court considering an ITSA penalty should take into account those amounts the defendant is likely to pay in other actions based on the same conduct. Although Congress did not prescribe a maximum amount for liability resulting from one or a series of related transactions violating the insider trading laws, some sort of maximum penalty, above compensatory damages, is appropriate. ${ }^{292}$

Other factors relevant to the determination of the amount of the penalty include the defendant's ability to pay the penalty; ${ }^{293}$ the effect of the defendant's conduct on the members of the investing public and on the market generally; the defendant's culpability; the defendant's prior securities law violations; and, in certain cases, the existence of public outrage over the defendant's conduct. This last factor is significant for defendants who occupy positions of public trust and confidence at the time they violate the law. ${ }^{294}$

\section{Procedural Protections for the Defendant.}

Greater procedural protections should be provided defendants when a penalty is sought than when only disgorgement or compensatory damages are at issue. The SEC should be required to prove liability and the appropriateness of the penalty by clear and convincing evidence, ${ }^{295}$ and such liability should not be imposed for challenged conduct that did not violate previously articulated standards of legality.296 Further, courts should reserve the penalty for defendants who violate the law with the

maximum penalty also would put the SEC in a good bargaining position by enabling it to offer a reduction in the penalty if the case is settled.

On the other hand, initially requesting the maximum penalty may increase the transaction costs of the settlement process by inducing the defendant to prepare a vigorous defense. See Diver, supra note 20 , at 1483.

292. Cf. Diver, supra note 20 , at $1440-41$.

293. The court should assess the impact of the penalty on the defendant's financial condition; the penalty should not cause bankruptcy. Cf. In re Nelson Ghun \& Assocs., 2 COMm. FUT. L. Rep. (CCH) II 22,255A at 29,341 (CFTC July 5, 1984) (calculation of civil penalties should take into account likelihood of collection; "timely collection of civil penalties is as much of a deterrent to misconduct as their imposition").

294. The cases brought against Thomas Reed, formerly a member of the National Security Council, for insider trading in Amax options based on nonpublic information about the Amax-Socal merger illustrate a situation in which the identity and position of the defendant incite public outrage at his conduct. See 1983 House Hearings, supra note 14, at 67-70; The SEC's Investigation of Thomas Reed: Hearing before the Subcomm. on Securities of the Senate Comm. on Banking, Housing, and Urban Affairs, 98th Cong., 1st Sess. 1 (1983); see also United States v. Reed, 601 F. Supp. 685 (S.D.N.Y.) (criminal prosecution), rev'd, 773 F.2d 477 (2d Cir. 1985); SEC v. Reed, 97 F.R.D. 746 (S.D.N.Y. 1983) (seller of stock options not entitled to intervene); O'Connor \& Assocs. v. Dean Witter Reynolds, Inc., 529 F. Supp. 1179 (S.D.N.Y. 1981) (private action arising out of Reed's trading).

295. See supra notes $190-224$ and accompanying text.

296. See supra notes 97-189 and accompanying text. 
belief that their conduct is illegal, so that only those whose conduct reaches a high level of culpability would be penalized. ${ }^{297}$ And, finally, the defendant should have the right to a trial by jury on the issue of liability under the ITSA. 298 These limitations on the use of the treble damages penalty would not unduly inhibit the SEC's prosecution of illegitimate conduct, but they would protect from unanticipated consequences those whose conduct does not warrant penalization.

\section{CONCLUSION}

Congress could have enhanced deterrence against insider trading in several ways. It could have strengthened the criminal enforcement of insider trading violations, authorized the SEC to impose administrative sanctions for such conduct, broadened and specified the conduct to be prohibited, or authorized additional sanctions for imposition in a civil enforcement proceeding. Each of these actions would have had some effect, and a combination of some or all of them would have placed inside traders on the top of Congress's "most wanted" list. In choosing the last alternative by adopting the ITSA, Congress sought to add a remedy-a weapon, as it were-without changing the substantive law defining unlawful insider trading. Congress decided to leave the substantive law of insider trading untouched for many reasons, among which were the desire for quick passage of the ITSA and the difficulty of adjusting the definition of insider trading in a way that would help enforcement efforts.

The use of a penalty, however, creates problems that were not present when the only result of an enforcement action was to restore defendants to the positions they occupied before violating the law. These new problems arise primarily because the underlying substantive law of insider trading lacks clarity, and because the absence of a definite, bright line dividing legal from illegal behavior, coupled with the use of a quasicriminal sanction, raises concerns about fairness and about protecting defendants from unwarranted threats and imposition of liability. This article has sought to develop solutions to these problems by recommending guidelines. These guidelines would be most effective if adopted by the SEC or Congress. Uniform guidelines would foreclose the possibility that every case brought by the Commission would require a constitutional analysis of the Act. The guidelines are intended to preserve the Act's goal of deterrence and, at the same time, to protect the interests of defendants and potential defendants.

297. See supra notes $278-86$ and accompanying text.

298. See supra notes $225-38$ and accompanying text. 